\title{
Beef heifer growth and reproductive performance responses following two levels of fall stockpiled forage allocation
}

\author{
Bobbi Lynn Bailey
}

Follow this and additional works at: https://researchrepository.wvu.edu/etd

\section{Recommended Citation}

Bailey, Bobbi Lynn, "Beef heifer growth and reproductive performance responses following two levels of fall stockpiled forage allocation" (2013). Graduate Theses, Dissertations, and Problem Reports. 5141. https://researchrepository.wvu.edu/etd/5141

This Dissertation is protected by copyright and/or related rights. It has been brought to you by the The Research Repository @ WVU with permission from the rights-holder(s). You are free to use this Dissertation in any way that is permitted by the copyright and related rights legislation that applies to your use. For other uses you must obtain permission from the rights-holder(s) directly, unless additional rights are indicated by a Creative Commons license in the record and/ or on the work itself. This Dissertation has been accepted for inclusion in WVU Graduate Theses, Dissertations, and Problem Reports collection by an authorized administrator of The Research Repository @ WVU. For more information, please contact researchrepository@mail.wvu.edu. 


\title{
BEEF HEIFER GROWTH AND REPRODUCTIVE PERFORMANCE RESPONSES FOLLOWING TWO LEVELS OF STOCKPILED FALL FORAGE ALLOCATION
}

\author{
Bobbi Lynn Bailey \\ Dissertation submitted to the Davis College of Agriculture, Natural Resources and Design \\ at West Virginia University in partial fulfillment of the \\ requirements for the degree of \\ Doctor of Philosophy \\ in \\ Animal and Food Sciences \\ K. Marie Krause, Ph.D., Chair \\ Edward B. Rayburn, Ph.D. \\ Matthew E. Wilson, Ph.D. \\ Eugene E. Felton, Ph.D. \\ Thomas C. Griggs, Ph.D.
}

Division of Animal and Nutritional Sciences

Morgantown, West Virginia

2013

Keywords: heifers, stockpiled forage, grazing, growth, reproductive performance 


\section{All rights reserved}

\section{INFORMATION TO ALL USERS}

The quality of this reproduction is dependent upon the quality of the copy submitted.

In the unlikely event that the author did not send a complete manuscript and there are missing pages, these will be noted. Also, if material had to be removed, a note will indicate the deletion.

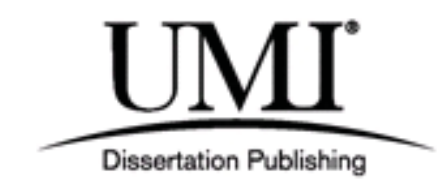

UMI 3576311

Published by ProQuest LLC (2013). Copyright in the Dissertation held by the Author.

Microform Edition @ ProQuest LLC.

All rights reserved. This work is protected against unauthorized copying under Title 17, United States Code

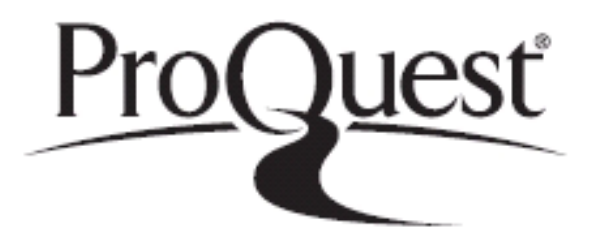

ProQuest LLC.

789 East Eisenhower Parkway

P.O. Box 1346

Ann Arbor, Ml 48106 - 1346 


\title{
ABSTRACT \\ Beef heifer growth and reproductive performance responses following two levels of fall stockpiled forage allocation
}

\author{
Bobbi Lynn Bailey
}

Increasing costs of feeds have prompted producers to consider heifer development systems utilizing low-cost/low-input feedstuffs including extended-season grazing utilizing stockpiled forage. Feed resources used in developing replacement females are a major factor influencing cost of production (Freetly et al., 2001; Clark et al., 2005). Recent research on heifer development systems has been conducted primarily in dry-lot settings and limited information exists comparing systems which utilize standing forage (Larson and Funston, 2011). Forage systems in Appalachia are based on cool season grasses such as tall fescue, orchardgrass, white clover, and red clover. Stockpiling of forages during late summer and fall for grazing has been shown to be an effective practice to extend the grazing season and reduce the amount of stored feeds needed (Allen et al, 1992; Kallenbach et al., 2003b). Among the species used for stockpiling, the most commonly studied is tall fescue. Research has demonstrated that tall fescue has the ability to maintain quality throughout the fall and early winter better than other grasses. Less is known about the stockpiling characteristics of other grasses and legumes, especially naturalized pastures containing complex mixtures. Therefore, specific objectives of the research presented here include: 1) comparing heifer growth and reproductive performance in response to two levels of stockpiled fall forage allocation: daily herbage DM allocation of 3.5 (LO) or 7.0 (HI) \% of BW; and 2) assessing the seasonal dynamics of forage quality, herbage mass, and botanical composition of naturalized pastures containing mixed cool-season species in response to two different fall stocking rates (HI vs LO). Treatments were replicated 3 times per year for 3 years (2009-2012). There were no treatment effects for changes in botanical composition. There was no significant effect of year on percentage of total grass species in the pasture; however, $\%$ grass tended to decrease over the 3-year period from $70 \%$ to $45 \%(P=0.10)$ while total legume percentage increased from $6 \%$ to $31 \%(P<0.05)$. There was a significant treatment $\mathrm{x}$ year $(P<$ $0.01)$ and year $x$ sampling period interaction $(P<0.05)$ for herbage mass. In years 1 and 2 , herbage mass declined steadily in both HI and LO treatments. From early in the fall grazing period to the middle of the period herbage mass declined $9.1 \%$ and $8.6 \%$ (year 1 ) and $10.4 \%$ and $7.0 \%$ (year 2) for LO and HI treatments, respectively. From the middle of the fall grazing period to late in the period, herbage mass declined $10.0 \%$ and $8.5 \%$ (year 1 ) and $9.7 \%$ and $8.9 \%$ (year 2) for LO and HI treatments, respectively. In year 3, however, herbage mass declined at a much faster rate than in years 1 and 2 from early in the fall period to the middle portion of the period ( $15.2 \%$ for both LO and HI treatments). This rapid decline in year 3 is most likely due to the high percentage of legumes present. There was no treatment effect, but there was a significant year effect $(P=0.05)$ for $\mathrm{CP} \%$ during the fall grazing period. Mean CP \% was 15.8\% (year 1), $19.4 \%$ (year 2,) and 17.0\% (year 3). Throughout the fall grazing period, $\mathrm{CP}$ declined in both treatments from $18.3 \%$ (early grazing) to $18.1 \%$ (mid grazing) and $16.2 \%$ (late grazing) $(P=$ $0.003)$. There was a significant year effect $(P<0.001)$ and there tended to be a treatment effect $(P=0.06)$ for NDF. NDF increased from the beginning of treatment initiation to late into fall grazing and there was a significant year $\mathrm{x}$ sampling period interaction for $\operatorname{NDF}(P=0.002)$. 
There was no treatment, year, or treatment $x$ year interaction effects for IVTDMD. There was a significant year $\mathrm{x}$ sampling period interaction $(P=0.009)$ for IVTDMD and it declined throughout the fall grazing period, $81.9 \%, 79.4 \%$, and $75.4 \%$ for early, middle, and late portions of the grazing period. Nutritive content of the pastures was adequate to meet the requirements of beef heifers. Heifers in the LO group gained $0.12 \mathrm{~kg} / \mathrm{d}$ whereas heifers in the HI group gained $0.40 \mathrm{~kg} / \mathrm{d}$ during the fall grazing period $(P<0.0001)$. Fall ADG was affected by NDF content of the pasture; for each 1 percentage unit increase in NDF, fall ADG decreased $0.14 \mathrm{~kg}(P<0.05)$. During winter feeding, ADG was $0.30 \mathrm{~kg} / \mathrm{d}$ and $0.39 \mathrm{~kg} / \mathrm{d}$ for LO vs HI heifers, respectively $(P<$ 0.001). During the spring grazing period, LO heifers had numerically higher ADG than HI heifers (1.38 vs. $1.30 \mathrm{~kg} / \mathrm{d} ; P=0.64)$. Hip height ( 122.7 vs. $121.4 \mathrm{~cm} ; P<0.01)$, BCS (5.8 vs $5.6 ; P<0.01)$, and BW (356 vs. $335 \mathrm{~kg} ; P<0.0001)$ at the end of spring grazing was higher for HI heifers than LO heifers. Heifers in the LO group compensated with greater summer ADG than heifers in the HI group $(0.74$ vs. $0.66 \mathrm{~kg} / \mathrm{d} ; P<0.05)$. Total ADG from treatment initiation (November) through pregnancy diagnosis (August) was higher for HI heifers than LO heifers $(0.61$ vs. $0.55 \mathrm{~kg} / \mathrm{d} ; P<0.001)$ as was BW at pregnancy diagnosis $(415 \mathrm{vs} .402 \mathrm{~kg} ; P<0.01)$. Percentage of heifers reaching puberty by the time of AI was $34 \%$ for both groups $(P=0.93)$. Percentage of heifers becoming pregnant to AI tended $(P=0.13)$ to be higher for HI heifers $(44 \%)$ than for LO heifers $(32 \%)$. Fall ADG across treatment groups affected the probability of a heifer becoming pregnant by AI $(P<0.05)$. The probability of a heifer becoming pregnant by AI with ADG in the fall of $0 \mathrm{~kg}, 0.5 \mathrm{~kg}$, and $1.0 \mathrm{~kg}$ is $29 \%, 46 \%$, and $64 \%$, respectively. Percentage pregnant to the bull (61\% for LO vs. 59\% for HI; $P=0.80)$ and final pregnancy rate $(74 \%$ for LO vs. $77 \%$ for HI; $P=0.61$ ) was similar for the two groups. We interpret these results to indicate that: 1) mixed cool-season naturalized pastures can be effectively stockpiled for fall and winter grazing; and 2) delaying the majority of weight gain until late in heifer development can decrease costs of winter feeding and potentially result in adequate overall pregnancy rates. 


\section{TABLE OF CONTENTS}

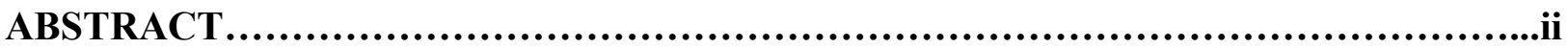

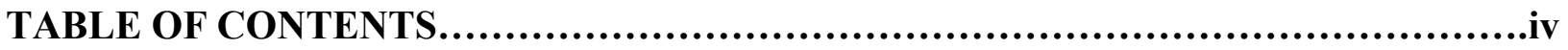

LIST OF FIGURES ..........................................................................

LIST OF TABLES.....................................................................viii

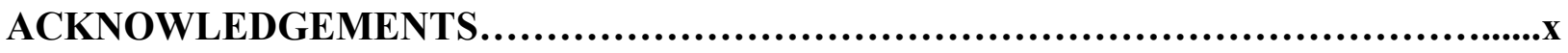

CHAPTER 1 - Introduction and Literature Review..........................................1

Introduction, Research Justification, and Objectives...................................2

Literature Review.....................................................................6

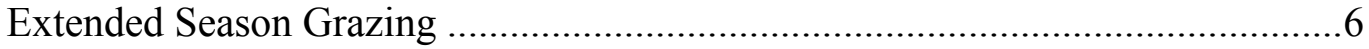

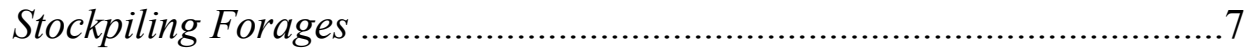

Suitable Forage Species .................................................8

Length of Accumulation Period ......................................... 12

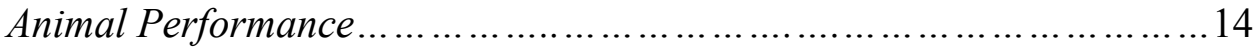

Induction of Puberty................................................... 16

Hormonal Regulation..............................................16

Factors Affecting Onset of Puberty....................................... 18

Body Weight..................................................... 18

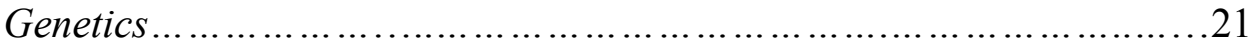

Photoperiod and Season of Birth ..................................22

Compensatory Growth.....................................................23

Nutrient Restriction Period ........................................23

Realimentation Period ...............................................26

Factors Affecting Compensatory Growth ...........................27

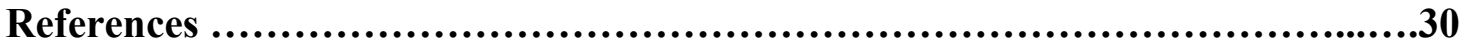

CHAPTER 2 - Herbage mass, forage quality, and botanical composition of mixed cool season naturalized pastures in response to two fall stocking rates....41

Abstract.............................................................................42

Introduction..........................................................................43

Pasture and Treatments..........................................................43

Forage Measurements...................................................................45

Statistical Analysis..................................................................46

Evaluation of nutritive value, herbage mass, and botanical composition of

pastures.......................................................................................47

Botanical Composition................................................47

Herbage Mass ...........................................................48

Forage Nutritive Value of Pastures .......................................49

Summary and Conclusions...........................................................51

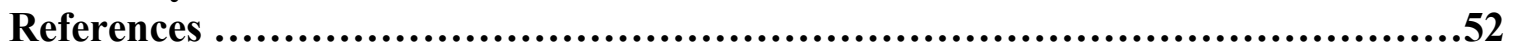


CHAPTER 3 - Beef heifer growth and reproductive performance responses following two levels of stockpiled fall forage allocation .................................64

Abstract.........................................................................65

Introduction............................................................................67

Materials and Methods.................................................................68

Experimental Procedures.................................................68

Forage Mass Determination................................................69

Botanical Composition of Pastures....................................... 70

Forage Nutritive Analysis . .......................................... 70

Animal Measurements ................................................ 73

Determination of Puberty .............................................. 74

Synchronization and Breeding Protocol ...................................... 74

Statistical Analysis..................................................... 75

Results and Discussion...........................................................75

Climatological Data..................................................... 75

Botanical Composition ................................................... 76

Herbage Mass ..................................................... 77

Forage Quality ........................................................ 77

Heifer Performance: Growth............................................ 78

Heifer Performance: Reproduction....................................8 81

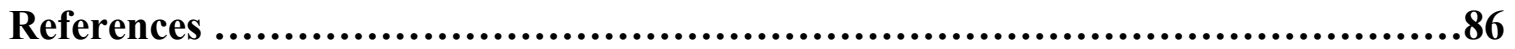

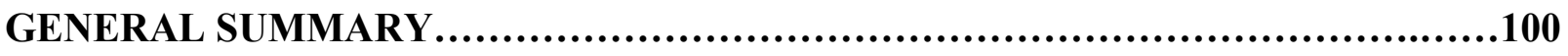

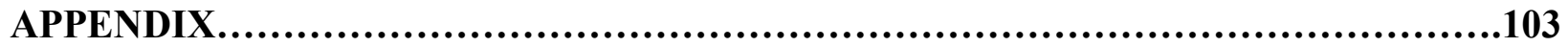




\section{LIST OF FIGURES}

\section{Chapter 1}

Figure 1. Endocrine and ovarian changes associated with puberty onset in the heifer and factors affecting interval to puberty onset

Figure 2. Schematic representation of compensatory gain in relation to ADG and animal BW..29

\section{Chapter 2}

Figure 1. Mean herbage mass throughout the fall grazing periods for yr 1-3.

Figure 2. Herbage mass decline during the fall grazing period for HI and LO treatments and for yr $1-3$.

Figure 3. Decline in crude protein (CP) throughout the fall grazing period...................61

Figure 4. Increase in neutral detergent fiber (NDF) throughout the fall grazing period.

Figure 5. Decline in in vitro true dry matter digestibility (IVTDMD) throughout the fall grazing period.

\section{Chapter 3}

Figure 1. Growth patterns (ADG) of LO and HI heifers during the fall, winter, spring and summer

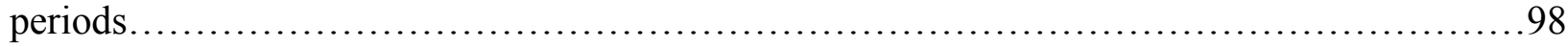

Figure 2. The predicted probability of heifers becoming pregnant to AI based on fall ADG.....99

\section{Appendix}

Figure 1. Snowfall amounts (2009-2012). 104

Figure 2. Rainfall amounts (2009-2012).

Figure 3. Average Temperature (2009-2012). .106

Figure 4. Changes in percent red and white clover concentrations in HI and LO treatments for yr 1-3 ( $\mathrm{LO}=$ daily pasture $\mathrm{DM}$ allowance of $3.5 \%$ of $\mathrm{BW}, \mathrm{HI}=$ daily pasture allowance of $7.0 \%$ of $\mathrm{BW})$.

Figure 5. Percent non-legume forbs in HI and LO pasture treatments for yr 1-3 (LO = daily pasture DM allowance of $3.5 \%$ of $\mathrm{BW}, \mathrm{HI}$ - daily pasture allowance of $7.0 \%$ of $\mathrm{BW}$ ). 
Figure 6. Percent legumes in HI and LO pasture treatments for yr 1-3 (LO = daily pasture DM allowance of $3.5 \%$ of $\mathrm{BW}, \mathrm{HI}=$ daily pasture allowance of $7.0 \%$ of $\mathrm{BW}) \ldots \ldots \ldots \ldots \ldots \ldots \ldots \ldots \ldots \ldots$

Figure 7. Percent grass in HI and LO pasture treatments for yr 1-3 ( $\mathrm{LO}=$ daily pasture DM allowance of $3.5 \%$ of $\mathrm{BW}, \mathrm{HI}=$ daily pasture allowance of $7.0 \%$ of $\mathrm{BW}$ )

Figure 8. Heifer ADG for $\mathrm{HI}$ and LO treatment groups during the fall, winter, spring and summer periods ( $\mathrm{LO}=$ daily pasture $\mathrm{DM}$ allowance of $3.5 \%$ of $\mathrm{BW}, \mathrm{HI}=$ daily pasture allowance of $7.0 \%$ of $\mathrm{BW}$ ) 


\section{LIST OF TABLES}

\section{Chapter 2}

Table 1. Regression equations developed relating clipped forage samples with rising plate meter readings for the fall grazing period

Table 2. Percentage of grass, legume and non-legume forbs in LO and HI treatment areas for $\mathrm{yr}$

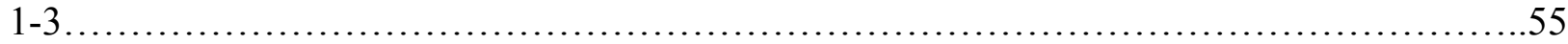

Table 3. Botanical composition (\% of DM) of pastures 2009-2012 ..........................56

Table 4. Long-term monthly mean rainfall, snowfall and temperature, and departures from the

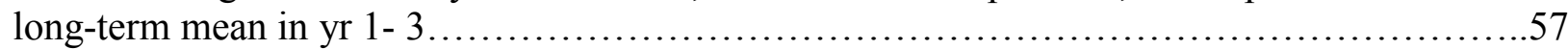

Table 5. Nutritional composition of pastures during the fall grazing period.................................58

\section{Chapter 3}

Table 1. Regression equations developed relating clipped forage samples with rising plate meter readings for the fall, spring and summer periods

Table 2. Heifer descriptive statistics pooled across years...................................91

Table 3. Long-term monthly mean rainfall, snowfall and temperature, and departures from the

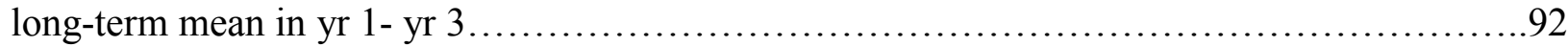

Table 4. Mean herbage mass ( \pm SD) throughout the fall, spring and summer grazing periods...93

Table 5. Mean nutritional composition ( $\pm \mathrm{SD}$ ) of pastures during the fall, spring, and summer periods.

Table 6. Mean nutritional composition $( \pm \mathrm{SD})$ of pastures, haylage and soy hulls...............95

Table 7. Effects of fall forage allocation (HI vs LO) and period on heifer BW gain and BW .....96

Table 8. Effects of fall forage allocation (HI vs LO) on heifer reproduction.

\section{Appendix}

Table 1. Long-term monthly mean rainfall, snowfall and temperature, and departures from the

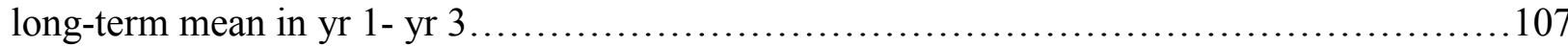

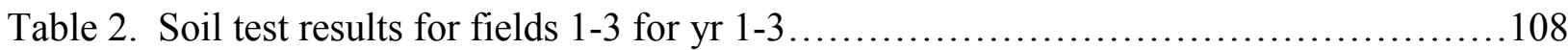


Table 3. Nutritional composition of pastures, haylage and soy hulls...................................113

Table 4. Heifer descriptive statistics pooled across years............................... 114

Table 5. The effect of pasture allowance on fertility response to timed AI and subsequent

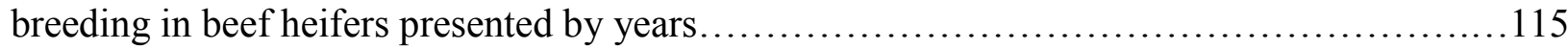




\section{ACKNOWLEDGEMENTS}

I would like to take this opportunity to extend a special thanks to Dr. Krause and my committee members, Dr. Rayburn, Dr. Griggs, Dr. Felton, and Dr. Wilson for their guidance and the opportunities they have provided me throughout my graduate career. I would also like to thank Dr. Dailey, Dr. Inskeep, and Dr. Lewis for their insight and assistance with my research project.

Additionally, Mark Satterfield, Research Assistant and several former and current undergraduate and graduate students deserve a heartfelt thank you for their contributions toward the completion of my program. These include: Josh Peplowski, Kristen Moran, Lisa Tager, Jennie Zambito, Caleb Lemley, Hari Vommi, and Caleb Griffin. They spent countless hours in the lab and out in the field taking forage samples, putting up fence, and collecting data on the animals.

I would like to express my gratitude to Rodney Keyser and the staff of the West Virginia University Reedsville Experiment Station. Without their assistance, this project would have been impossible to achieve. I would also like to thank Ms. Tammy Webster and her staff in the West Virginia University Rumen Fermentation Profile Lab. Tammy was a great resource, providing guidance and expertise when greatly needed. I am also thankful for their assistance in helping me to complete my lab work. For help with the statistical analysis of my data, I would like to thank Dr. Claudia Leonardi and Dr. Phil Turk. 


\section{CHAPTER 1}

\section{Introduction and Literature Review}




\section{INTRODUCTION, RESEARCH JUSTIFICATION, AND OBJECTIVES}

The current U.S. beef production system has evolved away from totally forage-based production systems to one that is heavily dependent on grains as the major feedstuff. High fuel costs have resulted in the use of alternative energy sources such as utilizing grain to produce ethanol which has in turn resulted in high grain prices. This situation poses a great challenge to producers due to the high cost of fuel and the continuous search for alternative energy. These factors have led to an increase of over $\$ 29.6$ billion dollars in the annual cost of livestock production since 2010 (USDA-NASS, 2012). Feed accounted for the largest expenditure (17.1\%) and also had the largest dollar increase per farm, up 21.4\% since 2010. As input costs in beef production continue to rise, it becomes increasingly important to minimize the costs of producing a marketable animal or animal product. Approximately $70-75 \%$ of the total energy requirements for beef production is used for maintenance (Ferrell and Jenkins, 1985). In addition, the cow herd uses an estimated $65-75 \%$ of the total energy required in a beef operation (Klosterman and Parker, 1976). Therefore, about $50 \%$ of the total energy required for beef production is used for the maintenance of breeding females.

In Appalachia, grassland is an extensive natural resource and is ideally suited for grassland based beef production (Scaglia et al., 2008). In West Virginia (WV) and Virginia (VA) some 3.7 million acres are in pasture (USDA Economic Research Service 2012). Most small farms in Appalachia are livestock operations which depend upon commodity markets to sell their livestock. Pasture-raised beef offers producers a potential niche market, premium prices and higher profits. The ability to meet the nutritional needs of grazing cattle through their entire developmental period, 12 months a year with minimal or no dependence upon stored feed 
or supplements is the biggest challenge. Reducing the use and dependence on conserved forages can reduce the cost of rearing replacement heifers and at the same time make the final product conform better to the label "Pasture Raised Beef".

Feed resources used in developing replacement females are a major factor influencing cost of production (Freetly et al., 2001; Clark et al., 2005). During the last several decades, systems for post-weaning development of replacement heifers have primarily focused on feeding heifers to achieve or exceed a specified target weight, expected to maximize heifer pregnancy rates. Significant changes in the economy and cattle genetics have occurred over this time, which indicates that these intensive systems should be re-evaluated. They may maximize pregnancy rates, but not necessarily improve profit or sustainability. These intensive heifer development systems require large investments in equipment and facilities, and significant use of fossil fuels and cereal grains.

Due to growing demand for human food and ethanol production, the sustainability of systems which utilize cereal grains as a source of energy in heifer diets may be diminished (Funston et al., 2009). Because cereal grain production requires significant fossil fuel-based inputs, beef production practices must incorporate more forage harvested by grazing beef cattle to become sustainable. Maximizing forage use by the grazing animal is a key way to reduce production costs. Since well-managed pasture provides forage for only about one-half to onethird the cost of producing harvested feeds, extending the grazing season by stockpiling forage for fall and winter grazing is one of the most effective ways to reduce costs (Rayburn, 2000). Extending the grazing season can reduce labor, machinery and storage costs of making harvested forage, and still meet replacement heifer target performance levels. 
Extended-season grazing has many challenges including seasonal variation in pasture growth rate, pasture forage quality relative to livestock requirements, the need for pasture area reserved for stockpiled forage, and accessibility of forage during the grazing period when there is dense or icy snow layers. Accessibility, or amount of forage dry matter (DM) that animals have the opportunity to ingest, is an important factor in animal performance and can be limiting during the growing season as well the dormant season. An additional management challenge with extended-season grazing is achieving adequate winter growth rates in livestock for which there is a performance target, such as spring-born heifers that must reach an adequate size and weight at breeding.

Development of replacement heifers at optimal rates of growth that promote puberty before breeding is critical for beef cattle production. Age at puberty is a major determinant of lifetime reproductive efficiency of beef cows and nutritional status is one of the more welldefined variables that influence the onset of puberty (Schillo et al., 1992). One of the goals of most beef cattle operations is to develop replacement heifers to conceive at 14-16 months of age and calve at approximately 2 years of age. Heifers that conceive early in their first calving season wean more and heavier calves during their lives (Lesmeister et al., 1973). Heifers should experience two or three estrous cycles before onset of the breeding season because the fertility of the first estrus is lower than that of subsequent estrous periods (Byerley et al., 1987). Development of replacement heifers during the post-weaning to pre-breeding period greatly impacts when puberty, pregnancy, and parturition will occur. Management during the pasture stockpiling, grazing, and subsequent winter hay-feeding periods, along with quality and amount of winter hay and winter weather conditions, are therefore critical to reproductive performance of heifers in extended-season grazing programs. 
Forage availability is frequently a limiting factor during fall/winter grazing systems. Previous research has shown that cattle with restricted access to forage early in the winter exhibit substantial compensatory gain when abundant forage allowed ad-libitum is available in the spring (Roberts et al., 2009; Funston and Larson, 2011; Mulliniks et al., 2012). Therefore, restricting forage allowance during the fall/winter period has the potential to stretch limited, high quality forage resources further without depressing animal performance. Recent research on heifer development systems has been conducted primarily in dry-lot settings and limited information exists comparing systems which utilize standing forage (Larson and Funston, 2011).

Thus, the focus of this research project is to address some of the challenges of extending the pasture grazing season into winter while meeting target performance levels for replacement beef heifers.

Therefore, specific objectives of the research presented here include:

1. Comparing heifer growth and reproductive performance in response to two levels of stockpiled fall forage allocation: high herbage DM allocation (7\% of BW) vs. low herbage DM allocation (3.5\% of BW).

2. Assessing the seasonal dynamics of forage quality, herbage mass, and botanical composition of naturalized pastures containing mixed cool-season species in response to two different fall stocking rates. 


\section{LITERATURE REVIEW}

\section{EXTENDED-SEASON GRAZING}

The Appalachian mountains contain one of the largest forage resources in the United States. Pastures in this region are usually located on steep, rough terrain in land classes VI and VII. Beef cattle production systems in this region utilize naturalized grasslands, mainly comprised of Kentucky bluegrass, orchardgrass, and tall fescue, with some white and red clover (D'Souza et al., 1990). Feed, especially winter feed, represents over half of the cost of producing livestock (Rayburn, 2000). In northern Appalachia, the winter period can last up to six months, and usually requires the feeding of conserved forages to livestock (Prigge et al., 1999) and this has been traditionally accomplished through the use of harvested feed. However, small profit margins in animal production systems have highlighted the need for more extensive use of pastures by livestock producers. One possibility to reduce the need for harvested forage and associated costs, is extended grazing on permanent pastures and aftermath hayfields (D’Souza et al., 1990).

Extending the grazing season by using stockpiled forage in late fall and during the winter months has been shown to be a very economical way to maintain livestock profitability. Stockpiling forage is accomplished by allowing forage to accumulate in late summer for use in fall and winter (Hall and Jung, 1993). Extending the grazing season by using stockpiled perennial forages in the fall and winter reduces the amounts of hay required for winter feeding of beef cattle (Hitz and Russell, 1998). It has been demonstrated that stockpiling forage is economically beneficial to the producer (Van Keuren, 1970; Willms et al., 1993). Adequate yield and nutrition levels for various classes of livestock can also be maintained (Jensen et al., 2002; Riesterer et al., 2000). Producing and storing winter feed is one of the largest expenses 
incurred by the producer and is usually the most labor-intensive practice. Stockpiling forage can lengthen the grazing season and reduce the labor needed to winter beef cows by as much as $25 \%$ (Van Keuren, 1970). Grazing stockpiled forages during late autumn and early winter has been shown to reduce costs by approximately $\$ 47$ per cow per year (Wolf et al., 2003).

The quality of stockpiled forages is determined by multiple factors, including plant species, climate, accumulation period, and fertilization timing and rate. Furthermore, in order for winter pasture programs to be successful, it may be necessary to utilize rotational or strip grazing in order to reduce trampling and wasting of forages by the animals.

\section{Stockpiling Forages}

Stockpiling of forages during late summer and fall for grazing has been shown to be an effective practice to reduce the amount of stored feeds needed (Allen et al, 1992; Kallenbach et al., 2003b). Initial work on winter grazing of forages was conducted by British researchers in the late 1930's. These studies showed that winter grazing, under certain conditions, was possible and that at least part of the nutritional needs of livestock could be met by grass (Griffith and Hutton, 1936; Davies and Fagan, 1938). Later, in 1962, Cowling determined that forage yield during the winter depends greatly on weather conditions during the summer and fall seasons and can therefore vary significantly from year to year. He also noted that weathering contributes to some loss of DM in fall stockpiled forage; however, it is not high when compared with losses occurring in other methods of conservation such as ensiling. Baker et al. (1965) concluded that grain supplements would be needed to maintain livestock performance if animals were forced to utilize winter forage more efficiently because there was a greater amount of forage wasted by livestock when grazing fall pasture than when grazing at other times. On the other hand, 
Hammes (1976) showed that animals grazing stockpiled forage performed as well as those on conventional hay feeding programs.

\section{Suitable Forage Species}

Selecting plant species with proper characteristics for successful fall and winter grazing has the potential to maximize livestock benefit. Forage species adapted to stockpiling include perennials such as tall fescue (Schedonorus phoenix), orchardgrass (Dactyalis glomerata) and companion perennial legumes; winter annual grasses such as rye (Lolium multiflorum) and wheat (Triticum aestivum); and annual forbs such as brassicas (Rayburn, 2000). The most commonly studied forage for stockpiling is tall fescue. During fall, tall fescue has been shown to yield more dry matter than other cool-season grasses including Kentucky bluegrass (Poa pratensis L.), orchardgrass, and reed canarygrass (Phalaris arundinacea) (Archer and Decker, 1977; Taylor and Templeton, 1976). Tall fescue dominates forage systems in a region ranging from central Oklahoma to central North Carolina and from northern Alabama to Kentucky, covering more than 15 million hectares (Bouton and Hopkins, 2003). Tall fescue is also widespread in the northwestern United States, where it is grown for seed production and is adapted to many temperate regions across the world (Hannaway et al., 2009).

Tall fescue grows well under a variety of soil and climatic conditions, including semiwet, and both acidic and alkaline soils (Bagley et al., 1983; Martin and Leonard, 1967). Tall fescue is more drought and frost tolerant than other forage species, and will maintain itself under limited fertility conditions (Hall, 1994d; Barnes et al., 2003). It can withstand closer grazing than some other grasses and is more tolerant of continuous stocking (Barnes et al., 2003; Hall and Jung, 1993). The forage produced by tall fescue during the winter is of a higher quality than during the summer; it contains lower levels of indigestible fiber (Fales 1986). Tall fescue is 
typically infected with an endophyte, Neotyphodium coenophialum, which produces toxic alkaloids. These alkaloids are deleterious to animal performance. Concentrations of the endophyte are significantly lower during the winter versus summer (Ju et al. 2006).

In West Virginia, Collins and Balasko (1981b) reported that tall fescue stores large amounts of carbohydrates in the fall and does not deteriorate in quality until after January, and seems to be an ideal grass for stockpiling. Similarly, Sheehan and others (1985) described tall fescue as having significantly higher total non-structural carbohydrate (TNC) levels throughout fall and winter than orchardgrass. Bagley et al. (1983) related increasing TNC values to high voluntary intake and digestibility of tall fescue. Comparing tall fescue to bluegrass, Van Soest (1994) found that both species contained more than enough crude protein to meet the requirements of non-lactating beef cows, but tall fescue had consistently greater yields than bluegrass (Taylor and Templeton, 1976).

Orchardgrass is a perennial, tall growing, bunch-type grass. It has been shown to retain sufficient quality to sustain beef animals during late fall (Baker et al., 1988). Limited research has shown that orchardgrass stands tolerate winters in areas where the average annual temperature does not fall below $1{ }^{\circ} \mathrm{C}$ (Hannaway et al., 2004). Orchardgrass is more tolerant of shade, drought, and heat and grows more rapidly in cool weather compared to timothy (Phleum pratense L), perennial ryegrass (Lolium perenne L.), or Kentucky bluegrass (Martin and Leonard, 1967; Hall, 1994a; Myers, 1962).

Tall fescue was found to be superior to orchardgrass in yield, digestibility and for cattle weight gains in November and December (Baker et al., 1965; Archer and Decker, 1977a). Research in Virginia showed significant differences between orchardgrass and tall fescue. Cowcalf pairs were grazed on either tall fescue or orchardgrass, both grown with red clover 
(Trifolium pratense), or on orchardgrass with alfalfa (Medicago sativa). All of the grasses were fertilized in the fall with $80 \mathrm{lb}$ nitrogen $(\mathrm{N}) /$ acre. Cattle grazing tall fescue only had to be fed hay for 73 days, while those grazing orchardgrass needed hay for almost twice as long (Allen et al., 1992a). However, yields and nutritional value of stockpiled orchardgrass did not differ from tall fescue in Wisconsin (Hedtcke et al., 2002; Riesterer et al., 2000). Also, Hersom (1999) reported no difference in the amounts of supplemental hay needed to maintain gestating beef cows grazing stockpiled tall fescue-red clover or smooth bromegrass (Bromus inermis Leyss) - red clover forage.

Another cool season grass, reed canarygrass, was compared to tall fescue in an experiment conducted by Bryan et al. (1970). Both species were managed in the spring and summer and used as fall stockpiled pastures. In all periods, crude protein $(\mathrm{CP})$ was greatest for reed canarygrass, except July and early November. Both grasses were lowest in CP in June and July and highest in early October. Digestion trials reported that reed canarygrass was consumed less than tall fescue and was less digestible, except in the month of June. Differences in digestibility were significant except from September 25 to October 8 . However, when cattle were grazing, voluntary intake of the animals was higher when compared to cattle in the digestion trial. Additionally, under grazing conditions, reed canarygrass was consumed more than tall fescue. In comparing the two grass species, it was reported that first-growth tall fescue matured more quickly, resulting in lower quality than reed canarygrass on the same date. The second growth of forages differed in digestibility and voluntary intake, but both species had a comparable nutritive value. By early October, reed canary grass had a higher nutritive value than tall fescue, but by November tall fescue was higher. 
Legumes are generally not as suitable as grasses for stockpiling because their nutritive value declines rapidly as leaves are lost due to frost or maturity (Matches and Burns, 1995). In Kentucky, Collins and Taylor (1980) reported that alfalfa grown from early August was higher in yield but decreased more rapidly in quality during early fall than did alfalfa accumulated from early September. They then compared quality changes in fall-accumulated alfalfa and red clover and found that substantial declines in in-vitro dry matter digestibility (IVDMD) occurred following a combination of subfreezing temperatures and precipitation (Collins and Taylor, 1984). However, both legumes maintained CP concentrations in excess of requirements of most classes of livestock. Research conducted in Virginia by Allen et al., (1992) determined productivity and longevity of fescue grown with either alfalfa or red clover, compared to $\mathrm{N}$ fertilized fescue, managed as stockpiled forage. The use of stockpiled forages reduced the need for stored forage, but inclusion of legumes did not provide as much grazed forage as did the use of $\mathrm{N}$ fertilizer.

Among legumes, birdsfoot trefoil (Lotus corniculatus) seems to stockpile better than others (Matches and Burns, 1995) inasmuch as the nutritive value of other legumes decreases rapidly after a killing frost (Hitz and Russell, 1998). In a study conducted by Collins (1982) cutting treatments ranging from late-May to mid-October were applied to plots of birdsfoot trefoil. He observed that birdsfoot trefoil harvested during October was high in CP and IVDMD after regrowth periods of as much as 3 months. He also reported increases in TNC and decreases in neutral detergent fiber (NDF) in the October harvested-legume, relative to the summerharvested legume. The study concluded that shorter stockpiling periods resulted in higher IVDMD and lower acid detergent (ADF) and NDF fiber concentrations. However, shorter periods also resulted in lower yields. Sheehan and others (1985) studied the effects of winter on 
red clover, orchardgrass, and tall fescue in Virginia. The nutritive value of red clover tended to be as high or higher than orchardgrass and tall fescue in September and October, but then deteriorated rapidly in November, and had completely senesced by early December. More research is needed to fully understand the complexities of grass-legume mixtures for fall and winter grazing.

\section{Length of Accumulation Period}

When stockpiling forage, a compromise has to be made between yield and quality. Stockpiling should be started between mid-July and early September, depending on latitude and elevation. Low light intensity and cool temperatures end forage growth in October in New York and November in southern West Virginia (Rayburn, et al., 2007). In Virginia, Rayburn et al. (1979) reported that yield of tall fescue decreased from 3,920 to $840 \mathrm{~kg} / \mathrm{ha}$ as the stockpiling period was shortened from June to September and at the same time, TNC increased from 15.6 to $23.0 \%$ and CP increased from 9.4 to $11.3 \%$.

Collins and Balasko (1981b) showed initiation of stockpiling tall fescue in the fall provided higher quality forage when compared to summer initiation and mid- fall initiation provided higher quality forage than early-fall. Gerrish et al., (1994) stated that the length of the remaining growing season and the first freeze must be considered in determining when to initiate stockpiling. Rayburn and coworkers (1980) concluded that the best time to begin accumulating tall fescue depends on a variety of management considerations, such as the area of tall fescue, the amount of other available forages, and the nutritional needs of the livestock.

Cowling (1962) noted that if the accumulation period of alfalfa and orchardgrass is too long, alfalfa will drop its leaves and rapidly decrease in quality. Collins and Taylor (1980) in Kentucky demonstrated that DM losses of alfalfa-orchardgrass began earlier for forage 
accumulated in August than forage stockpiled in September. Also, in agreement with Cowling's findings, alfalfa accumulated from early August was lower in percent leaf, $\mathrm{N}$ and IVDMD than alfalfa accumulated from early September.

Yield of stockpiled forage is not only influenced by time of initiation, but also by grazing duration. Fribourg and Bell (1984) investigated grazing duration by analyzing yield and composition of tall fescue. They demonstrated that delaying the harvest of summer forage growth into October through December resulted in some loss of accumulated DM, but greatly increased when the harvest was delayed until January. They concluded that longer accumulation periods result in greater yields, but with lower quality.

A similar 3 year study was conducted in West Virginia by Belesky and Fedders (1995) using pastures containing orchardgrass and white clover (Trifolium repens L.) with grazing occurring from late summer into fall. Animals were removed after either 30 (early-closed), 60 or 90 (late-closed) days of grazing. When animals were removed after 30 days of grazing, herbage continued to accumulate throughout the fall which led to greater senescence of the forage over winter when compared to 60 and 90 days of grazing. Although post-grazing growth rates varied annually in the 3 year study, November yields of stockpiled forage were similar across years and averaged $3000 \mathrm{~kg} / \mathrm{ha}$ despite variations in weather. Growth rate was greatest in August and then declined thereafter. Fall forage management did not affect herbage mass in the spring. Lateclosed paddocks had significantly more clover than did early-closed paddocks in spring. Earlyclosed paddocks contained grass plants that had relatively few large tillers and white clover plants that had less growing points than those in late-closed paddocks. In comparison, late-closed paddocks had grass plants with many small tillers and white clover plants with about twice as many growing points. Concentrations of TNC were less during autumn in late- than in early- 
closed paddocks, but stolon mass was greater. The decrease in clover mass over the course of the experiment corresponded with a decrease in total herbage mass. The authors concluded that a delicate balance between growing points and carbohydrates may be involved in clover presence in mixed swards.

\section{Animal Performance}

In Virginia, McClure et al., (1977) fed light steer calves on stockpiled fescue for $112 \mathrm{~d}$ starting January 8, with or without supplemental corn at $1 \%$ body weight (BW). Unsupplemented calves gained $0.51 \mathrm{~kg} / \mathrm{d}$ and supplemented calves gained $0.66 \mathrm{~kg} / \mathrm{d}$. In another study under similar conditions (Gerken and McClure, 1979), calves were grazed from Jan 4 through April 26 on stockpiled fescue with no supplement or with $2 \mathrm{lb}$ of a $12 \% \mathrm{CP}$ concentrate with or without $200 \mathrm{mg}$ monensin. Calves gained $0.30,0.53$ and $0.59 \mathrm{~kg} / \mathrm{d}$ on the respective treatments.

In a study comparing stocker systems in Virginia (Allen et al., 1992), calves were grazed on stockpiled fescue as opposed to other forage systems including stockpiled fescue/alfalfa and orchardgrass/alfalfa hay for 151 days starting November 1 . When calves had utilized all the stockpiled forages, they were fed hay produced earlier on the same pastures. Calves on stockpiled fescue required fewer days of supplemental hay than the other treatments, but gained less $(0.34 \mathrm{~kg} / \mathrm{d})$ than calves that grazed either fescue/alfalfa or that were wintered on orchardgrass/alfalfa hay $(0.50 \mathrm{~kg} / \mathrm{d})$.

Hitz and Russell (1998) compared the nutritive value of differing perennial forage species and corn crop residues that were stockpiled for winter grazing management and quantified the required amount of stored forage that was required to maintain pregnant beef cows. Mid-gestation cows were allotted strip-grazing treatments with various perennial stockpiled forage species or corn crop residues. The cows that wintered on stockpiled tall fescuealfalfa had the highest mean BW and body condition change of all wintering systems and 
stockpiled forages as a whole showed better cow performances when compared to corn crop residues. Cows wintered on stockpiled pastures of tall fescue-alfalfa and smooth bromegrass also required less supplemented hay than cows on corn crop residues. Hedtcke and others (2002) conducted a study to determine the quality changes of seven stockpiled cool-season grasses early and late maturing orchardgrass, quackgrass (Elytrigia repens L.), reed canarygrass, smooth bromegrass, tall fescue, and timothy. They concluded that any of the seven stockpiled grasses had adequate quality for animal classes with low nutrient requirements such as dry beef cows and sheep. However, animals with higher nutrient requirements will require protein and energy supplementation beyond December.

A study conducted by Meyer et al., (2009) demonstrated that stockpiling tall fescue is a viable option for wintering spring-calving beef cows. The treatments in the study consisted of tall fescue hay (HY), hay supplemented to meet NRC requirements (HS), or strip-grazed stockpiled tall fescue pasture (STF). Differences between the nutritive value of tall fescue-based grass hay fed in this study and stockpiled tall fescue made it necessary to supplement cows fed hay to achieve performance similar to that observed when grazing stockpiled tall fescue. Additionally, during the winter feeding period of yr 2, three calves born in the HY treatment and four born in the HS treatment died resulting from hypothermia or respiratory illness, whereas no calves born in the STF paddocks died. Although mortality rate was not statistically significant ( $P$ $=0.22$ ), it was observed that strip-grazing STF provided fewer areas where mud could form during the wet conditions of yr 2, because cattle constantly moved to graze in a new area, thereby reducing the time calves spent in wet areas.

Due to the high cost of $\mathrm{N}$ fertilizer and the potential for groundwater pollution, there is renewed interest in the use of grass-legume combinations for pasture and hay production. Burns 
and co-workers (1973) reported higher gains per calf on tall fescue-ladino clover compared to calves grazing tall fescue alone or fescue plus 'Coastal' bermudagrass (Cynodon dactylon). Steer daily gains, overall gains and feed efficiency were highest on orchardgrass-clover pastures compared to steers grazing bermudagrass-clover, fescue-clover and bermudagrass $+\mathrm{N}$ or bermudagrass $+\mathrm{N}+$ fescue pasture (McLaren et al., 1983). On the other hand, more beef was produced per hectare on bermudagrass + fescue due to greater forage production and a longer grazing season.

\section{INDUCTION OF PUBERTY}

\section{Hormonal Regulation}

The onset of puberty is the result of a series of complex developmental events that occur within the reproductive endocrine axis (Ahmadzadeh et al., 2011). The fundamental requirement for the initiation of puberty is the secretion of a gonadotropin releasing hormone $(\mathrm{GnRH})$ from the hypothalamus at the appropriate frequency and quantities to stimulate luteinizing hormone (LH) release from the anterior pituitary (Senger, 1999; Day et al., 1998). A key factor in increasing circulating $\mathrm{LH}$, follicular development, and therefore synthesis and secretion of estradiol $17 \beta$ (E2) is an increase in pulse frequency of GnRH. In 1999, Senger demonstrated that the frequency of the GnRH pulses in prepubertal heifers is much lower than the frequency of GnRH pulses in the postpubertal heifers.

In the prepubertal heifer, the frequency of GnRH release and subsequently LH remain low due to the sensitivity of the hypothalamic tonic center to the negative feedback effect generated by E2. As the onset of puberty approaches, the hypothalamic tonic center's sensitivity to E2 decreases resulting in an increase in the release of GnRH from the hypothalamus and gonadotropins from the anterior pituitary (Day et al., 1984, 1998). This leads to follicular growth and development, and hence the synthesis and secretion of greater amounts of E2. At onset of puberty, a shift from negative 
feedback to positive feedback in the hypothalamic surge center, due to elevated concentrations of ovarian E2, results in a surge of GnRH, which triggers a surge of LH (Senger, 1999). The surge of LH prompts the expression of behavioral estrus (heat) and ovulation. A representation of the endocrine and ovarian changes associated with the onset of puberty in the heifer and factors affecting interval to puberty onset are presented in Figure 1 below.

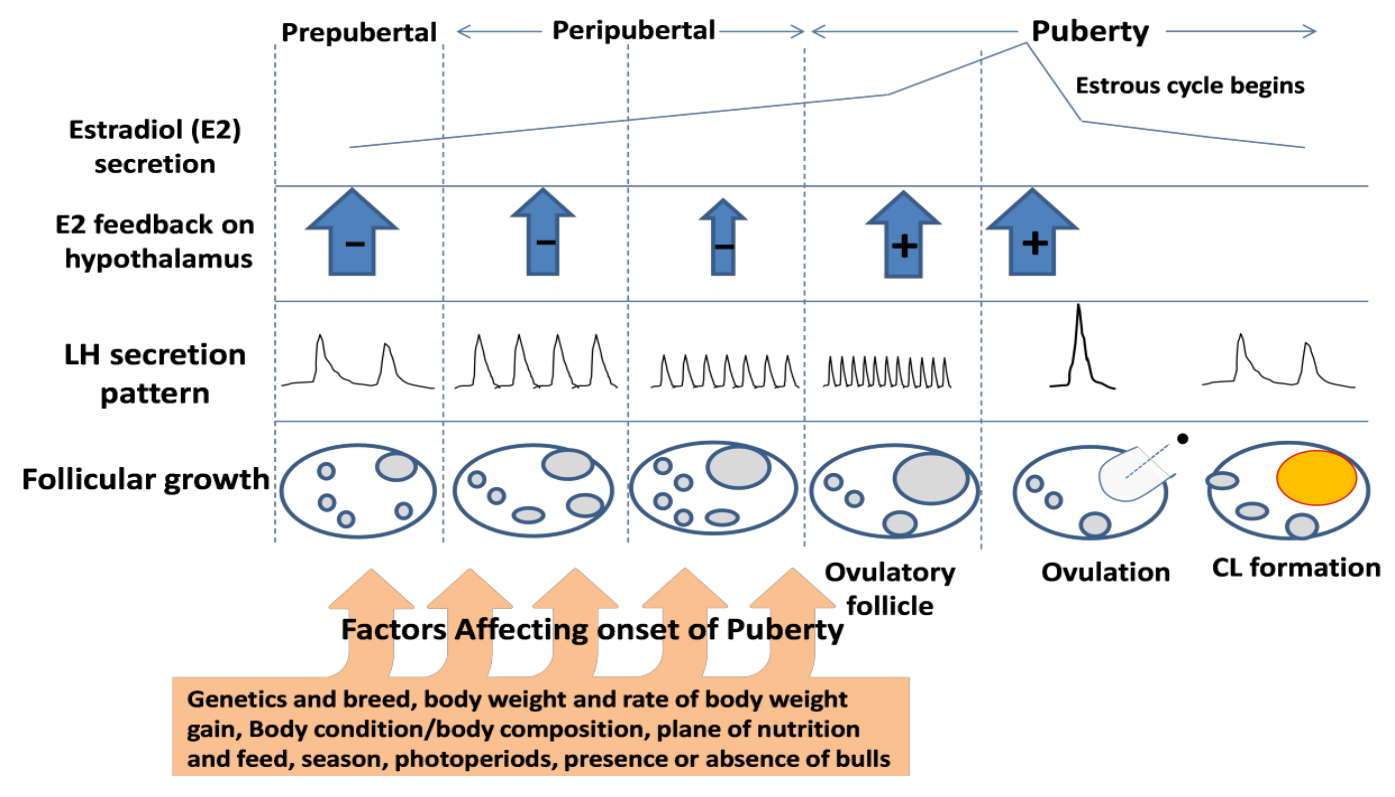

Figure 1. Endocrine and ovarian changes associated with puberty onset in the heifer and factors affecting interval to puberty onset. (Ahmadzadeh, A., K. Carnahan, and C. Autran. 2011. Understanding Puberty and Postpartum Anestrus. In Proceedings, Applied Reproductive Strategies in Beef Cattle. Boise, ID. - adapted and modified from Williams and Amstalden, 2010) $\mathrm{E} 2$ = estradiol; $\mathrm{LH}=$ luteinizing hormone; $\mathrm{CL}=$ corpus luteum

Although the rate-limiting factor for the onset of puberty is the secretion of high amplitude, high frequency GnRH pulses, and ovarian E2 feedback system with the hypothalamus; there are also complex sets of neural pathways, neurohormones, and peptides that modulate GnRH secretion itself and mediate the effect of E2 on GnRH. Recent research involving neuropeptide Y and, agoutirelated peptides (Allen et al., 2009), dopamine (Ahmadzadeh et al., 2011), opioid peptides (Cosgrove et al., 1993), and kisspeptin and its receptors (Kadokawa et al., 2008), have all shown to play 
essential roles in the secretion of $\mathrm{GnRH}$ and $\mathrm{LH}$, and also in facilitating steroid feedback communication to the hypothalamus. Furthermore, research by Whittier et al., 2008, has demonstrated that as the heifer ages, these factors interact with various internal metabolic signals, such as glucose, propionate, leptin, ghrelin, insulin-like growth factor-1, and its transport proteins that are recognized by receptors in the central nervous system.

Progestins have been shown to induce puberty in prepubertal heifers (Gonzalez-Padilla et al., 1975a,b; Berardinelli, 1976; Patterson et al., 1990; Short et al., 1976) and are often combined with estrogen to mimic changes that occur in blood hormone concentrations during the time of puberty (Patterson et al., 1992). Progestins stimulate an increase in follicular growth that results in increased estrogen production by ovarian follicles (Garcia-Winder et al., 1986). Patterson et al. (1990) fed $.5 \mathrm{mg}$ of melengestrol acetate (MGA) per animal per day for $7 \mathrm{~d}$ to 60 prepubertal heifers and observed $67 \%$ of the heifers exhibiting estrus within $6 \mathrm{~d}$ after MGA withdrawal.

\section{FACTORS AFFECTING ONSET OF PUBERTY}

A variety of factors affect onset of puberty including body weight, genetics, nutritional status, photoperiod, and season of birth. A brief discussion of these factors that affect age at puberty follows.

\section{Body Weight}

Studies in several species provide evidence that diet during development partially controls physiological changes necessary for puberty (Frisch, 1984). Numerous studies have reported inverse correlations between post-weaning growth rate and age at puberty (Arije and Wiltbank, 1971; Ferrell, 1982; Short and Bellows, 1971; Wiltbank et al., 1966, 1969, 1985). Traditional recommendations advocate substantial energy inputs for replacement heifer development because pregnancy rates in heifers depend on the number of heifers displaying 
estrus early in the breeding season (Short and Bellows, 1971). Thus, rate of post-weaning growth was determined to be an important factor affecting age of puberty, which influenced pregnancy rates.

Early research indicated that puberty can be expected to occur at a genetically predetermined size and only when heifers reach genetically predetermined target weights can high pregnancy rates be obtained (reviewed by Patterson et al., 1992). The target weight principle states that heifers should reach a pre-breeding target weight of 60 to $65 \%$ of their expected mature body weight (Patterson et al, 1992). Research reports published through the late 1980s have shown greater negative effects of restricted post-weaning growth on age of puberty and subsequent pregnancy (Patterson et al., 1989; Short and Bellow, 1971; Wiltbank et al., 1985), whereas more recent studies indicate less of a negative effect of delayed puberty on pregnancy response (Buskirk et al., 1995; Freetly et al., 1997; Lynch et al., 1997).

Since inception of target weight guidelines, recent research has demonstrated that input of harvested feed can be reduced without major adverse effects on reproductive performance by altering pattern of body weight gain (Freetly et al., 2001) or by feeding to lighter target body weights than those typically recommended (Funston and Deutscher, 2004) thereby reducing the cost of raising heifers. Altering rate and timing of gain can result in periods of compensatory growth and/or allow producers to limit supplementation to critical periods of heifer development thereby providing an opportunity to decrease feed costs (Clanton et al., 1983; Freetly et al., 2001; Lynch et al., 1997). In a study conducted by Lynch et al. (1997), heifer gain was delayed until 47 or $56 \mathrm{~d}$ prior to the breeding season and this did not negatively influence first service conception rates or overall pregnancy rates, but reduced the amount of feed needed. This study also demonstrated that puberty was delayed in heifers fed to achieve lower early gains, but first- 
service conception rate tended to be improved in these same heifers. Similar results were found in another study performed by Freetly (2001). In this study, gain was delayed until the later part of the post-weaning period. Total energy intake was reduced, but calving rate, age at calving, postpartum interval, and second year pregnancy rate were not impacted. These studies suggest limiting heifer gain early in the post-weaning period followed by accelerated gains before breeding may reduce heifer development costs without negatively impacting heifer reproductive performance.

Ciccioli et al. (2005) compared heifers grazing pasture supplemented with $0.9 \mathrm{~kg} / \mathrm{d} 42 \%$ CP pellet over the winter to heifers in a dry-lot fed high-starch diets for 30 or $60 \mathrm{~d}$ and heifers self-fed low starch diets on pasture. Pregnancy rates were similar among groups, however pasture-developed heifers were older at puberty. The same study compared heifers developed on pasture and supplemented with energy for $60 \mathrm{~d}$ prior to breeding to heifers receiving only 0.9 $\mathrm{kg} / \mathrm{d} 42 \% \mathrm{CP}$ pellets. Supplementation improved pregnancy rates when pubertal development was limited by winter ADG, but if heifers achieved moderate $(0.51 \mathrm{~kg} / \mathrm{d})$ winter gains, pregnancy rates were not improved by supplementation.

Feeding to pre-breeding body weight (BW) as light as $51 \%$ of mature body weight was shown to be more cost effective than development to 57\% of mature BW (Martin et al., 2008). Funston and Larson (2011) compared traditional post-weaning dry lot (DL) development with a more extensive winter grazing system utilizing a combination of corn residue and winter range (EXT). By breeding, EXT heifers reached $56 \%$ of mature BW compared to DL heifers, which attained $65 \%$ of mature BW $(P=0.02)$. Grazing heifers on corn residue or winter grass for a portion of post-weaning development did not affect AI conception rate compared with heifers developed in a DL $(P=0.23)$. However, AI pregnancy rate tended to be less $(P=0.08)$ for EXT 
heifers. However, final pregnancy rate was not different $(P=0.38)$ between EXT and DL heifers. Heifer development using extended winter grazing reduced $(P<0.01)$ the cost of producing a pregnant heifer by $\$ 45$ compared with DL. Funston and Deutscher (2004) reported a $\$ 22 /$ heifer savings from developing heifers to $53 \%$ of mature BW by breeding compared with heifers reaching $58 \%$ of mature BW. Similarly, developing heifers in a DL to $50 \%$ of mature BW reduced the cost by $\$ 24$ per pregnant heifer compared with development to 55\% (Martin et al., 2008). Feuz (2001) determined that reducing percentage of mature BW from 65 to $55 \%$ reduced the net cost of developing a pregnant heifer by $\$ 19 /$ heifer. This reduction in cost was noted in spite of a $9 \%$ reduction in pregnancy rate.

Due to rising costs of inputs, interest in alternative heifer development systems minimizing the use of harvested feedstuffs in favor of grazing is increasing. However, dormant forages are lower in available nutrients and may result in poorer animal performance, leading to lower body weights at breeding. Recent data, however, indicates heifers reaching less than $58 \%$ of mature body weight by breeding have similar reproductive ability as their heavier counterparts (Funston and Deutscher, 2004; Martin et al., 2008). In the Funston and Larson (2011) study, winter grazing was found to be a suitable alternative to a dry lot for heifer development. This study and others indicate developing heifers to less than $65 \%$ of mature BW by breeding is economically superior to a greater BW development. Consequently, employing heifer development systems that utilize grazing standing forage may not only be cost effective but also effective in terms of reproductive performance.

\section{Genetics}

Numerous studies have reported both between-breed and within-breed differences in age and weight at puberty as well as subsequent reproduction in beef cattle. Breed differences, sire 
and dam effects within a breed, and heterosis contribute to genetic control of age at puberty. Reynolds et al. (1963), and many others, found that various breeds and breed crosses of cattle differ in weight and age attained at the onset of puberty. Reynolds et al. (1963) reported that ages at first estrus for Angus, Brahman, and reciprocal cross heifers were 433, 816 and 460 days, respectively. Earlier work by Warnick et al. (1956) showed that age at puberty in Brahman heifers was older than that of British breeds. Plasse et al. (1968) found that Brahman heifers attained puberty at 19.4 months with a range of from 14 to 24 months. Wiltbank et al. (1966) illustrated a significant effect of heterosis on weight and age at puberty in reciprocal crosses of Angus, Hereford, and Shorthorn heifers. Ferrell (1982) reported a significant reduction of age at puberty in crossbred heifers when compared to straight bred heifers.

\section{Photoperiod and Season of Birth}

Cattle are not seasonal breeders, however, several experiments have described seasonal variations in bovine reproductive activity. Plasse et al., (1968) showed that the reproductive activity of Brahman heifers, as measured by frequency of corpora lutea and uterine tone, increased during the spring, peaked during the summer, and decreased to a minimum during the winter. Studies by Hawk et al., (1954) and Menge et al., (1960), documented an effect of season of birth on age at puberty in dairy heifers. From their experiments, they concluded that heifers born during the spring and summer were younger at first estrus than were heifers born at other times of the year. In agreement with these findings, Arije and Wiltbank (1971), reported that spring-born beef heifers reached puberty at an earlier age than heifers born during other seasons.

There are, however, discrepancies among experiments concerning effects of season on onset of puberty in cattle. An experiment conducted by Schillo and others (1982), demonstrated that Angus $\mathrm{x}$ Holstein heifers born in autumn attained puberty at younger ages than heifers born in spring. Additionally, Tortonese and Inskeep (1992), showed that spring-born heifers treated with 
exogenous melatonin to simulate short day length early in life reached puberty earlier than untreated control heifers. Nevertheless, the effects of season on attainment of puberty in cattle are evident and other less-defined factors such as ambient temperature also affect the onset of puberty (Schillo et al., 1992).

\section{COMPENSATORY GROWTH}

\section{Introduction}

Hornick et al. (2000) defined compensatory growth as a "physiological process whereby an organism accelerates its growth curve after a period of restricted development, usually due to reduced feed intake, in order to reach the weight of animals whose growth was never reduced." The first report on the subject was in 1908 by Waters (1908), who noted that beef steers that had been undernourished subsequently recovered to reach normal mature weight and height. The term "compensatory growth" was first used by Bohman (1955) to describe the effects of diet on the growth of beef cattle. These and other studies have shown that the animals' ability to compensate for prior nutrient restriction is affected by severity and duration of the period of restriction, stage of development of the animal (effects on cellular proliferation relative to differentiation of each tissue), genotype, sex, level of feed intake during realimentation, period of refeeding, and composition of the diet during realimentation (Mitchell, 2007).

\section{Nutrient Restriction}

Growth is an increase in mass of tissues or organs by hyperplasia and /or hypertrophy (Owens et al., 1993). During normal development, muscle initially exhibits the highest growth rate followed by fat tissue and when growth rates are reduced, there is an associated decrease of tissue turnover (Hornick,et al., 2000). However, some tissues are affected more than others. Because fat deposition is more affected than protein deposition the body becomes leaner and if 
fed at maintenance levels, muscle growth is close to zero, but fat mobilization continues and visceral weight decreases markedly (Yambayamba et al, 1996). Severe feed restriction and weight loss are characterized by a sharp decrease in body tissue synthesis relative to degradation which indicates that the mechanisms of synthesis are much more sensitive to low (and high) feeding intensity than degradation (Hayden et al., 1993). With severe restriction, very labile protein stores are mobilized first, followed by metabolism of fat and then muscle (Hornick et al., 2000). However, when lean animals are feed-restricted, muscle constitutes the main source of energy, causing greater protein than fat losses (Foot and Tulloh, 1977).

Tissues with high metabolic activity, such as the liver and intestines, undergo rather large decreases in mass. On the other hand, effects on early maturing tissue such as bone are generally negligible (Carstens et al., 1991; Kamalzadeh et al., 1998a). Drouillard et al. (1991) investigated the changes in body composition and visceral organ size during restricted and compensatory growth following restrictions of metabolizable protein (MP) or net energy (NE) in lambs. In response to MP and NE restrictions, weights of liver, stomach complex, and intestines were less in lambs. During the compensatory growth period, liver and stomach complex weights increased and intestinal weights increased for the first 14 days and then plateaued. Restricted lambs, regardless of type of restriction, had almost a $40 \%$ decrease in oxygen uptake by liver tissue, indicating that previously restricted animals have lower maintenance energy requirements. The maintenance energy level of these animals will remain low even into the early stages of the compensatory period because less energy is needed to maintain the animal's body and more energy can be utilized for gain.

Animals on restricted nutrient intakes develop reduced resting metabolic rates (Yambayamba et al., 1996). During the feed restriction period, resting metabolic rate is reduced 
and accompanied by shifts in nutrient metabolism and energy stores (Drouillard et al., 1991b). Basal metabolism is reduced due to a decrease of the volume and the metabolic activity of the viscera (Ortigues and Durand, 1995; Paquay et. al., 1972). Plasma concentrations of glucose, total protein and urea nitrogen decrease and plasma creatinine and non-esterified fatty acids (NEFA) levels increase during feed restriction (Hayden et al., 1993; Yambayamba et al., 1996; Hornick et al., 1998b; Sahlu et al., 1999). These changes are brought about by altered endocrine conditions. During feed restriction, plasma insulin, triiodothyronine (T3), thyroxine (T4), and IGF-1 concentrations decrease while cortisol and somatropin (GH) levels increase (Hayden et al., 1993; Barash et al., 1998; Hornick et al., 2000).

The low concentration of thyroid hormones is in part the result of decreased responsiveness of the thyroid to thyroid-stimulating hormone (Wester et al., 1995). Lower concentrations of $\mathrm{T} 3$ and $\mathrm{T} 4$ allow the organism to spare energy by decreasing basal metabolism (Hornick et al., 2000). The increase in plasma GH concentrations results from two processes. First, a reduction in nutrient intake decreases the release of somatostatin by the hypothalamus and thus lessens the negative effect on the synthesis and release of GH (Thomas, et al., 1990). Secondly, as a consequence of decreased plasma levels of hormones such as insulin, T3 and T4, the synthesis of GH receptors and plasma levels of GH binding proteins are decreased (Maes et al., 1983). Nutrient restriction has been shown to affect reproductive performance. Kamalzadeh et al. (1998a, b) reported a decrease in the size of testes due to feed restriction. Also, it has been demonstrated that nutrient restriction can adversely affect the ovarian cycle, conception, fecundity, and twinning rate (Roberts et al., 1997; Cassady et al., 2009; Kusina et al., 2001). 


\section{Realimentation Period}

During the realimentation period when nutrient intake is unrestricted or at a higher level, the decrease in energy expenditure during the period of feed restriction continues with a higher plane of nutrition (Drouillard et al., 1991b; Yambayamba et al., 1996). The length of this effect is dictated by the severity and length of the restriction (Drouillard et al, 1991b). Carstens et al. (1991) found lower energy concentrations in tissue being accreted after restriction as well as a possible increase in gut digesta mass. His study compared two treatments, a continuous feeding regime $(\mathrm{CON})$ and a restricted/compensatory growth $(\mathrm{CG})$ feeding regime where steers were restricted to grow at $0.45 \mathrm{~kg} / \mathrm{d}$. At 189 days growth restriction, $\mathrm{CG}$ steers were realimented to ad libitum intake. A serial slaughter technique was used and steers were slaughtered at approximately $325 \mathrm{~kg} \mathrm{BW}, 420 \mathrm{~kg} \mathrm{BW}, 475 \mathrm{~kg} \mathrm{BW}$, and $500 \mathrm{~kg} \mathrm{BW}$. During the first 45 days of realimentation the liver mass of the CG steers increased by $40 \%$. It was also observed that noncarcass protein and water accretion was greater for the CG steers than CON steers and lipid accretion was reduced in non-carcass and carcass tissues in CG steers during realimentation. It was estimated that for 2 to 3 months after the restriction is removed, there is a decreased net energy for gain requirement for growth of cattle during a compensatory period and net energy use for gain is more efficient (18\% more efficient in this study). It was concluded that reduced NEg requirements and changes in gut fill accounted for most of the compensatory growth response in the steers.

As during the period of nutrient restriction, during realimentation shifts in nutrient metabolism and endocrine conditions occur. It has been demonstrated that during the compensatory period plasma glucose and urea nitrogen increases and plasma NEFA and creatinine levels decrease (Hayden et al., 1993; Hornick et al., 1998b). During nutrient repletion, 
serum IGF-1 increased and was positively correlated with empty body protein accretion in compensating steers (Wester et al., 1995). Effects of feed restriction during realimentation on GH, T3 and T4 levels are not consistent. Hornick et al., (1998b) reported decreasing levels of GH while Yambayamba et al., (1996) reported elevated levels of GH in beef heifers until day 104 of realimentation. Hayden et al., (1993) showed no response of T4 to repletion and an increase in T3, whereas Hornick et al, (1998b) showed an increase in T4 and an inconsistent change in $\mathrm{T} 3$.

\section{Factors Affecting Compensatory Growth}

As previously stated, compensatory gain depends on factors such as age at which restriction began, length and severity of the restriction, nature of realimentation diet, length of time realimentation diet is fed, and breed type (Mitchell, 2007). Thorton et al., (1979) reported that young animals are more sensitive to restriction than older animals. In young animals, restricted nutrient intake can hinder cell division and reduce the degree of compensation (Thorton et al., 1979; Tudor et al., 1980). Level of maturity also influences subsequent body composition variations. More mature animals tend to deposit tissue higher in protein during compensation, while younger animals tend to deposit tissue higher in fat (Tudor et al., 1980).

Kamalzadeh et al., (1998a, b) varied the length of nutrient restriction by withholding a $17 \%$ CP concentrate supplement for 3 or 4.5 months. Rate of weight loss was not affected, but the time of realimentation necessary for animals to reach the same weight as unrestricted animals was increased. Drouillard et al., (1991a) reported that the length of time of nutrient restriction influences the degree of compensatory growth, with energy intake restriction having a greater impact than protein intake. He conducted a study evaluating the effects of NE and MP restriction during the growing phase on compensatory growth. For both NE and MP restricted 
animals, ADG was similar during restriction; however, NE restricted animals experience greater compensatory growth than MP restricted animals. This may be due to an immediate impact of protein restriction on hormonal conditions, but not on visceral mass or metabolic activity compared with energy restriction (Wester et al., 1995).

On the other hand, Abdalla et al. (1988) demonstrated that regardless of whether an animal's diet is energy or protein restricted, realimentation to a higher plane of nutrition will result in compensatory gain. Holstein steers were fed three different diets that were protein deficient (L), protein sufficient $(\mathrm{H})$, or energy restricted (ER) during the first period. In the second period, half the calves in each group were fed $\mathrm{H}$ and half were fed L. At the end of the second period, a high energy diet was fed to all calves until they were estimated to be $26 \%$ body fat. Compensating calves consumed more feed per unit metabolic BW. Efficiency of gain was higher for the compensating groups. The restricted groups required more days to reach a similar percentage final body weight. Realimented steers gained faster than the controls and had better efficiencies of feed utilization regardless of when they were restricted or realimented or whether restriction was caused by underfeeding energy or protein. It was concluded that compensatory growth involves both an increase in relative DMI and an increase in efficiency of use of ME. Klopfenstein and others (1999) compiled data from several compensatory gain studies conducted by the University of Nebraska over many years. From these studies, it was observed that the range in compensation with cattle grazing season-long is $19-88 \%$ with a mean of $53 \%$ and that days of restriction appeared to be the only variable related to percentage compensation. They also concluded that most of the compensation on grass can be explained by intake of NEg above maintenance and that longer restriction and partial season grazing reduces compensatory gain. 


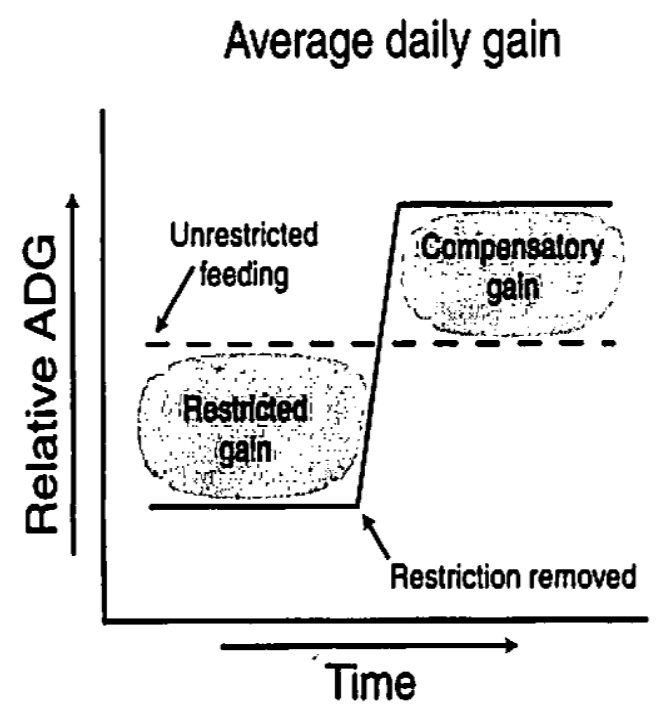

Cumulative body weight

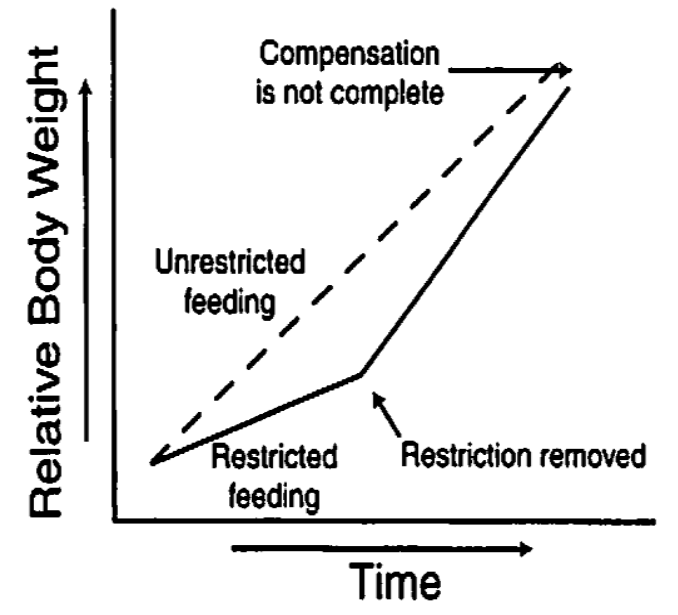

Figure 2. Schematic representation of compensatory gain in relation to ADG and animal BW. (Allen, V.G. and M. Collins. 2003. Forages: An introduction to Grassland Agriculture, Volume 1. Iowa State Press, Ames.) 


\section{REFERENCES}

Abdalla, H. O., D. G. Fox, and M. L. Thonney. 1988. Compensatory gain by Holstein calves after under-feeding protein. J. Anim. Sci. 66:2687-2695.

Ahmadzadeh, A., K. Carnahan, and C. Autran. 2011. Understanding Puberty and Postpartum Anestrus. In Proceedings, Applied Reproductive Strategies in Beef Cattle. Boise, ID.

Allen, V.G. and M. Collins. 2003. Forages: An introduction to Grassland Agriculture, Volume 1. Iowa State Press, Ames.

Allen, V.G., J.P. Fontenot, D.R. Notter, and R.C. Hammes, Jr. 1992a. Forage systems for beef production from conception to slaughter: I. Cow-calf production. J. Anim. Sci. 70:576-587.

Allen, V.G., J.P. Fontenot, and D.R. Notter. 1992. Forage systems for beef production from conception to slaughter II. Stocker systems. J. Anim. Sci. 70: 588- 596.

Allen, C. C., X. Li, L. O. Tedeschi, H. Zhou, J. A. Paschal, T. E. Spencer, U. M. Braga- Neto, D.H. Keisler, M. Amstalden, and G. L.Williams. 2009. Dietary treatments that facilitate early onset of puberty in heifers alter gene expression in the arcuate nucleus. Proc. Soc. Study Reprod. (Abstract 489).

Arije, G.F., and J.N. Wiltbank. 1971. Age and weight at puberty in Hereford heifers. J. Anim. Sci. 33:401-406.

Archer, K.A., and A.M. Decker. 1977a. Autumn-accumulated tall fescue and orchardgrass. I. Growth and quality as influenced by nitrogen and soil temperature. Agron. J. 69:601605.

Bagley, C.P., J.P. Fontenot, R.E. Blaser, and K.E. Webb Jr. 1983. Nutritional value and voluntary intake of tall fescue (Festuca arundinacea Schreb.) fed to sheep. J. Anim. Sci. 57: 1383-1390.

Baker, H.K., J.R.A. Chard, and W.E. Hughes. 1965. A comparison of cocksfoot- and tall fescue-dominant swards for out-of-season production. J. Br. Grassl. Soc. 20:84-90.

Baker, M.J., E.C. Prigge, and W.B. Bryan. 1988. Herbage production from hay fields grazed by cattle in fall and spring. J of Production Agriculture. 1: 275- 279.

Barash H., Y. Aharoni, A. Brosh, and Z. Holzer. 1998. Effects of low energy diets followed by a compensatory diet on body weight gain and plasma hormone concentrations in bull calves. J. Dairy Sci. 81:250-254.

Barnes, R.F., C.J. Nelson, M. Collins, and K.J. Moore. 2003. Forages: An Introduction to Grassland Agriculture, Volume 1. Iowa State Press, Ames. 
Beleskey, D.P. and J.M. Fedders. 1995. Influence of autumn management on orchardgrasswhite clover swards. Agron. J. 87:1186-1192.

Berardinelli, J.G. 1976. Induction of puberty in beef heifers. M.S. Thesis, West Virginia University, Morgantown.

Bohman VR. 1955. Compensatory growth of beef cattle. The effect of hay maturity. J Anim Sci.;14:249-55.

Bouton, J. H., and A. A. Hopkins. 2003. Commercial applications of endophytic fungi. p. 495 in Clavicipitalian Fungi, Evolutionary Biology, Chemistry, Biocontrol, and Cultural Impacts. Academic Press, New York, NY.

Burns, J.C., L. Goode, H.D. Gross, and A.C. Linnerud. 1973. Cow and calf gains on ladino clover-tall fescue and tall fescue grazed alone and with coastal bermudagrass. Agron. J. 65:877-880.

Bryan, W.B., W.F. Wedin, and R.L. Vetter. 1970. Evaluation of reed canarygrass and tall fescue as spring-summer and fall-saved pasture Agron. J. 62:75-80.

Buskirk, D.D., D.B. Faulkner, and F.A. Ireland. 1995. Increased postweaning gain of beef heifers enhances fertility and milk production. J. Anim. Sci. 73:937-946.

Byerley, D.J., R.B. Staigmiller, J.G. Berardinelli, and R.E. Short. 1987. Pregnancy rates of beef heifers bred either on pubertal or third estrus. J. Anim. Sci. 65:645-650.

Carstens, G. E., D. E. Johnson, M. A. Ellenberger, and J. D. Tatum. 1991. Physical and chemical components of the empty body during compensatory growth in beef steers. J. Anim. Sci. 69:3251-3264.

Cassady, J.M., T.D. Maddock, A. DiCostanzo, and G. G. Lamb. 2009. Initial body condition score affects hormone and metabolite response to nutritional restriction and repletion in yearling postpubertal beef heifers. J. Anim. Sci. 87:2262-2273.

Ciccioli, N.H., S.L. Charles-Edwards, C. Floyd, R.P. Wettemann, H.T. Purvis, K.S. Lusby, G.W. Horn, and D.L. Lalman. 2005. Incidence of puberty in beef heifers fed high- or lowstarch diets for different periods before breeding. J. Anim. Sci. 83:2653-2662.

Clanton, D.C., L.E. Jones, and M.E. England. 1983. Effect of rate and time of gain after weaning on the development of replacement beef heifers. J. Anim. Sci. 56:280-285.

Clark, R. T., K. W. Creighton, H. H. Patterson, and T. N. Barrett. 2005. Symposium paper: Economic and tax implications for managing beef replacement heifers. Prof. Anim. Sci. 21:164-173. 
Collins, M. 1982. Yield and quality of birdsfoot trefoil stockpiled for summer utilization. Agron. J. 74:1036-1041.

Collins, M., and J.A. Balasko. 1981b. Effects of $\mathrm{N}$ fertilization and cutting schedules on stockpiled tall fescue. II. Forage quality. Agron. J. 73:821-826.

Collins, M., and T.H. Taylor. 1980. Yield and quality of alfalfa harvested during autumn and winter and harvest effects on the spring crop. Agron. J. 72:839-844.

Collins, M., and T.H. Taylor. 1984. Quality changes of late summer and autumn produced alfalfa and red clover. Agron. J. 76:409-415.

Cosgrove, J.R, F. de Rensisand, and G.R. Foxcroft. 1993. Opioidergic pathways in animal reproduction: Their role and effects of their pharmacological control. Anim. Reprod. Sci. 33:373-392.

Cowling, D.W. 1962. The production of winter grass from a row crop of cocksfoot and alfalfa. J. Br. Grassl. Soc. 17:161-166.

Day M. L., K. Imakawa, M. Garcia-Winder, D. D. Zalesky, B. D. Schanbacher, R. J. Kittok, and J. E. Kinder. 1984. Endocrine mechanisms of puberty in heifers: estradiol negative feedback regulation of luteinizing hormone secretion. Biol. Reprod. 31:332-341.

Day, M. L., and L. H. Anderson. 1998. Current concepts on the control of puberty in cattle. J. Anim. Sci. 76(Suppl. 3):1-15.

Davies, W., and T.W. Fagan. 1938. Winter keep on temporary leys. Emp. J. Exp. Agric. 6:369-376.

Drouillard, J. S., C. L. Ferrell, T. J. Klopfenstein, and R. A. Britton. 1991a. Compensatory growth following metabolizable protein or energy restrictions in beef steers. J. Anim. Sci. 69:811-818.

Drouillard, J. S., T. J. Klopfenstein, R. A. Britton, M. L. Bauer, S. M. Gramlich, T. J Wester, and C. L. Ferrell. 1991b. Growth, body composition, and visceral organ mass and metabolism in lambs during and after metabolizable protein or net energy restrictions. J. Anim. Sci. 69:3357-3375.

D’Souza, G.E., E.W. Maxwell, W.B. Bryan, and E.C. Prigge. 1990. Economic impacts of extended grazing systems. American Journal of Alternative Agriculture. 5:120-125.

Fales, S. L. 1986. Effects of temperature on fiber concentrations, composition, and in vitro digestion kinetics of tall fescue. Agronomy Journal 78:963-966.

Ferrell, C.L. 1982. Effects of postweaning rate of gain on onset of puberty and productive performance of heifers of different breeds. J. Anim. Sci. 55:1272. 
Ferrell, C. L., and T. G. Jenkins. 1985. Cow type and the nutritional environment: Nutritional aspects. J. Anim. Sci. 61:725-741.

Feuz, D. M. 2001. Economics of young female management. Proc. Range Beef Cow Symp., Casper, WY. Univ. Wyoming, Laramie.

Foot J.Z., and N.M. Tulloh. Effects of two paths of live-weight change on the efficiency of feed use and on body composition of Angus steers. J Agric Sci (Camb) 1977;88:135- 42.

Freetly, H.C., and L.V. Cundiff. 1997. Postweaning growth and reproduction characteristics of heifers sired by bulls of seven breeds and raised on different levels of nutrition. J. Anim. Sci. 75:2841-2851.

Freetly, H.C., C.L. Ferrell, and T.G. Jenkins. 2001. Production performance of beef cows raised on three different nutritionally controlled heifer development programs. J. Anim. Sci. 79:819-826.

Fribourg, H.A., and K.W. Bell. 1984. Yield and composition of tall fescue stockpiled for different periods. Agron. J. 76:929-934.

Frisch, R.E. 1984. Body fat, puberty and fertility. Biol. Rev. 59:161-188.

Funston, R.N., and G.H. Deutscher. 2004. Comparison of target breeding weight and breeding date for replacement beef heifers and effects on subsequent reproduction and calf performance. J. Anim. Sci. 82:3094-3099.

Funston, R., Martin, J., Roberts, A. 2009. Extensive Heifer Development Systems Proceedings, The Range Beef Cow Symposium XXI Casper, WY.

Funston, R. N. and D.M. Larson. 2011. Heifer development systems: Dry-lot feeding compared with grazing dormant winter forage. J. Anim. Sci. 89:1595-1602.

Garcia-Winder, M., P. E. Lewis, D. R. Deaver, V. G. Smith, G. S. Lewis, and E. K. Inskeep. 1986. Endocrine profiles associated with the life span of induced corpora lutea in postpartum beef cows. J. Anim. Sci. 62:1353-1362.

Gerken, H. J. and W.H. McClure. 1979. Value of supplemental concentrate with and without monensin for wintering light calves on stockpiled fescue. Research Division Report 175 pg 127-129. Virginia Polytechnic Institute and State University, Blacksburg.

Gerrish, J.R., P.R. Peterson, C.A. Roberts, and J.R. Brown. 1994. Nitrogen fertilization of stockpiled tall fescue in the midwestern USA. J. Prod. Agric. 7:98-104.

Gonzalez-Padilla, E., J.N. Wiltbank and G.D. Niswender. 1975. Puberty in beef heifers. I. The interrelationship between pituitary, hypothalamic and ovarian hormones. J. Anim. 
Sci. 40:1091.

Griffith, M., and P.M.G. Hutton. 1936. The wintering of sheep on temporary grasses. Welsh J. Agric. 12:126-130.

Hall, M. H. 1994a. Orchardgrass. Agronomy Facts \#25. Pennsylvania State College of Agricultural Science.

Hall, M. H. 1994d. Tall Fescue. Agronomy Facts \#28. Pennsylvania State College of Agricultural Sciences.

Hall, M.H, and J. Jung. 1993. Extending the grazing season. Agronomy Facts \#41. Pennsylvania State College of Agricultural Science.

Hammes, R.C., Jr. 1976. Beef cow and calf performance on year-round grazing systems. Proc. No. Va. Forage Conf., Middleburg, VA.

Hannaway, D.B., C. Larson, D. Myers, and M. Cool. 2004. Orchardgrass. www.forages.orst.edu.

Hannaway, D. B., C. Daly, M. Halbleib, D. James, C. P. West, J. J. Volenec, D. Chapman, X. Li, W. Cao, J. Shen, X. Shi, and S. Johnson. 2009. Development of suitability maps with examples for the United States and China. p. 33 in Tall Fescue for the Twenty-First Century. H. A. Fribourg, D. B. Hannaway, and C. P. West, ed. Monogr. No. 53. Am. Soc. Agron., Madison, WI.

Hawk, H. W., W. J. Tyler, and L. E. Cssida. 1954. Some factors affecting age at puberty in Holstein-Friesian heifers. J. Dairy Sci. 37:252.

Hayden, J. M., J. E. Wiilliams, and R. J. Collier. 1993. Plasma growth hormone, insulin-like growth factor, insulin, and thyroid hormone association with body protein and fat accretion in steers undergoing compensatory gain after dietary energy restriction. J. Anim. Sci. 71:3327-3338.

Hedtcke, J.L., D.L. Undersander, M.D. Casler, and D.K. Combs. 2002. Quality of forage stockpiled in Wisconsin. J. Range Manage. 55:33-42.

Hersom, M.J. 1999. Evaluation of year-round forage management systems for beef cattle. M.S. Thesis. Iowa State Univ., Ames.

Hitz, A. C., and J. R. Russell. 1998. Potential of stockpiled perennial forages in winter grazing systems for pregnant beef cows. J. Anim. Sci. 76:404-415.

Hornick, J. L., C. Van Eenaeme, M. Diez, V. Minet, and L. Istasse. 1998b. Different periods of feed restriction before compensatory growth in Belgian blue bulls: II. Plasma metabolites and hormones. J. Anim. Sci. 76:260-271. 
Hornick, J. L., C. Van Eenaeme, O. Gerard, I. Dufrasne, and L. Istasse. 2000. Mechanisms of reduced and compensatory growth. Domestic Anim. Endocrinol. 19:121-132.

Jensen, K. B., Johnson, D. A., Asay, K. H., and Olsen, K. C. 2002. Seasonal-accumulated growth and forage quality of range grasses for fall and winter grazing. Can. J. Plant Sci. 82:329336.

Ju, H. J., N. S. Hill, T. Abbott, and K. T. Ingram. 2006. Temperature influences on endophyte growth in tall fescue. Crop Science 46:404-416.

Kadokawa H., M. Matsui, K. Hayashi, N. Matsunaga, C. Kawashima, T. Shimizu, K. Kida, and A. Miyamoto. 2008. Peripheral administration of kisspeptin-10 increases plasma concentrations of GH as well as LH in prepubertal Holstein heifers. J. Endocrinol. 196:331-334.

Kallenbach, R.L., G.J. Bishop-Hurley, M.D. Massie, M.S. Kerley, and C. A. Roberts. 2003 b. Stockpiled annual ryegrass for winter forage in the lower Midwestern USA. Crop Sci. 43: 1414-1419.

Kamalzadeh, A., W. J. Koops, and J. van Bruchem. 1998a. Feed quality restriction and compensatory growth in growing sheep: modeling changes in body dimensions. Livest. Prod. Sci. 5:57-67.

Kamalzadeh, A., W. J. Koops, J. van Bruchem, and G. A. Bangma. 1998b. Effects of duration of feed quality restriction on body dimensions in lambs. J. Anim. Sci. 76:735-742.

Klopfenstein, T. J., D. J. Jordon, Ivan Rush, and Todd Milton.1999. Predicting amount of compensatory gain. Nebraska Beef Cattle Report. MP 71-A:26-28. Lincoln, NE.

Klosterman, E.W. and C.F. Parker. 1976. Effect of size, breed and sex upon feed efficiency in beef cattle. Ohio Agric. Res. And Dev. Center Res. Bull. 1088. pp 1-39.

Kusina, N. T., T. Chinuwo, H. Hamudikuwanda, L. R. Ndlovu, and S. Muzanenhamo. 2001. Effects of different dietary energy level intakes on efficiency of estrus synchronization and fertility in Mashona goat does. Small Rum. Res. 39:283-288.

Lesmeister, J. L., P. J. Burfening, and R. L. Blackwell. 1973. Date of first calving in beef cows and subsequent calf production. J. Anim. Sci. 36:1.

Lynch, J.M., G.C. Lamb, B.L. Miller, R.T. Brandt, Jr., R.C. Cochran, and J.E. Minton. 1997. Influence of timing of gain on growth and reproductive performance of beef replacement heifers. J. Anim. Sci. 75:1715-1722.

Maes, M., L.E. Underwood, and J.M. Ketelslegers. Plasma somatomedin-C in fasted and refed rats: close relationships with changes in liver somatogenic but not lactogenic binding sites. J Endocrinol 1983;97:243-52. 
Martin, J.H. and W.H. Leonard. 1967. Principles of Field Crop Production. The Macmillan Company, New York.

Martin, J. L., K. W. Creighton, J. A. Musgrave, T. J. Klopfenstein, R. T. Clark, D. C. Adams, and R. N. Funston. 2008. Effect of prebreeding body weight or progestin exposure before breeding on beef heifer performance through the second breeding season. J. Anim. Sci. $86: 451-459$.

Matches, A.G., and J.C. Burns. 1995. Systems of grazing management. p. 179-192. In R.F Barnes et al. (ed.) Forages. Volume II: The science of grassland agriculture. Iowa State Univ. Press, Ames.

McClure, W.H., J.P. Fontenot and H.J. Gerken, Jr. 1977. Stockpiled fescue for wintering beef calves. Research Division Report 172 pg 79-81. Virginia Polytechnic Institute and State University, Blacksburg.

McLaren, J.B., R.J. Carlisle, H.A. Fribourg, and J.M. Bryan. 1983. Bermudagrass, tall fescue, and orchardgrass pasture combinations with clover or $\mathrm{N}$ fertilization for grazing steers. I. Forage growth and consumption, and animal performance. Agron. J. 75:587-592.

Menge, A. C., S. E. Mares, W. J. Tyler, and L. E. Casida. 1960. Some factors affecting age at puberty and the first 90 days of lactation of Holstein heifers. J. Dairy Sci. 4331099.

Meyer, A.M. ,M. S. Kerley , R. L. Kallenbach , and T. L. Perkins. 2009. Comparison of Grazing Stockpiled Tall Fescue Versus Feeding Hay With or Without Supplementation for Gestating and Lactating Beef Cows During Winter. The Professional Animal Scientist 2 5 ( 2009 ):449-458.

Mitchell, A.D. 2007. Impact of Research with Cattle, Pigs, and Sheep on Nutritional Concepts: Body Composition and Growth. Symposium: History of Nutrition: Impact of Research with Cattle, Pigs, and Sheep on Nutritional Concepts. . J. Nutr. Mar;137(3):711-4.

Myers, W.M. 1962. Orchardgrass. In: H.D. Hughes, M.E. Heath, and D.S. Metcalfe (Ed) Forages. The Iowa State University Press. Ames, Iowa.

Mulliniks, J. T., D. E. Hawkins, K. K. Kane, S. H. Cox, L. A. Torell, E. J. Scholljegerdes, and M. K. Petersen. 2012. Metabolizable protein supply while grazing dormant winter forage during heifer development alters pregnancy and subsequent in-herd retention rate. J. Anim. Sci. 90:In Review.

Ortigues I., and D. Durand. Adaptation of energy metabolism to undernutrition in ewes. contribution of portal-drained viscera, liver and hindquarters. Br J Nutr 1995;73:209 -26.

Owens, F.N., P. Dubeski, and C. F. Hanson. 1993. Factors that alter the growth and development of ruminants. J. Anim. Sci. 71:3138-3150. 
Paquay, R., R. De Baere, and A. Lousse. The capacity of the mature cow to lose and recover nitrogen and the significance of protein reserves. Br J Nutr 1972;27:27-37.

Patterson, D.J., L.R. Corah, G.H. Kiracofe, J.S. Stevenson, and J.R. Brethour. 1989. Conception rate in Bos Taurus and Bos Indicus crossbred heifers after postweaning energy manipulation and synchronization of estrus with melengestrol acetate and fenprostalene. J. Anim. Sci. 67:1138-1147.

Patterson, D. J., L. R. Corah, and J. R. Brethour. 1990. Response of prepubertal Bos taurus and Bos indicus $x$ Bos taunu heifers to melengestrol acetate with or without gonadotropinreleasing hormone. Theriogenology 333381

Patterson, D.J., R.C. Perry, G.H. Kiracofe, R.A. Bellows, R.B. Staigmiller, and L.R. Corah. 1992. Management considerations in heifer development and puberty. J. Anim. Sci. 70:4018-4035.

Plasse, D., A. C. Warnick, and M. Koger. 1968. Reproductive behavior of Bos indicus females in a subtropical environment. I. Puberty and ovulation frequency of Brahman and Brahman x British heifers. J. Anim. Sci. 27:94.

Prigge, E.C., W.B. Bryan, and E.S. Goldman-Innis. 1999. Early- and late-season grazing of orchardgrass and fescue hayfields overseeded with red clover. 103 Agron. J. 91: 690-696.

Rayburn, E.B., R.E. Blaser, and D.D. Wolf. 1979. Winter tall fescue yield and quality with different accumulation periods and N rates. Agron. J. 71:959-963.

Rayburn, E.B., R.E. Blaser, and J.P. Fontenot. 1980. In vivo quality of tall fescue as influenced by season, legumes, age and canopy strata. Agron. J. 72:872-876.

Rayburn, E. 2000. Extending grazing season reduces costs. WVU Extension Publication 8/00. http://www.wvu.edu/ agexten/forglvst/extendin.htm.

Rayburn, E.B. (editor). 2007. Forage Utilization for Pasture Based Livestock Production. NRAES - Book 173; Chapter 6 - Deferred Grazing to Extend the Grazing Season: p. 8296. PALS Publishing, Ithaca, New York.

Riesterer, J.L., D.J. Undersander, M.D. Casler, and D.K. Combs. 2000. Forage yield of stockpiled perennial grasses in the upper Midwest USA. Agron. J. 92:740-747.

Reynolds, W. L., T. M. DeRouen and J. W. High, Jr. 1963. The age and weight at puberty of Angus, Brahman, and Zebu cross heifers. J. Anim. Sci. 22:243 (abstr.).

Roberts, A.J., T.W. Geary, E.E. Grings, R.C. Waterman and M.D. MacNeil. 2009. Reproductive performance of heifers offered ad libitum or restricted access to feed for a one hundred forty-day period after weaning. J. Anim. Sci. 87:3043-3052. 
Roberts, A J., R. A. Nugent, III, J. Klindt, and T. G. Jenkins. 1997. Circulating insulin-like growth factor I, insuline-like growth factor binding proteins, growth hormone, and resumption of estrus in postpartum cows subjected to dietary energy restriction. J. Anim. Sci. 75:1909-1917.

Sahlu, T., S. P. Hart, and A. L. Goetsch. 1999. Effects of level of feed intake on body weight, body components, and mohair growth in Angora goats during realimentation. Small Rum. Res. 32:251-259.

Scaglia,G., Swecker Jr. W. S., Fontenot, J. P., Fiske, D., Fike, J.H., Abaye, A.O., Clapham,W. and Hall, J.B. 2008. Forage systems for cow-calf production in the Appalachian region. J. Anim. Sci. 86:2032-2042.

Schillo, K. K., D. J. Dierschke and E. R. Hauser. 1982. Influences of month of birth and age on patterns of luteinizing hormone secretion in prepubertal heifers. Theriogenology. 18:593598.

Schillo, K., J. B. Hall and S. M. Hileman. 1992. Effects of Nutrition and season on the onset of puberty in the beef heifer. J. Anim. Sci. 70:3994-4005.

Senger, P.L. 1999. The luteal phase of the estrous cycle. In: Pathways to Pregnancy and Parturition, Current Conceptions, Inc., Pullman, WA, pp. 149-166.

Sheehan, W., J.P. Fontenot, and R.E. Blaser. 1985. In-vitro dry matter digestibility and chemical composition of autumn-accumulated tall fescue, orchardgrass and red clover. Grass and Forage Sci. 40:317-322.

Short, R. E. and R.A. Bellows. 1971. Relationships among weight gains, age at puberty and reproductive performance in heifers. J. Anim. Sci. 32:127-131.

Short, R.E., R.A. Bellows, J.B. Carr, R.B. Stagmiller, and R.D. Randel. 1976. Induced or synchronized puberty in heifers. J. Anim. Sci. 43:1254.

Taylor, T.H., and W.C. Templeton, Jr. 1976. Stockpiling Kentucky bluegrass and tall fescue forage for winter pasturage. Agron. J. 68:235-239.

Thomas G.B., J.B. Mercer, T. Karalis, A. Rao, J.T. Cummins, and I.J. Clarke. Effect of restricted feeding on the concentrations of growth Hormone $(\mathrm{GH})$, gonadotropins, and prolactin (PRL) in plasma, and on the amounts of messenger ribonucleic acid for $\mathrm{GH}$, gonadotropin subunits, and PRL in the pituitary glands of adult ovariectomized ewes. Endocrinology 1990;126:1361-67.

Thornton, R. F., R. L. Hood, P. N. Jones, and V. M. Re. 1979. Compensatory growth in sheep. Aust. J. Agric. Res. 30:135-151.

Tortonese, D. J., and E. K. Inskeep. 1992. Effects of melatonin treatment on the attainment of 
puberty in heifers. J. Anim. Sci. 70:2822-2827.

Tudor, G. D., D. W. Utting, and P. K. O'Rourke.1980. The effect of pre- and post-natal nutrition on the growth of beef cattle. III. The effect of sevier restriction in early post-natal life on the development of body components and chemical composition. Aust. J. Agric. Res. 31:179-192.

VanKeuren, R.W. 1970. All-season grazing for beef cows. Ohio Agric. Boulder, CO. Res. Dev. Cent. Res. Summary 43:1-6.

Van Soest, P.J. 1994. Nutritional Ecology of the Ruminant. Cornell University Press, Ithaca, NY.

Warnick, A.C., W.C. Burns, M. Kogar and M.W. Hazen. 1956. Puberty in English, Brahman and crossbred breeds of beef heifers. Proc. 53rd Southern Agric. Workers.

Waters, H.J. 1908. The capacity of animals to grow under adverse conditions. Proc Soc Prom Agric Sci, NY. 29:71-96.

Wester, T. J., R. A. Britton, T. J. Klopfenstein, G. A. Ham, D. T. Hickok, and C. R. Krehbiel. 1995. Differential effects of plane of protein or energy nutrition on visceral organs and hormones in lambs. J. Anim. Sci. 73:1674-1688.

Whittier, J. C., J. Berardinelli, and L. Anderson. 2008. Understanding puberty and postpartum anestrus. In Proceedings, Applied Reproductive Strategies in Beef Cattle. Fort Collins, $\mathrm{CO}$.

Williams, G. L., and M. Amstalden. 2010. Understanding postpartum anestrus and puberty in the beef female. In Proceedings, Applied Reproductive Strategies in Beef Cattle. San Antonio, TX.

Willms, W. D., Rode, L. M., and Freeze, B. S. 1993. Winter performance of Hereford cows on fescue prairie and in drylot as influenced by fall grazing. Can. J. Anim. Sci. 73: 881-889.

Wiltbank, J. N., K.E. Gregory, L.A. Swiger, J.E. Ingalls, J.A. Rothlisberger, and R.M. Koch. 1966. Effects of heterosis on age and weight at puberty in beef heifers. J. Anim. Sci. 25:744-751.

Wiltbank, J.N., C.W. Kasson, and J.E. Ingalls. 1969. Puberty in crossbred and straightbred beef heifers. J. Anim. Sci. 29:602-605.

Wiltbank, J. N., S. Roberts, J. Nix, and L. Rowden. 1985. Reproductive performance and profitability of heifers fed to weigh 272 or $318 \mathrm{~kg}$ at the start of the first breeding season. J. Anim. Sci. 60:25-34.

Wolf, D., and von Boberfeld, W. Opitz. 2003. Effects of nitrogen fertilization and date of utilization on the quality and yield of tall fescue in winter. J. Agron. Crop Sci. 189:47-53. 
Yambayamba, E. S. K., M. A. Price, and G. R. Foxcroft. 1996. Hormonal status, metabolic changes, and resting metabolic rate in beef heifers undergoing compensatory growth. J. Anim. Sci. 74:57-69.

“2011 Farm Characteristics Summary” USDA Economic Research Service, 2012

“2011 Farm Production Expenditures Annual Summary” USDA-NASS, 2012. 


\section{Chapter 2}

Herbage mass, forage quality, and botanical composition of mixed cool season naturalized pastures in response to two fall stocking rates

\footnotetext{
${ }^{1}$ Formatted for submission to Forage and Grazinglands.
} 


\title{
Herbage mass, forage quality, and botanical composition of mixed cool season naturalized pastures in response to two fall stocking rates.
}

\author{
B.L. Bailey, T.C. Griggs, E.B. Rayburn and K. M. Krause \\ Divisions of Animal and Nutritional Sciences and Plant and Soil Sciences, West Virginia \\ University, Morgantown, $W V$.
}

\begin{abstract}
The potential of tall fescue (Schedonorus phoenix) and orchardgrass (Dactyalis glomerata) as stockpiled forages have been extensively documented; however, there is limited information on the characteristics of other species, especially complex mixtures of cool-season naturalized pastures. Therefore, a 3-year study was conducted to assess the herbage mass, forage quality, and botanical composition characteristics of mixed cool-season naturalized pastures in response to two stocking rates which were based on daily herbage allowances of $3.5 \%$ (LO) or 7.0\% (HI) of heifer BW. Averaged over the 3 years, stocking rate (heifers/ha) for the entire pasture area including unoccupied paddocks during the fall grazing period was 6.0 for the LO treatment and 3.2 for the HI treatment. Initial herbage mass and botanical composition was determined at the end of the stockpiling period. Herbage mass and forage quality samples were taken throughout the fall grazing period at intervals of 11 to 19 days. There were no treatment effects for changes in botanical composition. There was a significant effect of year on total legume percentage, which increased from $6 \%$ to $31 \%(P<0.05)$. Herbage mass declined more quickly in year 3 than in years 1 and $2(P<0.05)$. This rapid decline in year 3 is most likely due to the high percentage of legumes present. As the fall grazing period progressed, $\mathrm{CP}$ content and IVTDMD declined and NDF content increased. This study demonstrated that mixed coolseason naturalized pastures can be utilized for stockpiling and grazed intensively without detrimental effects to subsequent stockpiling periods.
\end{abstract}




\section{Introduction}

The ability to meet the nutritional needs of grazing cattle throughout the year, with little or no reliance on harvested feed or supplements is the greatest challenge in pasture-based systems. Forage systems in Appalachia are based on cool season grasses such as tall fescue, orchardgrass, white clover (Trifolium repens L.), and red clover (Trifolium pratense). The two biggest challenges in constructing a balanced, year-round pasture-based system are maintaining adequate forage quantity and quality in mid-summer and extending the grazing season as long as possible into fall and early winter.

Stockpiling of forages during late summer and fall for grazing has been shown to be an effective practice to extend the grazing season and reduce the amount of stored feeds needed $(1,11)$. A variety of factors including climate, plant species, accumulation period, and fertilization timing and rate affect the quantity and quality of stockpiled forages. Among the species used for stockpiling, the most commonly studied is tall fescue. Research has demonstrated that tall fescue has the ability to maintain quality throughout the fall and early winter better than other grasses. Less is known about the stockpiling characteristics of other grasses and legumes, especially naturalized pastures containing complex mixtures.

The objective of this study was to evaluate the nutritive quality, herbage mass, and botanical composition of cool-season mixed grass-legume naturalized pastures in response to two stocking rates during the fall grazing period.

\section{Pastures and Treatments}

This study was part of a larger study (3) which took place from August 2009 to August 2012 at the West Virginia University Agricultural and Forestry Experiment Station Reedsville 
Farm in Preston County in Northern WV (530 m elevation; 39 30’ N, 79 50’ W). The experiment was replicated over 3 consecutive years and three 5-hectare fields were selected as blocks in a randomized complete block design with 3 field replications of 2 treatments. All fields had been in long-term hay and pasture production and contained predominantly naturalized perennial cool-season species. The soil types were silt loams with Rayne, Ernest, and Gilpin being most prevalent. Soil test results from sampling to a 5-8 $\mathrm{cm}$ depth over the 3 year experimental period were $\mathrm{pH}$ of $6.2,25 \mathrm{ppm} \mathrm{P}$, and $189 \mathrm{ppm} \mathrm{K}$.

Spring-born weanling beef heifers $(n=72,64$, and 67 in years $1-3$, respectively) with a mean body weight (BW) of $246 \mathrm{~kg}$ were randomly placed on one of two treatments. Treatments consisted of two stocking rates which were based on daily herbage dry matter (DM) allowances of $3.5 \%$ (LO) or $7.0 \%(\mathrm{HI})$ of initial heifer BW (not adjusted thereafter). Averaged over the 3 years, stocking rate (heifers/ha) for the entire pasture area including unoccupied paddocks during the fall grazing period was 6.0 for the LO treatment and 3.2 for the HI treatment. Stocking density ( $\mathrm{kg} / \mathrm{ha}$ ) for only the paddock area being grazed at any point in time during the fall grazing period was 26,813 and 13,488 (year 1), 19,991 and 11,080 (year 2), and 29, 270 and 15, 118 (year 3) for LO and HI treatments, respectively.

Stockpiling of pastures began in mid-late August of each year. Urea $(0.46 \mathrm{~N})$ was applied in August at 80-100 kg N/ha. Pastures were allowed to regrow without utilization for the remainder of the growing season, which ended in late October to early November. Fall grazing treatments began in early November and continued until snow conditions prevented grazing or pastures had been fully consumed. Herbage allowances were assigned by delineating appropriate paddock areas with portable electric fencing. Each treatment group was given a new paddock area every 3-5 days in a strip-grazing pattern without back fencing, allowing animals to 
return to a permanent watering point. Heifers grazed for 35 days during the fall grazing period in year 1, 58 days in year 2 and 68 days in year 3.

\section{Forage Measurements}

Forage mass of each experimental unit was determined at the end of each growing season (October 26, 2009, October 29, 2010 and October 21, 2011) and every 11-19 days thereafter in un-grazed paddocks, depending on environmental conditions, during the fall grazing period. Forage mass was determined by taking at least 100 rising plate meter readings. An Ellinbank type rising plate meter with $0.32 \times 0.32$ meter square aluminum plate was used (9). It was obtained from the University of Missouri Research Reactor Center (MURR) 1513 Research Park Drive Columbia, MO 65211-3400. The rising plate meter readings were calibrated by clipping forage within square quadrats $\left(0.1 \mathrm{~m}^{2}\right)$ to nearly soil surface (approximately $1 \mathrm{~cm}$ ) using forged grass shears. The clipped samples were dried at $60^{\circ} \mathrm{C}$ for $\geq 48$ hours and weighed. Regression was used to develop herbage mass equations relating the clipped forage samples with the rising plate meter readings. For the fall grazing period each year, a final herbage mass prediction model was selected following analysis of the following alternatives: 1) Simple linear regression with yintercept; 2) simple linear regression with intercept forced through origin; 3) quadratic regression with y-intercept; and 4) quadratic regression with intercept forced through origin. Final regression equations shown in Table 1 were selected on the basis of significance level of yintercept, $\mathrm{r}^{2}$ value, and root MSE value.

Botanical composition of pastures was determined in late October each year using the dry-weight-rank method (13). Measurements were obtained within a $0.1 \mathrm{~m}^{2}$ quadrat and 55 data points were assessed for each experimental unit. 
To determine the nutritive value of the pastures, forage samples were taken every two weeks during the fall grazing period, depending on weather conditions. For simplicity, sampling periods are defined as early (1 to 2 weeks after treatment initiation), mid (middle of grazing period) and late (1 to 2 weeks prior to treatment termination). Forage samples were analyzed in duplicate. Partial DM was determined by oven drying at $60^{\circ} \mathrm{C}$ for $48 \mathrm{~h}$. Dried samples were ground though a 1-mm screen in a Wiley mill (Arthur H. Thomas, Philadelphia, PA). Analytical lab $\mathrm{DM}$ of the forages was determined by oven drying at $100^{\circ} \mathrm{C}$ for $24 \mathrm{~h}$ (2). Neutral detergent fiber (NDF) was determined using an Ankom 200 Fiber Analyzer (Ankom Technology Corp, Macedon, NY). Heat-stable $\alpha$-amylase and sodium sulphite treatments (15) were used to obtain NDF. Crude protein (CP) content was analyzed according to AOAC (1995) using an automated Tecator digestion system (Tecator Inc., Herndon, VA). Total digestible nutrient (TDN) content of the pasture was calculated using the NRC (2001) summative equation (16). Near-infrared reflectance spectroscopy (NIRS) was used to determine in vitro true dry matter digestibility (IVTDMD48) of pasture samples as described in more detail in Bailey et al., (3).

\section{Statistical Analysis}

Data were analyzed using the MIXED procedure of SAS (SAS Inst. Inc., Cary, NC). Forage quality, herbage mass, and botanical composition data were analyzed for treatment, year, and treatment $\mathrm{x}$ year interaction. Year and interactions with year were considered fixed effects so that the effects of multiple grazing years could be assessed. Block and its' interactions were considered random effects. Sampling period data were analyzed as repeated measures. Variancecovariance matrix structures were selected for each model based on the lowest Akaike Information Criterion fit statistic and nonsignificant interactions were removed from the models $(P>0.85)$. Significant differences were defined as $P \leq 0.05$ and tendencies at $P \leq 0.10$. To 
determine regression equations for prediction of herbage mass the NCSS 2000 Statistical System was used (10).

\section{Evaluation of Botanical Composition, Herbage Mass, and Forage Quality}

\section{Botanical Composition}

Botanical composition is described in Tables 2 and 3. Herbage mass averaged across all grazing events of the entire experiment (2009-2012) was composed of orchardgrass (Dactylis glomerata; 30.5\%), tall fescue (Schedonorus phoenix; 14.1\%), white clover (T. repens; 9.9\%), red clover (Trifolium pretense; 9.5\%), narrowleaf plantain (Plantago lanceolata; 9.0\%) and quackgrass (Elymus repens; 8.5\%). There were no effects of HI vs. LO treatments on changes in botanical composition. There was no significant effect of year on percentage of total grass species in the pasture; however, $\%$ grass tended to decrease over the 3 -year period from $70 \%$ to $45 \%(P=0.10)$. There tended to be a significant effect of treatment on percentage of nonlegume forbs $(P=0.06)$. In the HI treatment, non-legume forbs decreased $14 \%$ from year 1 to year 3 and increased $21 \%$ in the LO treatment from year 1 to year 3.

Total legume percentage increased from $6 \%$ to $31 \%(P<0.05)$ from year 1 to year 3 . Of the legumes, white clover increased the most over the 3 -year period (1\% to $19 \%)$ and red clover increased from $5 \%$ to $12 \%$. The large increase in legumes seen from year 1 to year 3 was most likely a result of above average precipitation during the winter of year 1 and the spring through fall periods of year 2 (Table 4). Also, of the legumes, there was a numerically higher percentage of white clover vs. red clover in the LO treatments by year-3 (22\% vs. $14 \%)$. When pastures are rotationally grazed to short residue heights, clover regrowth is favored over grass regrowth (5). Red clover is less tolerant to close and frequent grazing than white clover because it has more growing points and leaves in the upper canopy resulting in the loss of a higher proportion of the 
growing points and leaf area at grazing (4). Brummer and Moore (6) demonstrated that white clover persisted better than alfalfa (Medicago sativa L.), birdsfoot trefoil (Lotus corniculatus L.), and red clover, with no loss of stand after two grazing years.

\section{Herbage Mass}

Beginning herbage mass (data not shown) for the fall grazing period was $3,884 \mathrm{~kg} / \mathrm{ha}$ for both $\mathrm{HI}$ and LO treatments in year 1. In year 2, beginning herbage mass was 2,941 and 3,046 $\mathrm{kg} / \mathrm{ha}$ for LO and $\mathrm{HI}$ treatments, respectively. In year 3, beginning herbage mass was 4,066 and $3,677 \mathrm{~kg} / \mathrm{ha}$ for $\mathrm{LO}$ and $\mathrm{HI}$ treatments, respectively. Rainfall during the spring and summer of year 2 was generally below average. This trend continued into the fall forage accumulation period of year 2 with rainfall amounts in July, August and September below average which contributed to lower herbage mass amounts at the end of the fall stockpiling period in year 2 . This resulted in a shorter grazing period (58 days), compared to year 3 (68 days). Rainfall was above average in March and April, below average in May and June and above average July and August and continuing through the accumulation period of year 3. These above average rainfall amounts contributed to more stockpiled forage in year 3 than years 1 and 2 (Table 4). Mean beginning herbage mass in year 1 was similar to year $3(3,884 \mathrm{~kg} / \mathrm{ha} v \mathrm{vs.} 3,872 \mathrm{~kg} / \mathrm{ha}$, respectively); however, above average snowfall in December year 1 ended grazing early. This resulted in only 35 days of grazing in the fall of year 1 compared to 68 days of grazing in year 3 .

Average herbage mass data for the fall grazing period is presented in Figure 1, whereas herbage mass for the 3 fall sampling periods is presented in Figure 2. There was a significant year $\mathrm{x}$ treatment interaction on mean herbage mass during the fall grazing period $(P<0.01)$. Mean herbage mass was higher in the HI treatments than in the LO treatments in all years except year 1 when herbage mass was higher in the LO treatment; however this difference was only 47 
$\mathrm{kg} / \mathrm{ha}$. Mean herbage mass was similar in years 1 and 3; however, in year 2 herbage mass was much lower. This is most likely because beginning herbage mass in year 2 was less than in years 1 and 3 due to below average precipitation during the stockpiling period.

In each year, herbage mass declined throughout the fall grazing period. There was a significant year $\mathrm{x}$ sampling period interaction $(P=0.02)$. In years 1 and 2 , herbage mass declined steadily in both $\mathrm{HI}$ and $\mathrm{LO}$ treatments. From early in the fall grazing period to the middle of the period herbage mass declined $9.1 \%$ and $8.6 \%$ (year 1 ) and $10.4 \%$ and $7.0 \%$ (year 2) for LO and $\mathrm{HI}$ treatments, respectively. From the middle of the fall grazing period to late in the period, herbage mass declined $10.0 \%$ and $8.5 \%$ (year 1) and $9.7 \%$ and $8.9 \%$ (year 2) for LO and $\mathrm{HI}$ treatments, respectively. In year 3, however, herbage mass declined at a much faster rate than in years 1 and 2 from early in the fall period to the middle portion of the period $(15.2 \%$ for both LO and HI treatments). This rapid decline in year 3 was most likely due to the high percentage of legumes present. Legumes are generally not suited for stockpiling and grazing in late fall or winter due to leaf loss. Although leaf retention time is variable, legumes tend to lose their leaves quickly following hard frosts and with advancing maturity and therefore DM losses are large (12).

\section{Forage Nutritive Value of Pastures}

Nutritional composition of pastures is presented in Table 5. There was no treatment effect, but there was a significant year effect $(P=0.05)$ for $\mathrm{CP} \%$ during the fall grazing period. Mean CP \% was $15.8 \%$ (year 1), 19.4\% (year 2,) and 17.0\% (year 3). After year 1, mean CP\% increased, most likely due to the increase in clover observed in all fields. Pastures with legumes have greater $\mathrm{CP}$ content and increased rate of digestibility, resulting in greater forage intake and animal performance (14). Throughout the fall grazing period, $\mathrm{CP}$ declined in both treatments $(P$ 
$=0.003)$ (Figure 3). During the early portion of the fall grazing period, $\mathrm{CP}$ was $18.3 \%$ and from there it declined to $18.1 \%$ (mid grazing) and $16.2 \%$ (late grazing).

There was a significant year effect for NDF concentration $(P<0.001)$. Mean NDF concentrations during the fall were 52.7\% (year 1), 49.2\% (year 2), and 51.4\% (year 3). Also, there tended to be an effect of treatment on NDF $(50.7 \%$ for $\mathrm{HI}$ and $51.5 \%$ for LO; $P=0.06)$. Since there was a higher concentration of legumes in LO vs. HI treatments and in year 3 compared to years 1 and 2, these results conflict with previous research which demonstrated that legumes usually display lower concentrations of NDF fiber and greater digestibility than grasses $(8,18)$. Reasons for the increase in NDF in year 3 and in $\mathrm{LO}$ vs. HI treatments are not well understood at this time. From the beginning of treatment initiation to late into fall grazing NDF increased in each year. There was a significant year $\mathrm{x}$ sampling period interaction $(P=0.002)$ because in year 2, at treatment initiation, NDF was lower and increased more rapidly than in years 1 and 3 (Figure 4). Precipitation was well below average during the stockpiling and grazing period in year 2 which could have had an effect on the change in NDF concentration.

There was no treatment, year, or treatment $\mathrm{x}$ year interaction for IVTDMD; however, there was a significant year $\mathrm{x}$ sampling period interaction $(P=0.009)$. From treatment initiation through late grazing IVTDMD declined in all years of the study; however, IVTDMD declined more rapidly from mid to late grazing in year 1 than in years 2 and 3 (Figure 5). Declines in nutritive value during the fall and winter are generally associated with normal leaf aging and senescence in the canopy, which if associated with freezing and frost intensity, contribute to declining nutritive value due to release of soluble nutrients which are either translocated or leached (7). 


\section{Summary and Conclusions}

Overall, we found that there was no significant effect of HI vs. LO stocking rates on botanical composition, herbage mass, or forage quality. Average stockpiled herbage mass in the pastures compared favorably with yields of tall fescue and orchardgrass. Mean December yield of the stockpiled forage across all years was 2,664 $\mathrm{kg} \mathrm{DM} / \mathrm{ha}$ (LO) and 2,747 $\mathrm{kg} \mathrm{DM} / \mathrm{ha}$ (HI) which was less than tall fescue, $2,783 \mathrm{~kg} \mathrm{OM} / \mathrm{ha}$, but greater than orchardgrass, $2,567 \mathrm{~kg} \mathrm{OM} / \mathrm{ha}$, reported by Riesterer (17). Distribution of DM yield and botanical composition from year 1 to 3 and throughout the fall grazing periods was influenced primarily by climatic conditions and grazing management (stocking rate). Nutritive content of the pastures was adequate to meet the requirements of beef heifers. This study demonstrated that mixed cool-season naturalized pastures can be utilized for stockpiling and grazed intensively without detrimental effects to subsequent stockpiling periods. 


\section{REFERENCES}

1. Allen, V.G., J.P. Fontenot, D.R. Notter, and R. C. Hammes, Jr. 1992. Forage systems for beef production from conception to slaughter: I. Cow-calf production. J. Anim. Sci. 70:576-587.

2. Association of Official Analytical Chemists. 1995. Official Methods of Analysis. Vol I. 16thed. AOAC, Arlington, VA.

3. Bailey, B.L., T.C. Griggs, E.B. Rayburn, and K.M. Krause. 2013. Beef heifer growth and reproductive performance responses following two levels of stockpiled fall forage allocation. In preparation for submittal to J.Anim. Sci.

4. Barnes, R.F., T.H. Taylor. 1985. Grassland Agriculture and Ecosystem Concepts. Pages: 1220 in Forages: The Science of Grassland Agriculture. 4th edition. 1985. edited by Maurice E. Heath, Robert F. Barnes, Darrel S. Metcalfe. The Iowa State University Press.Ames, Iowa.

5. Blaser, R. E., R. C. Hammes Jr., J. P. Fontenot, H. T. Bryant, C. E. Polan, D. D. Wolf, E. S. McClaugherty, R. G. Kline, and J. S. Moore. 1986. Forage-animal management system. Pages 86-87 in Virginia Agric. Exp. Sta. Bull. Virginia Polytech. Inst. and State Univ., Blacksburg.

6. Brummer, C.E., and K.J. Moore. 2000. Persistence of perennial cool-season grass and legume cultivars under continuous grazing by beef cattle. Agron. J. 92:466-471.

7. Burns, J. C., and D.S. Chamblee. 2000. Summer accumulation of tall fescue at low elevations in the Piedmont: I. Fall yield and nutritive value. Agron. J. 92:211-216.

8. Buxton, D.R., and M.R. Brasche. 1991. Digestibility of structural car bohydrates in coolseason grass and legume forages. Crop Sci. 31:1338-1345.

9. Earle, D.F. and A. A. McGowan. 1979. Evaluation and calibration of an automated rising plate meter for estimating dry matter yield of pasture. Aust. J. Exp. Agric. Anim. Husb. 19: 337-343.

10. Hintze, J. L. 1998. NCSS 2000 Statistical System. Number Cruncher Statistical Systems, Kaysville, UT. 84037.

11. Kallenbach, R.L., G.J. Bishop-Hurley, M.D. Massie, M.S. Kerley, and C. A. Roberts. 2003b. Stockpiled annual ryegrass for winter forage in the lower Midwestern USA. Crop Sci. 43: 1414-1419.

12. Matches, A.G., and J.C. Burns. 1995. Systems of grazing management. p. 179-192. In R.F Barnes et al. (ed.) Forages. Volume II: The science of grassland agriculture. Iowa State Univ. Press, Ames. 
13. Mannetje, L.T., and K.P. Haydock. 1963. The dry-weight rank method for the botanical analysis of pasture. J. British Grassland Soc. 18:268-275.

14. Marten, G.C. 1985. Nutritional value of the legume in temperate pastures of the U.S. p. 204-212. In R.F. Barnes et a (ed.) Forage legumes for energy-efficient animal production. Proc. Trilateral Workshop, Palmerston, North, NZ. 30 Apr.-4 May 1984. USDA, ARS, Washington, D.C.

15. Mertens D.R. 2002. Gravimetric determination of amylase-treated neutral detergent fibre in feeds with refluxing beakers or crucibles: collaborative study. J. Assoc. Off. Assoc. Chem. Int., 85, 1217-1240.

16. National Research Council. 2001. Nutrient Requirements of Dairy Cattle. (7th Rev Ed.). Natl. Acad. Sci., Washington, DC.

17. Riesterer, J.L., D.J. Undersander, M.D. Casler, and D.K. Combs. 2000b. Forage yield of stockpiled perennial grasses in the upper-Midwest USA. Agron. J. 92:740-747.

18. Waldo, D.R., \& Jorgensen, N.A. 1981. Forage for high animal production: nutritional factors and effects of conservation. J. Dairy Sci., 64: 1207. 
Table 1. Regression equations relating clipped forage samples herbage mass with rising plate meter readings for the fall grazing period.

\begin{tabular}{ccccccc} 
Year & $\mathrm{n}$ & Equation & $\begin{array}{c}P \text {-value of } \mathrm{y}- \\
\text { intercept }^{\mathrm{a}}\end{array}$ & $P$-value slope & Root MSE & $\mathrm{r}^{2}$ \\
\hline 1 & 96 & $\mathrm{y}^{\mathrm{b}}=128 \mathrm{x}^{\mathrm{c}}+1410$ & $<0.01$ & $<0.001$ & 1450 & 0.27 \\
2 & 59 & $\mathrm{y}^{\mathrm{b}}=228 \mathrm{x}^{\mathrm{c}}$ & $(0.44)$ & $<0.001$ & 1107 & 0.92 \\
3 & 36 & $\mathrm{y}^{\mathrm{b}}=195 \mathrm{x}^{\mathrm{c}}$ & $(0.07)$ & $<0.001$ & 1875 & 0.89
\end{tabular}

\footnotetext{
${ }^{a}$ Significance level of y-intercept that was kept or dropped due to significance level in original model; ( ) indicates yintercept was dropped. If $P$-value of intercept term was $\leq 0.05$, regression was forced through origin.

${ }^{b} \mathrm{y}=$ herbage mass $(\mathrm{kg} \mathrm{DM} / \mathrm{ha})$

${ }^{c} \mathrm{X}=$ rising plate meter height units
} 
Table 2. Percentage of grass, legume and non-legume forbs in LO and HI treatment areas for yr $1-3(\% \mathrm{DM})$.

\begin{tabular}{|c|c|c|c|c|c|c|c|c|c|c|}
\hline \multirow[b]{2}{*}{ Component } & \multicolumn{3}{|c|}{$\mathrm{HI}$} & \multicolumn{3}{|c|}{ LO } & \multirow[b]{2}{*}{ SEM } & \multicolumn{3}{|c|}{$P$ - value } \\
\hline & Yr 1 & Yr 2 & Yr 3 & Yr 1 & Yr 2 & Yr 3 & & Yr & Treatment & Yr x Treatment \\
\hline Grass, $\%$ & 66 & 59 & 49 & 75 & 63 & 41 & 7.1 & 0.10 & 0.45 & 0.09 \\
\hline Legume, \% & 5 & 23 & 26 & 7 & 19 & 36 & 4.9 & $<0.05$ & 0.42 & 0.14 \\
\hline $\begin{array}{l}\text { Non-legume } \\
\text { forbs, } \%\end{array}$ & 29 & 18 & 25 & 19 & 18 & 23 & 4.7 & 0.56 & 0.06 & 0.14 \\
\hline
\end{tabular}

a Treatments: $\mathrm{LO}=$ daily pasture DM allowance of $3.5 \%$ of $\mathrm{BW}, \mathrm{HI}=$ daily pasture allowance of $7.0 \%$ of BW. 
Table 3. Botanical composition (\% of DM) of pastures 2009-2012.

\begin{tabular}{|c|c|c|c|c|c|c|}
\hline $\begin{array}{l}\text { Year and } \\
\text { Treatment }^{\mathrm{a}}\end{array}$ & Grass & $\%$ & Legumes & $\%$ & Non-Legume Forbs & $\%$ \\
\hline \multirow[t]{3}{*}{ Yr 1 LO } & Orchardgrass & 32.4 & Red Clover & 5.7 & Narrowleaf Plantain & 5.8 \\
\hline & Tall Fescue & 17.7 & White Clover & 1.1 & Dandelion & 3.7 \\
\hline & Quackgrass & 13.6 & & & Bedstraw & 2.9 \\
\hline \multirow[t]{3}{*}{ Yr $1 \mathrm{HI}$} & Orchardgrass & 28.6 & Red Clover & 4.5 & Thistle & 9.0 \\
\hline & Smooth Bromegrass & 14.0 & White Clover & 0.9 & Narrowleaf Plantain & 8.2 \\
\hline & Quackgrass & 11.1 & & & Bedstraw & 6.3 \\
\hline \multirow[t]{3}{*}{ Yr 2 LO } & Orchardgrass & 25.2 & White Clover & 10.3 & Narrowleaf Plantain & 7.7 \\
\hline & Quackgrass & 12.8 & Red Clover & 8.7 & Broadleaf Plantain & 6.1 \\
\hline & Tall Fescue & 11.9 & & & Bedstraw & 2.5 \\
\hline \multirow[t]{3}{*}{ Yr 2 HI } & Orchardgrass & 22.7 & Red Clover & 14.2 & Narrowleaf Plantain & 7.7 \\
\hline & Tall Fescue & 17.6 & White Clover & 9.3 & Broadleaf Plantain & 4.8 \\
\hline & Kentucky Bluegrass & 7.9 & & & Bedstraw & 4.8 \\
\hline \multirow[t]{3}{*}{ Yr 3 LO } & Orchardgrass & 20.1 & White Clover & 21.6 & Narrowleaf Plantain & 13.2 \\
\hline & Tall Fescue & 12.1 & Red Clover & 14.2 & Broadleaf Plantain & 3.9 \\
\hline & Timothy & 3.6 & & & Horsenettle & 3.3 \\
\hline \multirow[t]{3}{*}{ Yr 3 HI } & Orchardgrass & 23.2 & White Clover & 16.4 & Narrowleaf Plantain & 12.7 \\
\hline & Tall Fescue & 14.2 & Red Clover & 9.8 & Bedstraw & 3.3 \\
\hline & Kentucky Bluegrass & 5.2 & & & Barnyard Grass & 2.4 \\
\hline
\end{tabular}


Table 4. Long-term monthly mean rainfall, snowfall and temperature, and departures from the long-term mean in yr $1-$ yr $3^{1}$.

\begin{tabular}{|c|c|c|c|c|c|c|c|c|c|c|c|c|}
\hline Item & Aug & Sept & Oct & Nov & Dec & Jan & Feb & March & April & May & June & July \\
\hline \multicolumn{13}{|l|}{30 yr mean } \\
\hline Rain, mm & 107 & 97 & 90 & 104 & 86 & 153 & 69 & 98 & 103 & 134 & 122 & 129 \\
\hline Snow, mm & - & - & 8 & 96 & 324 & 1021 & 436 & 285 & 66 & - & - & - \\
\hline Avg. Temp, ${ }^{\circ} \mathrm{C}$ & 20.1 & 16.3 & 10.2 & 4.9 & -0.6 & -2.7 & -1.2 & 3.3 & 9.1 & 14.0 & 18.7 & 20.7 \\
\hline \multicolumn{13}{|l|}{ Yr 1 departure } \\
\hline Rain, mm & -14 & -19 & 43 & -71 & 12 & -72 & -69 & -37 & -49 & -4 & 54 & -66 \\
\hline Snow, mm & - & - & -8 & -58 & 324 & 122 & 2155 & -196 & -66 & - & - & - \\
\hline Avg. Temp, ${ }^{\circ} \mathrm{C}$ & 0.5 & 0.3 & -1.4 & 2.7 & -1.6 & -2.4 & -4.3 & 0.8 & 1.5 & 1.9 & 2.1 & 1.1 \\
\hline \multicolumn{13}{|l|}{ Yr 2 departure } \\
\hline Rain, mm & -30 & -2 & 3 & 9 & -42 & -144 & 4 & 43 & 125 & -51 & -21 & 32 \\
\hline Snow, mm & - & - & -8 & -96 & 508 & -94 & -258 & -221 & -28 & - & - & - \\
\hline Avg. Temp, ${ }^{\circ} \mathrm{C}$ & 1.1 & 1.3 & 0.1 & 0.3 & -5.7 & -2.9 & 0.9 & 0.3 & 1.9 & 2.3 & 0.8 & 1.9 \\
\hline \multicolumn{13}{|l|}{ Yr 3 departure } \\
\hline Rain, mm & 37 & 123 & 64 & 26 & 82 & -68 & 18 & 19 & -82 & 3 & -34 & -37 \\
\hline Snow, mm & - & - & -8 & -96 & -286 & -805 & -406 & -285 & -66 & - & - & - \\
\hline Avg. Temp, ${ }^{\circ} \mathrm{C}$ & 0.6 & 0.8 & -0.1 & 2.0 & 2.7 & 1.6 & 1.8 & 5.7 & -1.0 & 3.5 & 0.2 & 2.5 \\
\hline
\end{tabular}


Table 5. Nutritional composition of pastures during the fall grazing period.

\begin{tabular}{|c|c|c|c|c|c|c|c|c|c|c|}
\hline \multirow[b]{2}{*}{ Item, $\%$ of DM } & \multicolumn{2}{|c|}{ Year 1} & \multicolumn{2}{|c|}{ Year 2} & \multicolumn{2}{|c|}{ Year 3} & \multirow[b]{2}{*}{ SEM } & \multicolumn{3}{|c|}{$P$ - Value } \\
\hline & $\mathrm{LO}^{1}$ & $\mathrm{HI}^{2}$ & $\mathrm{LO}^{1}$ & $\mathrm{HI}^{2}$ & $\mathrm{LO}^{1}$ & $\mathrm{HI}^{2}$ & & Year & Treatment & $\begin{array}{c}\text { Year } x \\
\text { Treatment }\end{array}$ \\
\hline $\mathrm{CP}, \%$ & 15.9 & 15.6 & 19.7 & 19.1 & 17.1 & 17.0 & 0.83 & 0.05 & 0.38 & 0.59 \\
\hline $\mathrm{NDF}^{3}, \%$ & 52.8 & 52.7 & 49.9 & 48.4 & 51.8 & 51.0 & 0.31 & $<0.001$ & 0.06 & 0.40 \\
\hline IVTDMD $48^{4}, \%$ & 77.1 & 77.8 & 80.5 & 79.4 & 77.5 & 78.3 & 0.83 & 0.16 & 0.70 & 0.18 \\
\hline $\mathrm{TDN}^{5}, \%$ & 65.3 & 64.7 & 69.9 & 70.1 & 65.2 & 66.6 & 0.45 & $<0.001$ & 0.48 & 0.30 \\
\hline
\end{tabular}

${ }^{1} \mathrm{LO}=$ daily pasture $\mathrm{DM}$ allowance of $3.5 \%$ of $\mathrm{BW}$

${ }^{2} \mathrm{HI}=$ daily pasture DM allowance of $7.0 \%$ of BW

${ }^{3} \mathrm{NDF}=$ neutral detergent fiber

${ }^{4}$ IVTDMD48 = in vitro true dry matter digestibility

${ }^{5} \mathrm{TDN}=$ total digestible nutrients 
Figure 1. Mean herbage mass ( $\mathrm{kg} / \mathrm{ha})$ throughout the fall grazing periods for yr 1-3.

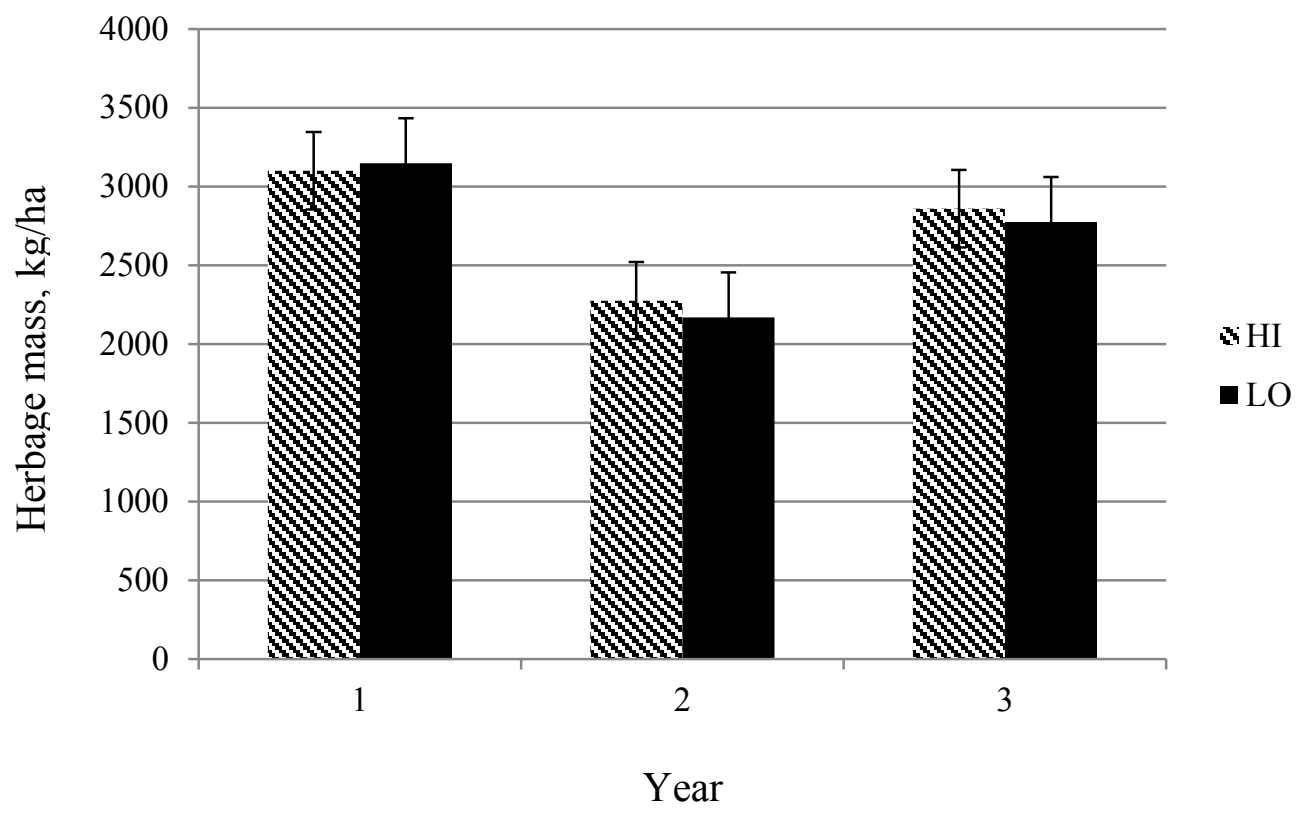

Year $\mathrm{x}$ treatment: $P=0.01$; SEM 79.3 
Figure 2. Herbage mass $(\mathrm{kg} / \mathrm{ha})$ decline during the fall grazing period for HI and LO treatments and for yr $1-3$.

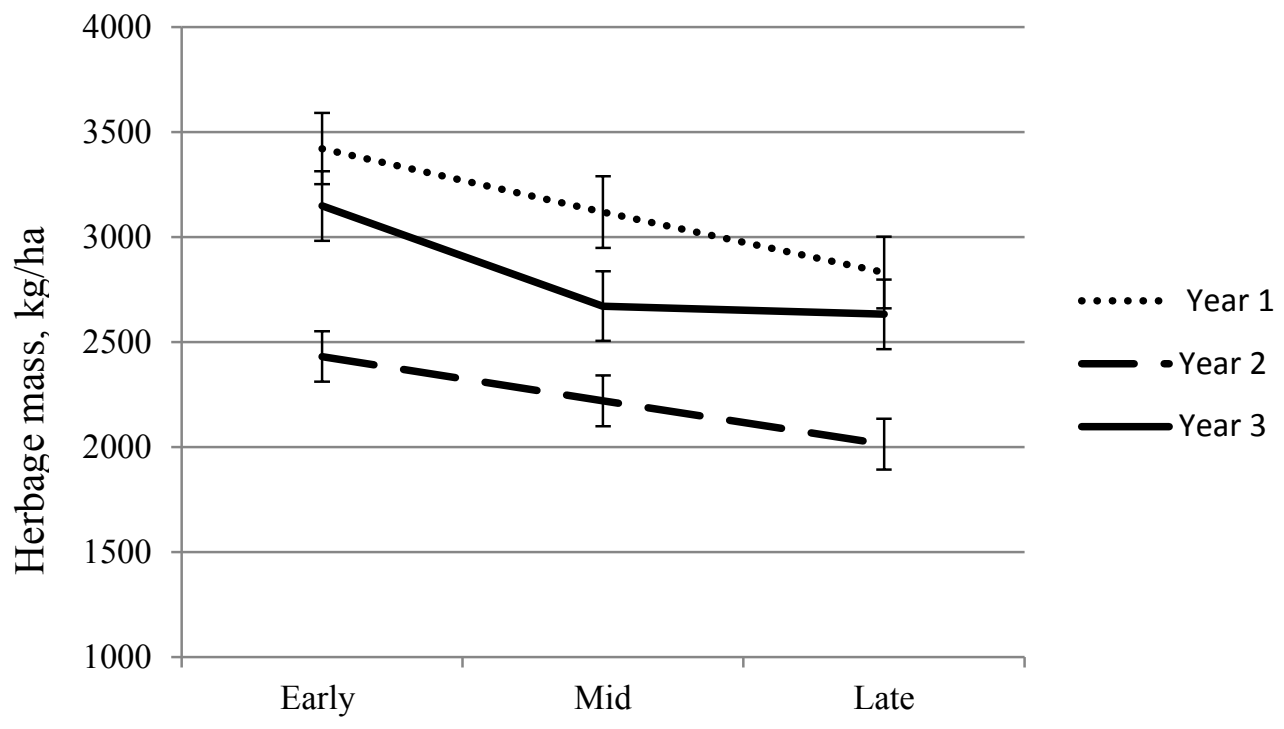

Year $\mathrm{x}$ sampling period: $P=0.02 ; \mathrm{SEM} 86.6$ 
Figure 3. Decline in crude protein (CP) throughout the fall grazing period.

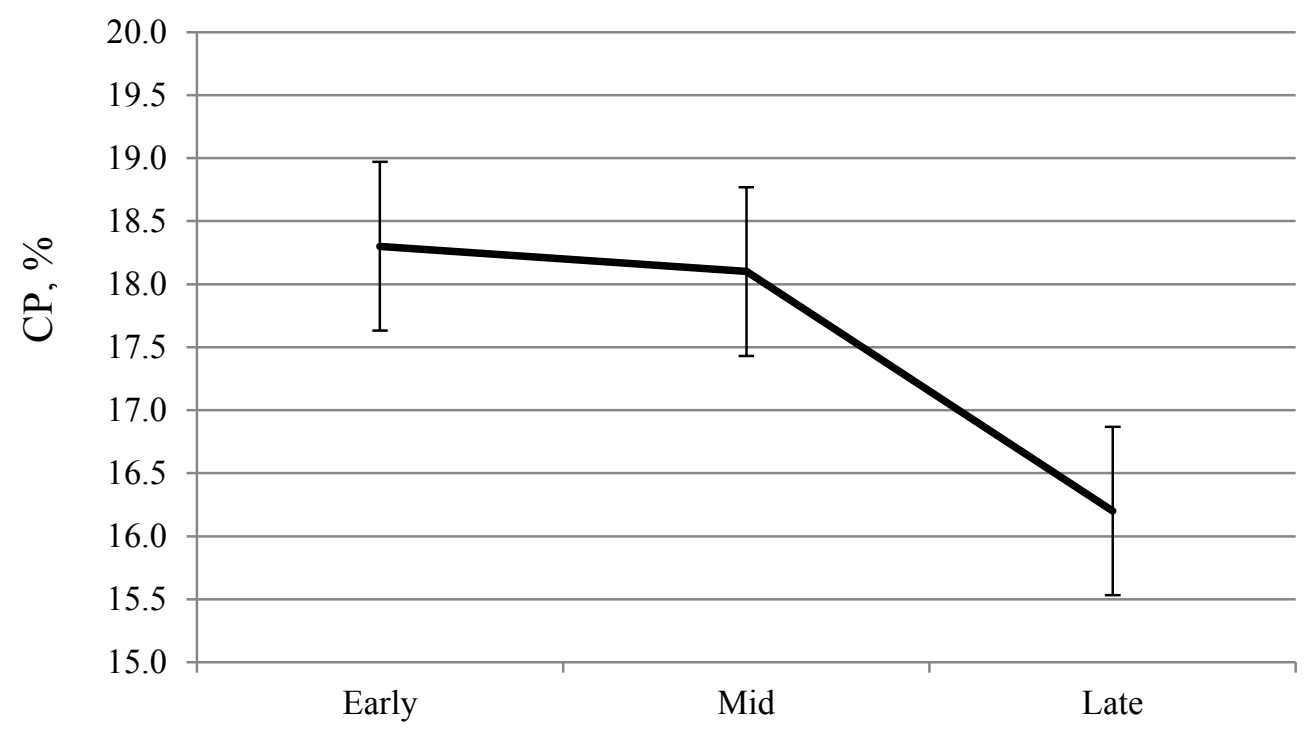

Sampling period effect: $P=0.003$; SEM 0.6 
Figure 4. Increase in neutral detergent fiber (NDF) throughout the fall grazing period.

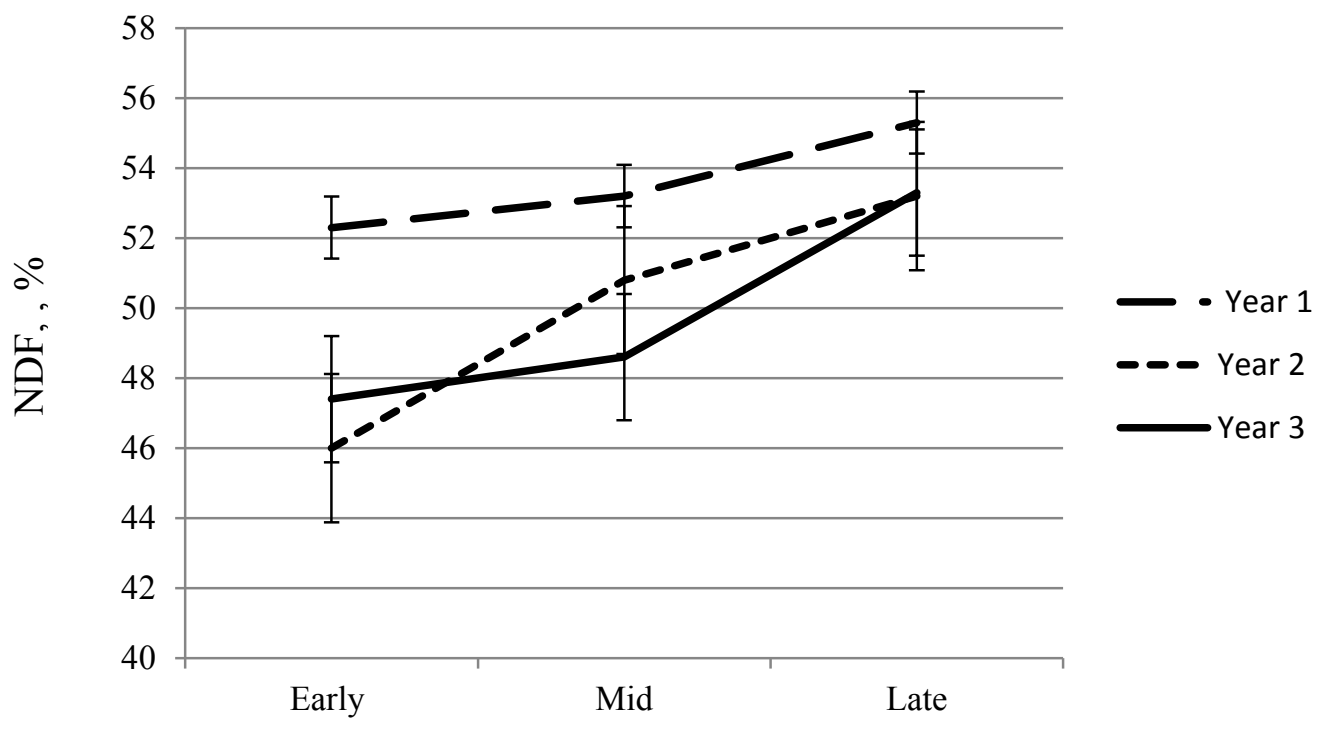

Year x sampling period: $P=0.0016$; SEM 1.1 
Figure 5. Decline in in vitro true dry matter digestibility (IVTDMD) throughout the fall grazing period.

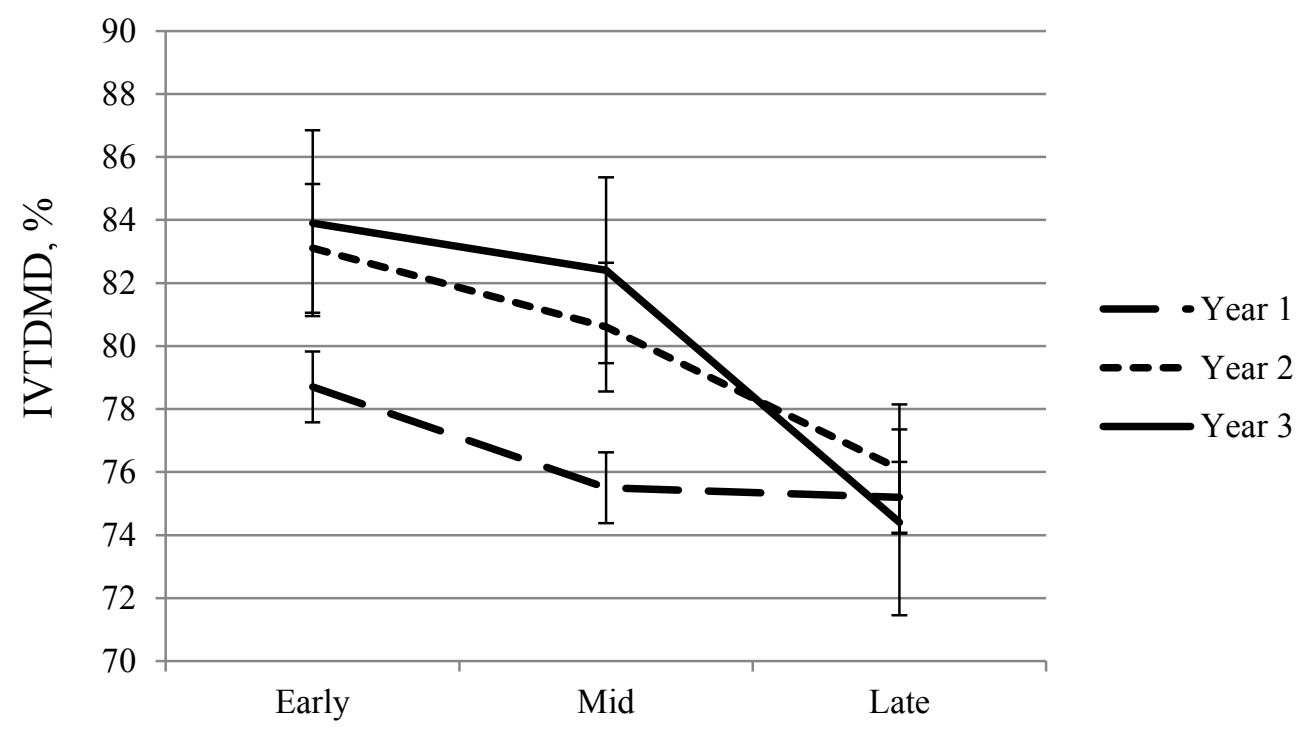

Year x Sampling Period: $P=0.009$; SEM 1.4 


\section{CHAPTER 3}

Beef heifer growth and reproductive performance responses to two levels of stockpiled fall forage allocation

${ }^{1}$ Formatted for submission to the Journal of Animal Science 


\title{
Beef heifer growth and reproductive performance following two patterns of gain during the fall grazing period
}

\author{
B.L. Bailey*, T.C. Griggs†, E. B. Rayburnł and K. M. Krause ${ }^{* 1}$
}

Division of Animal and Nutritional Sciences*, West Virginia University, Morgantown 26506;

Division of Plant and Soil Sciences $\uparrow$, West Virginia University, Morgantown 26506; and West Virginia University Extension Service:, Morgantown 26506

ABSTRACT: The objective of this study was to compare heifer growth and reproductive performance following two levels of stockpiled fall forage allowance. Spring born heifers $(\mathrm{n}=$ 203 , BW $=246 \pm 28.9 \mathrm{~kg}$ ) of primarily Angus background were allocated to two grazing treatments during the fall period each replicated 3 times per year for 3 years. Treatments consisted of daily herbage DM allocation of 3.5 (LO) or 7.0 (HI) \% of BW under strip-grazing management. Throughout the winter feeding period mixed grass-legume haylage and soybean hulls were fed. Heifers were grazed under continuous stocking (as one group) after the winter period. Heifers in the LO group gained $0.12 \mathrm{~kg} / \mathrm{d}$ whereas heifers in the HI group gained 0.40 $\mathrm{kg} / \mathrm{d}$ during the fall grazing period $(P<0.0001)$. Fall ADG was affected by NDF content of the pasture; for each 1 percentage unit increase in NDF, fall ADG decreased $0.14 \mathrm{~kg}(P<0.05)$. During winter feeding, ADG was $0.30 \mathrm{~kg} / \mathrm{d}$ and $0.39 \mathrm{~kg} / \mathrm{d}$ for LO vs HI heifers, respectively $(P<$ 0.001). During the spring grazing period, LO heifers had numerically higher ADG than $\mathrm{HI}$ heifers ( 1.38 vs. $1.30 \mathrm{~kg} / \mathrm{d} ; P=0.64)$. Hip height (122.7 vs. $121.4 \mathrm{~cm} ; P<0.01)$, BCS (5.8 vs 5.6; $P<0.01$ ), and BW (356 vs. $335 \mathrm{~kg} ; P<0.0001$ ) at the end of spring grazing was higher for HI heifers than LO heifers. Heifers in the LO group compensated with greater summer ADG than heifers in the HI group $(0.74$ vs. $0.66 \mathrm{~kg} / \mathrm{d} ; P<0.05)$. Total ADG from treatment initiation (November) through pregnancy diagnosis (August) was higher for HI heifers than LO heifers (0.61 vs. $0.55 \mathrm{~kg} / \mathrm{d} ; P<0.001)$ as was BW at pregnancy diagnosis $(415$ vs. $402 \mathrm{~kg} ; P<0.01)$. Percentage of heifers reaching puberty by the time of AI was $34 \%$ for both groups $(P=0.93)$. 
Percentage of heifers becoming pregnant to AI tended $(P=0.13)$ to be higher for $\mathrm{HI}$ heifers (44\%) than for LO heifers (32\%). Fall ADG across treatment groups affected the probability of a heifer becoming pregnant by AI $(P<0.05)$. Percentage pregnant to the bull $(61 \%$ for LO vs. $59 \%$ for $\mathrm{HI} ; P=0.80)$ and final pregnancy rate $(74 \%$ for $\mathrm{LO}$ vs. $77 \%$ for $\mathrm{HI} ; P=0.61)$ was similar for the two groups. We interpret these results to indicate that delaying the majority of weight gain until late in heifer development may decrease costs of winter feeding and has the potential to result in adequate overall pregnancy rates.

Key Words: beef heifers, grazing, reproductive performance

\footnotetext{
${ }^{1}$ Corresponding author: marie.krause@mail.wvu.edu
} 


\section{INTRODUCTION}

Forage systems in Appalachia are based on cool-season grasses such as orchardgrass (Dactylis glomerata), tall fescue (Schedonorus phoenix), white clover (T. repens), and red clover (Trifolium pretense). These systems have an abundance of forage in the spring and most falls, but are not as productive in mid to late summer. Feed resources used in developing replacement females are a major factor influencing cost of production (Freetly et al., 2001; Clark et al., 2005). Due to rising costs of production, interest is increasing in alternative heifer development systems utilizing grazing and minimizing the use of harvested feedstuffs (Larson et al., 2011). Several decades ago, guidelines were established indicating replacement heifers should achieve 60 to $65 \%$ of their expected mature body weight by breeding (Patterson et al., 1992). However, subsequent research has demonstrated that harvested feed input can be reduced without major adverse effects on reproduction. Recent research indicates heifers reaching $<55 \%$ of mature BW by breeding have similar reproductive ability to heavier counterparts (Funston and Deutscher, 2004; Martin et al., 2008). However, much of this research has been performed in a dry-lot setting and limited or no data exist comparing development systems utilizing standing forage (Larson et al., 2011). Additionally, there are limited data comparing the effects of different levels of stockpiled fall forage allocation of naturalized cool-season forage mixtures on beef heifer growth. Therefore, this study evaluated the effect of allocating two different levels (HI vs LO) of stockpiled cool-season naturalized pasture during the fall period on beef heifer growth, puberty, and pregnancy rate. 


\section{MATERIALS AND METHODS}

All procedures and facilities used in this study were approved by the West Virginia University Animal Care and Use Committee (IACUC \#09-0818).

\section{Experimental Procedures}

A 3-yr study (August 2009 through August 2012) was conducted with 203 beef heifers at the WVU Agricultural and Forestry Experiment Station Reedsville Farm in Reedsville, Preston County in northern WV (530 m elevation; 39 $\left.30^{\prime} \mathrm{N}, 79^{\circ} 50^{\prime} \mathrm{W}\right)$ to investigate heifer responses to two levels of fall forage allocation. For simplicity, the 2009-2010 season will be termed yr 1, the 2010-2011 season yr 2, and the 2011-2012 season yr 3. Heifers consisted of British breed types, being predominately Angus and Angus-cross females. After weaning, heifers were comingled at the West Virginia University Reedsville Farm (Reedsville, WV) and maintained on mixed cool-season grass pasture. Heifers were blocked by weight and randomly assigned to treatments. Treatments consisted of daily herbage dry matter (DM) allowances of 3.5\% (LO) or $7.0 \%(\mathrm{HI})$ of body weight $(\mathrm{BW})$ that were based on assigned land area during the fall grazing period. Herbage mass allowances were set below $6 \%$ (DM basis) of $\mathrm{BW}$ to restrict intake and above $6 \%$ of BW to avoid restriction of intake (Combellas and Hodgson, 1979). Three 5-ha fields were selected as blocks in a randomized complete block design for application of grazing treatments. Each pasture treatment replicate was considered to be an experimental unit $(n=6)$. Heifers were allocated to two grazing treatments $(n=10-12 /$ treatment replicate $)$, each replicated three times for the fall grazing period. All experimental units had been in long-term hay and pasture production and contained perennial cool-season species. The soil types at this location were silt loams with Rayne, Ernest, and Gilpin being most prevalent. Soil test results from 
sampling to a 5-8 $\mathrm{cm}$ depth over the 3 year experimental period were $\mathrm{pH}$ of $6.2,25 \mathrm{ppm} \mathrm{P}$, and 189 ppm K.

Stockpiling of pastures began in mid-late August of each year. Urea $(46 \% \mathrm{~N})$ was applied in August at $80-100 \mathrm{~kg} \mathrm{~N} / \mathrm{ha}$. Pastures were allowed to regrow without utilization for the remainder of the growing season, which ended in late October to early November. Fall grazing treatments began in early November and continued until snow conditions prevented grazing or pastures had been fully consumed. Herbage allowances were assigned by delineating appropriate paddock areas with portable electric fencing. Each treatment group was given a new paddock area every 3-5 days in a strip-grazing pattern without back fencing, allowing animals to return to a permanent watering point. Heifers on both treatments were given free-choice access to trace-mineralized salt (Morton ioFIXT T-M; Morton salt Inc., Chicago IL) containing 93 98\% salt, 3500 ppm zinc, 2800 ppm Manganese, 1750 ppm iron, 350 - 450 ppm copper, 70 ppm iodine and $70 \mathrm{ppm}$ cobalt. At the end of the fall grazing period, the winter feeding period began and round bale mixed-grass/legume haylage was fed on pastures $(5.9 \mathrm{~kg} \mathrm{DM} / \mathrm{hd} / \mathrm{d}, \mathrm{yr} 1 ; 5.4 \mathrm{~kg}$ $\mathrm{DM} / \mathrm{hd} / \mathrm{d}$, yr 2; $5.6 \mathrm{~kg} \mathrm{DM} / \mathrm{hd} / \mathrm{d}$, yr 3). During this same period, soybean hulls were also fed (1.7 $\mathrm{kg} \mathrm{DM} / \mathrm{hd} / \mathrm{d}$, yr 1; $1.5 \mathrm{~kg} \mathrm{DM} / \mathrm{hd} / \mathrm{d}$, yr 2; $1.8 \mathrm{~kg} / \mathrm{DM} / \mathrm{hd} / \mathrm{d}$, yr 3). Soybean hulls were chosen in order to comply with a forage based system. In early to mid-April haylage and soybean hull feeding ended and fences between herbage allowance treatments were removed and pastures were continuously stocked through late May (spring grazing period). Heifers from all 3 blocks were then combined into one group that rotated among pastures until early August (summer grazing period). 


\section{Forage Mass Determinations}

Forage mass of each experimental unit was determined at the end of each growing season (October 26, 2009, October 29, 2010 and October 21, 2011) and every 11-19 days thereafter, depending on environmental conditions, during the fall, spring and summer period except during the summer of yr 1 when no data were collected. Forage mass was determined from each experimental unit by taking at least 100 rising plate meter readings. An Ellinbank- type rising plate meter with $0.32 \times 0.32$ meter square aluminum plate was used (Earle and McGowan, 1979). It was obtained from the University of Missouri Research Reactor Center (MURR) 1513 Research Park Drive Columbia, MO 65211-3400. The rising plate meter readings were calibrated by clipping forage within square quadrats $\left(0.1 \mathrm{~m}^{2}\right)$ to nearly soil surface (approximately $1 \mathrm{~cm}$ ) using forged grass shears. The clipped samples were dried at $60^{\circ} \mathrm{C}$ for $\geq 48$ hours and weighed. Regression was used to develop herbage mass equations relating the clipped forage samples with the rising plate meter readings. For each period and year, a final herbage mass prediction model was selected following analysis of the following alternatives: 1) Simple linear regression with y-intercept; 2) simple linear regression with forced intercept through origin; 3) quadratic regression with y-intercept; and 4) quadratic regression with forced intercept through origin. Final regression equations shown in Table 1 were selected on the basis of levels of significance of y-intercept, coefficient of determination, and root MSE.

\section{Botanical Composition of Pastures}

Botanical composition of pastures was determined in late October each year using the dry-weight-rank method (Mannetje and Haydock, 1963). Measurements were obtained within a

$0.1 \mathrm{~m}^{2}$ quadrat and 55 data points were assessed for each experimental unit. 


\section{Forage Nutritive Composition}

To determine the nutritive value of the pastures, forage samples were taken every two weeks during the fall, spring and summer periods. Samples were also taken of the haylage and soybean hulls throughout the winter feeding period. Forage samples were analyzed in duplicate. Partial DM was determined by oven drying at $60^{\circ} \mathrm{C}$ for $48 \mathrm{~h}$. Dried samples were ground through a 1-mm screen in a Wiley mill (Arthur H. Thomas, Philadelphia, PA). Analytical lab $\mathrm{DM}$ of the forages was determined by oven drying at $100^{\circ} \mathrm{C}$ for $24 \mathrm{~h}$ (AOAC, 1995). Ash content was determined by combustion at $550^{\circ} \mathrm{C}$ overnight, using the procedure described by AOAC (1995). Neutral detergent fiber (NDF) and acid detergent fiber (ADF) content were determined using an Ankom 200 Fiber Analyzer (Ankom Technology Corp, Macedon, NY). Heat-stable $\alpha$ amylase and sodium sulphite treatments (Mertens, 2002) were used to obtain NDF. Ether extraction of the forages and soybean hulls was performed according to AOAC (1995) using a Soxtec Foss Tecator (Foss Analytical, Hillerd, Denmark). Crude protein (CP) content was analyzed according to AOAC (1995) using an automated Tecator digestion system (Tecator Inc., Herndon, VA).

In-vitro true dry matter digestibility (IVTDMD48) of haylage samples was determined by Cumberland Valley Analytical Services (14515 Industry Drive, Hagerstown, MD 21742) using the procedures of Goering and Van Soest (1970). Near-infrared reflectance spectroscopy (NIRS) was used to determine IVTDMD of pasture samples. Pasture samples for analysis of nutritive value via near-infrared reflectance spectroscopy (NIRS) were oven-dried for $48 \mathrm{~h}$ at $60^{\circ} \mathrm{C}$ and ground to pass a 1-mm screen of a cutting mill (Wiley Laboratory Mill, Mod. 4, Thomas Scientific, Swedesboro, NJ 08085). Each ground sample was riffle-split into subsamples that were a) retained without additional grinding; and b) reground to pass a 1-mm screen of a cyclone 
mill (Cyclotec 1093 Sample Mill, FOSS North America, Eden Prairie, MN 55344). Cycloneground subsamples packed in powder cells were used for collection of NIR spectra on a SpectraStar 2400 RTW scanning monochromator (Unity Scientific, Brookfield, CT 06804). Spectral data were recorded as the reciprocal $\log$ of reflectance $(\log 1 / \mathrm{R})$ at 1 -nm increments over a range of $1250-2350 \mathrm{~nm}$.

Chemometrics software (Ucal, ver. 2.0.0.31 for Windows, Unity Scientific, Brookfield, CT 06804) was used to select a calibration subset of 98-121 (depending on constituent) samples representing the distribution of spectral and chemical properties of the whole sample population, following procedures of Shenk and Westerhaus (1991). The same software was used to develop prediction equations relating reference wet chemical compositional values to NIR spectra in the calibration set, as described later.

Calibration subsamples that had been ground only through a 1-mm screen of a shear mill were analyzed by the University of Wisconsin Soil and Forage Analysis Laboratory, Marshfield, WI according to reference wet chemical procedures as follow: amylase-treated neutral detergent fiber (aNDF) as described in AOAC International (2010) methods 984.13 and 2002.04 (and Mertens, 2002), respectively, and in vitro true dry matter digestibility (IVTDMD) by incubating samples in buffered rumen fluid for $48 \mathrm{~h}$ followed by refluxing of indigestible residues in neutral detergent solution (Goering and Van Soest, 1970; Peters, 2013). For 48-h incubation times, values of IVTDMD are approximately 12 percentage units higher (Van Soest, 1994) than those of in vitro apparent digestibility for the same samples analyzed by the traditional two-stage procedure of Tilley and Terry (1963). Digestible NDF (dNDF, as a proportion of DM) and NDF digestibility (NDFD, as a proportion of NDF) were calculated from NDF and IVTDMD concentrations. 
Prediction equations relating reference wet chemical analytical values to NIR spectra were developed with modified partial least squares regression. Spectral data were first transformed to the first derivative of raw $(\log 1 / \mathrm{R})$ data; calculations were over every eight (1$\mathrm{nm})$ data points with a running smooth of eight (1-nm) data points. Statistical processing during equation development included two outlier elimination passes, five cross-validation groups, and use of standard normal variate with detrending for reduction of spectral variation due to light scattering caused by differences in particle size distribution and orientation among samples.

Standard errors of cross-validation for NIRS prediction equations were 37 (3.72\%), 36 (3.57\%), 37 (3.72\%), and $60(6.03 \%) \mathrm{g} / \mathrm{kg}$ for NDF, IVTDMD, dNDF, and NDFD, respectively. Proportions of variation in NDF, IVTDMD, dNDF, and NDFD concentrations in calibration samples accounted for by NIRS predicted values were $0.81,0.87,0.55$, and 0.79 , respectively. The total digestible nutrient (TDN) content of the pasture and haylage samples was calculated using the NRC (2001) summative equation.

\section{Animal Measurements}

Data were collected from approximately November 2 to August 20 in each of $3 \mathrm{yr}$ (2009 to 2012 ) on 203 spring-born weanling beef heifers ( $\mathrm{n}=72,64$, and 67 in yr 1-3, respectively). Mean BW, age, BCS and hip height at treatment initiation are presented in Table 2. Heifers were evaluated for growth (measured as weight gain, hip height, and body condition score). Individual BW was recorded upon treatment initiation and at 2-week intervals for the remainder of the trial period (261 days in yr 1; 272 days in yr 2; 274 days in yr 3). Hip height measurements were collected and body condition scores (BCS; scale 1 to $9 ; 1=$ extremely thin, 9 = obese; Wagner et al., 1988) were assigned to each animal at trial initiation and at approximately 28-d intervals through May by the same evaluator. Mature BW of heifers was estimated according to equations described in Fox et al., (1988). 
Averaged over the $3 \mathrm{yr}$, stocking rate (heifers/ha) for the entire pasture area including unoccupied paddocks during the fall grazing period was 6.0 for the LO treatment and 3.2 for the HI treatment. Stocking density, $(\mathrm{kg} / \mathrm{ha})$ for only the paddock area being grazed at any point in time during the fall grazing period was 25,358 and 13,229 for LO and HI treatments, respectively. Heifers grazed an average of 54 days during the fall grazing period, 38 days during the spring grazing period, 75 days during the summer grazing period, and were fed haylage for 101 days and soy hulls for 70 days during the winter feeding period.

\section{Determination of Puberty}

Circulating concentration of progesterone was used as an indicator of pubertal status. Blood samples were obtained once per month up until 4 weeks prior to breeding when they were taken once per week. Samples were collected into 10-mL EDTA vacutainer tubes via jugular venipuncture and cooled immediately on ice. Samples were refrigerated overnight at $4^{\circ} \mathrm{C}$, after which plasma was harvested by centrifugation $\left(3,000 \times g\right.$ at $4{ }^{\circ} \mathrm{C}$ for $\left.20 \mathrm{~min}\right)$ and stored at $-80^{\circ} \mathrm{C}$. Plasma concentrations of progesterone for each heifer were determined in duplicate using direct solid-phase RIA (Coat-a-Count Progesterone, Siemens Medical Solutions Diagnostics, Dallas, TX) without extraction, as described by Melvin et al. (1999). Heifers with progesterone concentrations of $>1 \mathrm{ng} / \mathrm{ml}$ at the end of the developmental period were considered to be pubertal. Intra and interassay $\mathrm{CV}$ were $5.3 \%$ and $9.2 \%$, respectively for yr 1 ( $\mathrm{n}=8$ assays), $3.5 \%$ and $8.7 \%$, repectively for yr $2(\mathrm{n}=9$ assays), and $6.3 \%$ and $5.5 \%$, respectively for yr $3(\mathrm{n}=$ 10 assays). Sensitivity for minimum detection was $0.02 \mathrm{ng} / \mathrm{ml}$.

\section{Synchronization and Breeding Protocol}

In all years, heifers were synchronized in May by insertion of an intravaginal controlled internal drug-releasing device (Eazi-Breed CIDR, Pfizer Animal Health, New York, NY) for 7 days followed by a prostaglandin injection (Lutalyse, Pfizer Animal Health) at time of CIDR 
removal and a $2 \mathrm{~mL}$ estradiol injection 40 hours after CIDR removal. All heifers received timed AI approximately 72 hours after CIDR removal. A cleanup bull was used for 35 days. Pregnancy status was determined via rectal palpation in early August.

\section{Statistical Analysis}

Because treatment was fall pasture allowance and heifers were managed either on LO or HI and replicated $3 \mathrm{yr}$, LO fields $(n=3)$ and HI fields $(n=3)$ were considered the experimental units for heifer performance and reproductive data. Continuous data were analyzed with PROC MIXED (SAS Inst. Inc., Cary, NC). The statistical model included fall pasture allowance (treatment) as the fixed effect. Year, block within year, and treatment by block within year were included as random variables. ADG over periods (seasons) were analyzed as repeated measurements. The statistical model included fall pasture allowance (treatment), period (season), and treatment by period interaction as fixed effects and Kenward-Rogers adjustment for degrees of freedom was applied. The model with the best fit according to Akaike's Information Criterion used a heterogeneous autoregressive covariance structure. The relationships between fall ADG and nutritional composition of the pastures were investigated using PROC MIXED. The model included nutritional variables as a fixed effect and year and block within year as random effects. Binary variables were analyzed using PROC GLIMMIX utilizing the same model as for continuous variables. The relationship between fall ADG and pregnancy outcome by AI was analyzed using the GLIMMIX procedure and a logit-link function. Significant differences were defined as $P \leq 0.05$ and tendencies at $P \leq 0.15$. To determine regression equations for prediction of herbage mass the NCSS 2000 Statistical System was used (Hintze, 1998). 


\section{RESULTS AND DISCUSSION}

\section{Climatological Data}

Precipitation (rainfall and snowfall) and temperatures were recorded on site (Table 3). Average temperature for the 3 yr study was consistent with the $30 \mathrm{yr}(1980-2010)$ average for the area. In yr 1, rainfall was below average during the first part of the accumulation period in August and September followed by above average rainfall in October. During the winter, snow in December was $324 \mathrm{~mm}$ above average which mostly occurred in one snowfall event which ended fall grazing early. In January and February, snowfall amounts were above average, 122 and $2155 \mathrm{~mm}$, respectively. Rainfall during the spring and summer was generally below average. This trend continued into the fall forage accumulation period of yr 2 with rainfall amounts in July, August and September below average which contributed to lower herbage mass amounts at the end of the fall stockpiling period in year 2. During the winter of yr 2, snowfall amounts were below average in November, January and February. Rainfall was above average in March and April, below average in May and June and above average in July and August and continuing through the accumulation period of yr 3. These above average rainfall amounts contributed to more stockpiled forage in yr 3 than yr 1 and 2. However, throughout the majority of the fall grazing period (November and December) rainfall was still above average which resulted in some trampling and burial of pasture grasses and therefore intake may have been lower than expected.

\section{Botanical Composition}

Herbage mass averaged across all grazing events of the entire experiment (2009-2012) was composed of 59\% grass, $19 \%$ legumes, and 22\% non-legume forbs. Predominant species 
included orchardgrass $(30.5 \%)$, tall fescue $(14.1 \%)$, white clover $(9.9 \%)$, red clover $(9.5 \%)$, narrowleaf plantain (Plantago lanceolata; 9.0\%) and quackgrass (Elymus repens; 8.5\%).

\section{Herbage Mass}

During the fall grazing period, beginning herbage mass was $3,884 \mathrm{~kg} / \mathrm{ha}$ in yr 1,2,994 $\mathrm{kg} / \mathrm{ha}$ in $\mathrm{yr} 2$, and $3,872 \mathrm{~kg} / \mathrm{ha}$ in $\mathrm{yr} 3$. Beginning herbage mass in yr 2 was lower than in other years due to below average rainfall amounts in July, August, and September. This resulted in a shorter grazing period (58 d), compared to yr 3 (68d). Mean beginning herbage mass in yr 1 was similar to yr 3 (3,884 vs 3,872 kg/ha, respectively); however, above average snowfall in December yr 1 ended grazing early. This resulted in only $35 \mathrm{~d}$ grazing in the fall of yr 1 compared to $68 \mathrm{~d}$ grazing in yr 3. Cool-season grasses consistently produce the greatest percentage of their annual yield during the spring when reproductive growth occurs, soil moisture is adequate, and temperatures are near optimum (Denison and Perry, 1990; Moser and Hoveland, 1996). In this study, however, average herbage mass amounts during spring were lower than what would normally be expected because heifers had been in the pastures since November and therefore the pastures were never given a rest period. Mean herbage mass amounts throughout the fall, spring and summer periods is presented in Table 4.

\section{Forage Quality}

Nutritional composition of pastures, haylage and soybean hulls is described in Tables 5 and 6. Pastures were consistently higher in quality based on percentages of CP and NDF, than the haylage. This is expected because these forages are generally harvested at a later stage of maturity than forages that are grazed. During the fall grazing period, CP averaged $17.3 \%$ for LO and $17.1 \%$ for HI treatment groups, more than adequate for wintering beef heifers (NRC, 2000). Fall means for NDF, IVTDMD and TDN were $51.3 \%, 78.3 \%$, and $66.6 \%$, respectively. There 
was a larger difference between HI and LO treatments for NDF (50.9\% vs 51.7\%, respectively) than for IVTDMD (78.4\% vs 78.1\%) and TDN (66.8\% vs $66.5 \%)$.

\section{Heifer Performance: Growth}

Heifer BW, BW gain and growth data are displayed in Table 7. Heifers averaged $232 \pm$ 17.5 days of age and $246 \pm 28.9 \mathrm{~kg}$ at trial initiation across all years. Initial BW did not differ between treatments, $246 \mathrm{~kg}$ for LO and $245 \mathrm{~kg}$ for $\mathrm{HI}(P=0.93)$. There was a significant treatment $\mathrm{x}$ period interaction for heifer ADG $(P<0.001)$, which was to be expected given that the different pasture allowances were only applied to the fall season. Heifers on the HI treatment gained more weight $(0.40 \mathrm{~kg} / \mathrm{d})$ than did heifers on the LO treatment $(0.12 \mathrm{~kg} / \mathrm{d} ; 0.12 \mathrm{~kg} / \mathrm{d} ; P<$ 0.0001) during the fall grazing period. Poore et al. (2006) reported ADG for un-supplemented heifers strip-grazing stockpiled fescue from early December to late February of $0.35 \mathrm{~kg} / \mathrm{d}$ (yr 1) and $0.18 \mathrm{~kg} / \mathrm{d}$ (yr 2) with stocking rates of 5.9 and 7.8 heifers/ha, respectively. The stocking rates and ADG reported by Poore et al. (2006) are similar to those in this study. In contrast, a study by Drewnoski et al. (2009), reported that ADG of heifers strip-grazing stockpiled fescue from December through February was $0.60 \mathrm{~kg} / \mathrm{d}$ (average of $4 \mathrm{yr}$ ). In that study, heifers were moved every day and the strip size was adjusted based on residue from the previous day which could have contributed to higher ADG than seen in this study.

As mentioned previously, there was a larger difference between treatments for NDF than for IVTDMD and TDN. Because cell walls contribute to rumen fill, NDF concentration of herbage is a determinant of dietary intake (Jung and Allen, 1995). There was a significant relationship between fall ADG and NDF content of the pasture. For each 1 percentage unit increase in $\% \mathrm{NDF}$, fall ADG decreased by $0.14 \mathrm{~kg}(P=0.01)$. Therefore, the difference in fall ADG between treatments was not just caused by the difference in pasture allowance, but also by 
difference in NDF concentration. Although pasture intake is influenced primarily by DM allowance, $\%$ NDF of available pasture has relevance in grazing-based systems because it is negatively associated with potential intake (Vazquez and Smith, 2000). The general role of NDF in the diet of cows was described by Mertens (1997): if the forage consumed has excessive NDF, intake and productivity may be reduced. Thus, the amount of dietary fiber can have an impact on pasture utilization.

At the beginning of the winter feeding period, both $\mathrm{HI}$ and LO heifers lost weight for approximately the first 35 days (data not shown), which suggests that there may be an adjustment phase for feeding haylage. During the winter feeding period, ADG was $0.30 \mathrm{~kg} / \mathrm{d}$ and $0.39 \mathrm{~kg} / \mathrm{d}$ for LO vs HI heifers, respectively $(P=0.0008)$. Heifers in the LO treatment group gained 0.18 $\mathrm{kg} / \mathrm{d}$ more during the winter than in the fall grazing period and ADG for HI heifers in the winter remained basically the same as ADG during the fall. Hip height $(122.7 \mathrm{~cm}$ vs $121.4 \mathrm{~cm} ; P<$ $0.01)$ and BCS (5.8 vs 5.6; $P<0.01)$ at the end of spring grazing was higher for $\mathrm{HI}$ heifers than LO heifers, respectively. During the spring grazing period, LO heifers had numerically higher ADG than HI heifers (1.38 vs $1.30 \mathrm{~kg} / \mathrm{d} ; P=0.64)$. This difference in ADG persisted during the summer grazing period, where heifers on the LO treatment had higher ADG than heifers on the HI treatment $(0.74$ vs $0.66 \mathrm{~kg} / \mathrm{d} ; P<0.05)$. Heifers grazed an average of 38 days during the spring grazing period and 75 days during the summer grazing period. Differences in ADG for the spring grazing period may have been larger (as seen during the summer grazing period) had the period lasted longer than 38 days.

Heifer ADG from treatment initiation (November) through breeding (May) was higher for the HI treatment group than the low ( $0.56 \mathrm{vs} 0.46 \mathrm{~kg} / \mathrm{d} ; P<0.001)$. Total ADG from treatment initiation (November) through pregnancy diagnosis (August) was higher for HI heifers 
than LO heifers ( $0.61 \mathrm{vs} 0.55 \mathrm{~kg} / \mathrm{d} ; P<0.001)$. Allen et al. (2000) demonstrated that steers grazing an alfalfa-orchardgrass pasture from mid-November through mid-December, fed alfalfaorchardgrass hay until about April 8 to April 27, and then grazed bluegrass-white clover pasture through mid-October gained $0.49 \mathrm{~kg} / \mathrm{d}$ for the entire period (mid-November through midOctober). The ADG reported by Allen et al. (2000) is lower than the ADG in the current study and could be due to overstocking that occurred while steers were grazing the bluegrass-white clover pasture.

Although heifers on the LO treatment gained more during spring and summer, their BW at the end of the summer grazing period was lower than the BW of heifers on the HI treatment (402 vs $415 \mathrm{~kg} ; P<0.01$ ). However, this difference in BW between treatment groups at the time of pregnancy diagnosis had been reduced compared to the difference in BW at the end of the spring grazing period ( $335 \mathrm{~kg}$ for $\mathrm{LO}$ heifers vs $356 \mathrm{~kg}$ for $\mathrm{HI}$ heifers; $P<0.0001$ ). This indicates that the LO heifers were able to compensate during the breeding season for some of the difference created by the fall grazing treatment (Figure 1).

Heifers developed extensively, that is, under conditions of dormant or scarce forage, low precipitation, undulating terrain, and large pastures, or those that are restricted-gain pen developed often exhibit compensatory gain during the summer grazing period (Endecott et al., 2013). Studies have shown that range-developed heifers with minimal pre-breeding ADG compensate during the breeding season and gain more BW than feedlot-developed heifers due to decreased maintenance requirements and the ability to respond to a seasonal improvement in forage quality (Marston et al., 1995; Ciccioli et al., 2005). A study conducted in 2012 by Mulliniks and others demonstrated that heifers developed in a dry lot had higher ADG (0.69 $\mathrm{kg} / \mathrm{d}$ ) from initiation of the study to breeding compared to heifers developed on low-quality 
forage with protein supplementation, who only gained $0.26 \mathrm{~kg} / \mathrm{d}$. However, the range developed heifers compensated during the breeding season and had greater ADG $(0.83 \mathrm{~kg} / \mathrm{d})$ than dry lot heifers $(0.61 \mathrm{~kg} / \mathrm{d})$. Research conducted by Larson and Funston (2011) evaluated the effect of heifers grazing corn residue (CR) compared with winter range (WR). Heifers grazing CR tended to have lower ADG than WR heifers during the winter grazing and pre-breeding period ( 0.14 vs $0.24 \mathrm{~kg} / \mathrm{d} ; 0.29 \mathrm{vs} 0.38 \mathrm{~kg} / \mathrm{d}$ ), but had similar BW at breeding as WR heifers. Heifers grazing CR were approximately $52 \%$ of mature BW at breeding and WR heifers were $55 \%$. During the summer, heifers grazing CR tended to compensate with greater ADG $(0.73 \mathrm{~kg} / \mathrm{d})$ than WR heifers $(0.67 \mathrm{~kg} / \mathrm{d})$.

Outcomes from grazing systems are variable and will change depending upon site, climate, soils, forage species, kinds and classes of livestock and other influencing factors (Allen et al., 2000). Because grazing systems function as a whole and are the result of interactions among their components, it is difficult to make direct comparisons, especially with naturalized pastures. However, evaluating the relationships within system components and overall system results can allow for better educated decisions when designing systems to match livestock feed requirements to forage types.

\section{Heifer Performance: Reproduction}

Heifer reproductive data are presented in Table 8 . There was no effect of fall pasture allowance on percentage of heifers reaching puberty by the time of AI ( $34 \%$ for both groups; $P=$ 0.93). As mentioned earlier, heifers in the LO treatment group weighed less at breeding than heifers in the HI treatment group ( $335 \mathrm{vs} 356 \mathrm{~kg} ; P<0.01$ ) and were approximately $63 \%$ of mature BW, whereas those in the $\mathrm{HI}$ group were $66 \%$ of mature BW $(544 \mathrm{~kg})$ at breeding $(P=$ 0.14). The percentage of heifers becoming pregnant to AI tended $(P=0.13)$ to be higher $(44 \%)$ 
for the $\mathrm{HI}$ heifers than for the $\mathrm{LO}$ heifers $(32 \%)$. The percentage pregnant to the bull was similar ( $61 \%$ for LO vs $59 \%$ for HI; $P=0.80$ ) between the two groups. Final pregnancy rate was also not different ( $74 \%$ vs $77 \% ; P=0.61)$ among $\mathrm{LO}$ and $\mathrm{HI}$ heifers, respectively. It is possible the synchronization system utilized in this study potentially prevented decreased reproductive outcomes because CIDR's have been shown to induce puberty in non-cycling beef females (Lucy et al., 2001).

Research conducted by Funston and Larson (2011) compared traditional post-weaning dry lot (DL) development with a more extensive winter grazing system utilizing a combination of corn residue and winter range (EXT). During the winter grazing period, EXT heifers gained less BW than DL heifers and EXT heifers had lighter BW at breeding. Final pregnancy rates did not differ, however, AI pregnancy rate tended $(P=0.08)$ to be less for EXT heifers. Roberts et al., (2009) offered heifers ad libitum or restricted access to feed for a 140 day period after weaning. Restricted heifers had lower ADG ( $0.53 \mathrm{vs} 0.65 \mathrm{~kg} / \mathrm{d})$ than control heifers. Differences in heifer ADG and BW persisted through pre-breeding, but from the end of the $140 \mathrm{~d}$ restriction at about 12.5 to 19.5 mo of age, ADG was greater $(0.51 \mathrm{vs} 0.47 \mathrm{~kg} / \mathrm{d})$ in restricted heifers than control heifers. Pregnancy rate from AI tended to be less in restricted (48\%) than control heifers (57\%); however, overall pregnancy rates did not differ.

As stated previously, the percentage of heifers becoming pregnant to AI tended to be higher for the $\mathrm{HI}$ heifers ( $32 \%$ vs $44 \% ; P=0.13$ ). This trend towards an effect of fall pasture allowance on pregnancy by AI was supported by a significant relationship between fall ADG and AI pregnancy rate. Figure 2 represents the predicted probability of heifers becoming pregnant to AI based on fall ADG. As the ADG increases $1 \mathrm{~kg}$, the odds of a heifer becoming pregnant increase $(P<0.05)$. The probability of a heifer becoming pregnant by AI with ADG in the fall 
of $0 \mathrm{~kg}, 0.5 \mathrm{~kg}$, and $1.0 \mathrm{~kg}$ is $29 \%, 46 \%$, and $64 \%$, respectively. The large range in fall ADG across treatment groups $(-0.39$ to $1.34 \mathrm{~kg} / \mathrm{d})$ probably contributed to the significant relationship between fall ADG and AI pregnancy outcome.

In the aforementioned study by Roberts et al., (2009), it was demonstrated that the covariate of BW at the initiation of the feeding trial indicated a 0.17 increase in percent pregnancy rate from $\mathrm{AI}$ and 0.089 decrease in day of the breeding season that conception occurred for each additional kilogram of BW. These results indicated that BW at 7 to 8 mo of age may influence time of conception in the first breeding season. This supports the results from our study where ADG of heifers averaging 7 to 8 mo of age during the fall grazing period influenced the probability of pregnancy by timed AI. Roberts et al., (2009) further evaluated this concept by conducting another analysis of pregnancy measures using a model that included covariates of ADG from birth to weaning, ADG from weaning to beginning of the feeding treatment, and within treatment ADG during the 140-d trial. Results indicated a 3.9 and 3.4 increase in percentage pregnancy rate from AI with each $0.1 \mathrm{~kg} / \mathrm{d}$ increase in ADG from birth to weaning and from weaning to beginning of treatment, respectively. Pregnancy rate from AI was not influenced by within treatment ADG during the 140-d trial. Final pregnancy rate was not influenced by any of the covariates. It was concluded that rate of growth during the pre-weaning and early post-weaning phase have a greater effect on when heifers become pregnant than rate of growth during the latter part of the post-weaning period.

Our findings support and expand the studies previously discussed and suggest that overall reproductive performance is not affected adversely when virtually all of the post-weaning weight gain is achieved through compensatory gain during the summer breeding period; however, fall ADG may affect first service conception rates. The percentage of heifers becoming pregnant to 
AI tended to be higher for HI heifers than LO heifers $(P=0.13)$ while final pregnancy rates were similar for both LO and HI treatments (74\% vs $77 \% ; P=0.61$, respectively).

As discussed by Larson and Funston (2011), most of the current research on heifer development has been conducted in a traditional dry lot setting and limited to no data exist comparing development systems utilizing standing forage. Increasing costs of feeds have prompted producers to consider heifer development systems utilizing low-cost/low-input feedstuffs including extended-season grazing utilizing stockpiled forage. These data and previously published data indicate that delaying the majority of gain until 35-44 days prior to breeding has the potential to result in overall pregnancy rates; however, fall forage allowance and ADG must be adequate for acceptable first service conception rates. Also, producers can utilize stockpiled fall and winter forage as conditions allow. Moreover, heifers developed in this manner still reached $63 \%$ to $66 \%$ of mature BW by breeding.

Additionally, this system did not require dry-lot or barn feeding; therefore, nutrients were recycled directly back to the soil to support forage growth. Also, it is important to note that heifers were only supplemented with the equivalent of $0.24 \mathrm{~kg}$ of protein/d during the winter period (approximately $73 \mathrm{~d}$ ) and gained between 0.30 and $0.39 \mathrm{~kg} / \mathrm{d}$ during the winter period. However, once placed on high quality spring pasture, heifers gained 1.31 to $1.39 \mathrm{~kg} / \mathrm{d}$ prebreeding and 0.67 to $0.74 \mathrm{~kg} / \mathrm{d}$ during and after the breeding season. Regardless of these compensatory BW gains, LO heifers weighed $6 \%$ less before breeding than HI heifers, had achieved approximately $63 \%$ of mature BW and had similar pregnancy rates at the end of the breeding season. The large range in age at breeding across treatment groups ( $373 \mathrm{~d}$ to $465 \mathrm{~d})$ may have contributed to less than satisfactory AI and final pregnancy rates for both LO and HI treatment groups. 
These findings suggest that delaying selection of replacement heifers until pregnancy evaluation may be a potential management strategy that would provide producers the opportunity to select heifers capable of achieving acceptable reproductive performance under restricted conditions. Also, heifers developed on pasture based systems that do not become pregnant and are therefore not kept as replacements could be sold as "Pasture Raised Beef" providing producers the opportunity to take advantage of potential niche markets, premium prices and higher profits. The goal of heifer development programs should not be to produce heifers with the greatest BW gain, but instead to produce a functional, pregnant heifer utilizing low-cost methods. Even though it may be impractical to remove hay from the winter feed system, utilizing stockpiled forages to increase the number of days that grazing can replace stored feed as the source of nutrients has the potential to significantly reduce costs of production while still achieving acceptable heifer performance. 


\section{REFERENCES}

Allen, V. G., Fontenot, J. P., and Brock, R. A. 2000. Forage systems for production of stocker steers in the upper south. J. Anim. Sci. 78:1973-1982.

AOAC International. 2010. Official methods of analysis of AOAC International. W. Horwitz and G.W. Latimer Jr., ed. $18^{\text {th }}$ ed. Rev. 3. AOAC International. Gaithersburg, MD.

Association of Official Analytical Chemists. 1995. Official Methods of Analysis. Vol I. 16th ed. AOAC, Arlington, VA.

Barnes, R.F, D.A. Miller, and C.J. Nelson. 1995. Forages. Volume 1. An introduction to grassland agriculture. Iowa State Univ. Press, Ames.

Blaser, R.E. and Colleagues. 1986. Forage Animal Management Systems. Va. Agr. Exp. Sta. Bull, 86-7. VPI and SU. Blacksburg VA 24061 90pp.

Brummer, E.C. and K. J. Moore. Persistence of Perennial Cool-Season Grass and Legume Cultivars under Continuous Grazing by Beef Cattle. 2000. Agron. J. 92:466-471 (2000).

Ciccioli, N.H., S.L. Charles-Edwards, C. Floyd, R.P. Wettemann, H.T. Purvis, K.S. Lusby, G.W. Horn, and D.L. Lalman. 2005. Incidence of puberty in beef heifers fed high- or lowstarch diets for different periods before breeding. J. Anim. Sci. 83:2653-2662.

Clanton, D.C., L.E. Jones, and M.E. England. 1983. Effect of rate and time of gain after weaning on the development of replacement beef heifers. J. Anim. Sci. 56:280-285.

Clark, R. T., K. W. Creighton, H. H. Patterson, and T. N. Barrett. 2005. Symposium paper:

Economic and tax implications for managing beef replacement heifers. Prof. Anim. Sci. 21:164173.

Combellas, J., and J. Hodgson. 1979. Herbage intake and milk production by grazing dairy cows. 1: The effect of variations in herbage mass and daily herbage allowance in a short term trial. Grass Forage Sci. 34:209-214.

Denison, R. F., and Perry, H. D. 1990. Seasonal growth rate patterns for orchardgrass and tall fescue on the Appalachian plateau. Agron. J. 82:869-873.

Drewnoski M.E., E. J. Oliphant, B. T. Marshall, M. H. Poore, J. T. Green and M. E. Hockett. 2009. Performance of growing cattle grazing stockpiled Jesup tall fescue with varying endophyte status. J. Anim. Sci., 87:1034-1041.

Earle, D.F. and A. A. McGowan. 1979. Evaluation and calibration of an automated rising plate meter for estimating dry matter yield of pasture. Aust. J. Exp. Agric. Anim. Husb. 19: $337-343$.

Endecott, R.L., R. N. Funston, J. T. Mulliniks and A. J. Roberts. 2013. Joint Alpharma-Beef 
Species Symposium: Implications of beef heifer development systems and lifetime productivity J. Anim Sci 91:1329-1335.

Freetly, H.C., C.L. Ferrell, and T.G. Jenkins. 2001. Production performance of beef cows raised on three different nutritionally controlled heifer development programs. J. Anim. Sci. 79:819-826.

Funston, R.N., and G.H. Deutscher. 2004. Comparison of target breeding weight and breeding date for replacement beef heifers and effects on subsequent reproduction and calf performance. J. Anim. Sci. 82:3094-3099.

Funston, R. N. and D. M. Larson. 2011. Heifer development systems: Dry-lot feeding compared with grazing dormant winter forage. J. Anim. Sci. 89:1595-1602.

Goering, H.K., and Van Soest, P.J. 1970. Forage fiber analyses. Agric. Handbook No. 379. USDA-ARS, Washington, DC.

Hintze, J. L. 1998. NCSS 2000 Statistical System. Number Cruncher Statistical Systems, Kaysville, UT. 84037.

Jung, H.G., and M.S. Allen. 1995. Characteristics of plant cell walls affecting intake and digestibility of forages by ruminants. J. Anim. Sci. 73:2774-2790.

Larson, D. M., A. S. Cupp, and R. N. Funston. 2011. Heifer development systems: A comparison of grazing winter range or corn residue. J. Anim. Sci. 89:2365:2372.

Lucy M.C., H.J. Billings, W.R. Butler, L.R. Ehnis, M.J. Fields, D.J. Kesler, J.E. Kinder, R.C. Mattos, R.E. Short, W.W. Thatcher, R.P. Wettemann, J.V. Yelich and H.D. Hafs. 2001. Efficacy of an intravaginal progesterone insert and an injection of PGF2alpha for synchronizing estrus and shortening the interval to pregnancy in postpartum beef cows, peripubertal beef heifers, and dairy heifers. J. Anim. Sci. 79:982-995.

Lynch, J.M., G.C. Lamb, B.L. Miller, R.T. Brandt, Jr., R.C. Cochran, and J.E. Minton. 1997. Influence of timing of gain on growth and reproductive performance of beef replacement heifers. J. Anim. Sci. 75:1715-1722.

Marston, T. T., K. S. Lusby, and R. P. Wettemann. 1995. Effects of postweaning diet on age and weight at puberty and milk production of heifers. J. Anim. Sci. 73:63-68.

Martin, J. L., K. W. Creighton, J. A. Musgrave, T. J. Klopfenstein, R. T. Clark, D. C. Adams, and R. N. Funston. 2008. Effect of prebreeding body weight or progestin exposure before breeding on beef heifer performance through the second breeding season. J. Anim. Sci. $86: 451-459$.

Mannetje, L.T., and K.P. Haydock. 1963. The dry-weight rank method for the botanical analysis of pasture. J. British Grassland Soc. 18:268-275. 
Mertens D.R. 2002. Gravimetric determination of amylase-treated neutral detergent fibre in feeds with refluxing beakers or crucibles: collaborative study. J. Assoc. Off. Assoc. Chem. Int., $85,1217-1240$.

Mertens, D.R. 1997. Creating a system for meeting the fiber requirements of dairy cows. J. Dairy Sci. 80:1463-1481.

Moser, L. E., and Hoveland, C. S. 1996. Cool-season grass overview. Pages 1-14 in: CoolSeason Forage Grasses. Agron. Monogr. 34. L. E. Moser, D. R. Buxton, M. D. Casler, eds. ASA, CSSA, SSSA, Madison, WI.

Mulliniks, J. T., D. E. Hawkins, K. K. Kane, S. H. Cox, L. A. Torell, E. J. Scholljegerdes, and M. K. Petersen. 2012. Metabolizable protein supply while grazing dormant winter forage during heifer development alters pregnancy and subsequent in-herd retention rate. J. Anim. Sci. 90:In Review.

National Research Council. 2000. Nutrient Requirements of Beef Cattle. 6th rev. ed. National Academy Press, Washington, DC.

National Research Council. 2001. Nutrient Requirements of Dairy Cattle. (7th Rev Ed.). Natl. Acad. Sci., Washington, DC.

Patterson, D.J., R.C. Perry, G.H. Kiracofe, R.A. Bellows, R.B. Staigmiller, and L.R. Corah. 1992. Management considerations in heifer development and puberty. J. Anim. Sci. 70:4018-4035.

Peters, J., ed. 2013. Wisconsin procedures for soil testing, plant analysis and feed and forage analysis, http://uwlab.soils.wisc.edu/lab-procedures/. University of Wisconsin-Madison Soil Testing Laboratories.

Poore, M. H., M. E. Scott, and J. T. Green Jr. 2006. Performance of beef heifers grazing stockpiled fescue as influenced by supplemental whole cottonseed. J. Anim. Sci. $84: 1613-1625$.

Riesterer, J.L., D.J. Undersander, M.D. Casler, and D.K. Combs. 2000b. Forage yield of stockpiled perennial grasses in the upper-Midwest USA. Agron. J. 92:740-747.

Roberts, A.J., T.W. Geary, E.E. Grings, R.C. Waterman and M.D. MacNeil. 2009. Reproductive performance of heifers offered ad libitum or restricted access to feed for a one hundred forty-day period after weaning. J. Anim. Sci. 87:3043-3052.

Shenk, J.S., and M.O. Westerhaus. 1991. Population structuring of near infrared spectra and modified partial least squares regression. Crop Sci. 31:1548-1555.

Tilley, J.M.A., and R.A. Terry. 1963. A two-stage technique for the in vitro digestion of forage crops. J. Brit. Grassl. Soc. 18:104-111. 
Van Soest, P.J. 1994. Nutritional ecology of the ruminant. $2^{\text {nd }}$ ed. Cornell University Press. Ithaca, NY.

Vazquez, O.P., and T.R. Smith. 2000. Factors affecting pasture intake and total dry matter intake in grazing dairy cows. J. Dairy Sci. 83:2301-2309.

Wagner, J. J., K. S. Lusby, J. W. Oltjen, J. Rakestraw, R. P. Wetteman, and L. E. Walters. 1988. Carcass composition in mature Hereford cows: Estimation and effect on daily Metabolizable energy requirement during winter. J. Anim. Sci. 66:603-612. 
Table 1. Regression equations relating clipped forage samples herbage mass with rising plate meter readings for the fall, spring and summer periods.

\begin{tabular}{cccccccc}
$\begin{array}{c}\text { Period and } \\
\text { Year }\end{array}$ & $\mathrm{n}$ & Equation & $\begin{array}{c}P \text {-value of } \mathrm{y} \text { - } \\
\text { intercept } \mathrm{I}^{\mathrm{N}}\end{array}$ & $\begin{array}{c}P \text {-value } \\
\text { of slope }\end{array}$ & $\begin{array}{c}\text { Root } \\
\text { MSE }\end{array}$ & $\mathrm{r}^{2}$ & $\mathrm{R}^{2}$ \\
\hline Fall Yr 1 & 96 & $\mathrm{y}^{2}=128 \mathrm{x}^{3}+1410$ & $<0.01$ & $<0.001$ & 1450 & 0.27 & - \\
Fall Yr 2 & 59 & $\mathrm{y}^{2}=228 \mathrm{x}^{3}$ & $(0.44)$ & $<0.001$ & 1107 & 0.92 & - \\
Fall Yr 3 & 36 & $\mathrm{y}^{2}=195 \mathrm{x}^{3}$ & $(0.07)$ & $<0.001$ & 1875 & 0.89 & - \\
Spring Yr 1 & 127 & $\mathrm{y}^{2}=183 \mathrm{x}-1.4 \mathrm{x}^{3}$ & $(0.45)$ & $<0.001$ & 1120 & 0.89 & - \\
Spring Yr 2 & 55 & $\mathrm{Y}^{2}=129 \mathrm{x}^{3}$ & $(0.60)$ & $<0.001$ & 920 & 0.93 & - \\
Spring Yr 3 & 10 & $\mathrm{y}^{2}=275 \mathrm{x}^{3}$ & $(0.23)$ & $<0.001$ & 1627 & 0.86 & - \\
Summer Yr 2 & 59 & $\mathrm{y}^{2}=256 \mathrm{x}-2.4 \mathrm{x}^{3}$ & $(0.19)$ & $<0.001$ & 1710 & & 0.94 \\
Summer Yr 3 & 58 & $\mathrm{y}^{2}=360 \mathrm{x}-6.1 \mathrm{x}^{3}$ & $(0.38)$ & $<0.001$ & 1031 & & 0.90
\end{tabular}

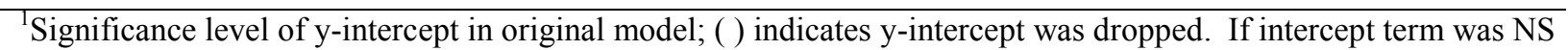
$(P \leq 0.05)$, regression was forced through origin.

${ }^{2} \mathrm{y}=$ herbage mass $(\mathrm{kg} \mathrm{DM} / \mathrm{ha})$

${ }^{3} \mathrm{X}=$ rising plate meter height units 
Table 2. Heifer descriptive statistics pooled across years.

\begin{tabular}{lcccc}
\multicolumn{1}{c}{ Trait } & Mean & SD & Minimum & Maximum \\
\hline Starting age, d & 232 & 17.5 & 180 & 272 \\
Initial BW, kg & 246 & 28.9 & 160 & 326 \\
Initial hip ht., cm & 109.3 & 4.8 & 100.3 & 119.4 \\
Initial BCS & 4.3 & 0.5 & 3.0 & 5.5 \\
Age at AI, d & 426 & 17.2 & 373 & 465 \\
BW at AI, kg & 345 & 37.4 & 243 & 463 \\
Final BW, kg & 409 & 35.7 & 291 & 520 \\
Hip ht. at AI, cm & 122 & 3.48 & 110 & 132 \\
\hline
\end{tabular}


Table 3. Long-term monthly mean rainfall, snowfall and temperature, and departures from the long-term mean in yr $1-$ yr $3^{1}$.

\begin{tabular}{|c|c|c|c|c|c|c|c|c|c|c|c|c|}
\hline Item & Aug & Sept & Oct & Nov & Dec & Jan & Feb & March & April & May & June & July \\
\hline \multicolumn{13}{|l|}{30 yr mean } \\
\hline Rain, mm & 107 & 97 & 90 & 104 & 86 & 153 & 69 & 98 & 103 & 134 & 122 & 129 \\
\hline Snow, mm & - & - & 8 & 96 & 324 & 1021 & 436 & 285 & 66 & - & - & - \\
\hline Avg. Temp, ${ }^{\circ} \mathrm{C}$ & 20.1 & 16.3 & 10.2 & 4.9 & -0.6 & -2.7 & -1.2 & 3.3 & 9.1 & 14.0 & 18.7 & 20.7 \\
\hline \multicolumn{13}{|l|}{ Yr 1 departure } \\
\hline Rain, $\mathrm{mm}$ & -14 & -19 & 43 & -71 & 12 & -72 & -69 & -37 & -49 & -4 & 54 & -66 \\
\hline Snow, mm & - & - & -8 & -58 & 324 & 122 & 2155 & -196 & -66 & - & - & - \\
\hline Avg. Temp, ${ }^{\circ} \mathrm{C}$ & 0.5 & 0.3 & -1.4 & 2.7 & -1.6 & -2.4 & -4.3 & 0.8 & 1.5 & 1.9 & 2.1 & 1.1 \\
\hline \multicolumn{13}{|l|}{ Yr 2 departure } \\
\hline Rain, mm & -30 & -2 & 3 & 9 & -42 & -144 & 4 & 43 & 125 & -51 & -21 & 32 \\
\hline Snow, mm & - & - & -8 & -96 & 508 & -94 & -258 & -221 & -28 & - & - & - \\
\hline Avg. Temp, ${ }^{\circ} \mathrm{C}$ & 1.1 & 1.3 & 0.1 & 0.3 & -5.7 & -2.9 & 0.9 & 0.3 & 1.9 & 2.3 & 0.8 & 1.9 \\
\hline \multicolumn{13}{|l|}{ Yr 3 departure } \\
\hline Rain, mm & 37 & 123 & 64 & 26 & 82 & -68 & 18 & 19 & -82 & 3 & -34 & -37 \\
\hline Snow, mm & - & - & -8 & -96 & -286 & -805 & -406 & -285 & -66 & - & - & - \\
\hline Avg. Temp, ${ }^{\circ} \mathrm{C}$ & 0.6 & 0.8 & -0.1 & 2.0 & 2.7 & 1.6 & 1.8 & 5.7 & -1.0 & 3.5 & 0.2 & 2.5 \\
\hline
\end{tabular}


Table 4. Mean herbage mass $( \pm \mathrm{SD})$ throughout the fall, spring and summer grazing periods.

\begin{tabular}{|c|c|c|c|c|}
\hline Item & & & Spring & Summer \\
\hline & $\mathrm{LO}$ & $\mathrm{HI}$ & & \\
\hline Herbage mass ${ }^{1}, \mathrm{~kg}$ DM/ha & $2,745 \pm 445$ & $2,696 \pm 400$ & $1,686 \pm 644$ & $3,061 \pm 864$ \\
\hline
\end{tabular}

${ }^{\mathrm{I}} \mathrm{DM}$ basis; $\mathrm{n}=9$ samples for each mean 
Table 5. Mean nutritional composition ( $\pm \mathrm{SD}$ ) of pastures during the fall, spring, and summer periods.

\begin{tabular}{|c|c|c|c|c|}
\hline \multirow[t]{2}{*}{ Item, $\%$ of DM } & \multicolumn{2}{|c|}{ Fall } & \multirow{2}{*}{ Spring } & \multirow[t]{2}{*}{ Summer } \\
\hline & LO & $\mathrm{HI}$ & & \\
\hline $\mathrm{CP}, \%$ & $17.3 \pm 2.7$ & $17.1 \pm 2.8$ & $24.4 \pm 4.1$ & $19.5 \pm 4.1$ \\
\hline $\mathrm{NDF}^{1}, \%$ & $52.3 \pm 3.9$ & $51.3 \pm 4.4$ & $48.5 \pm 7.0$ & $53.6 \pm 4.9$ \\
\hline IVTDMD $48^{2}, \%$ & $78.1 \pm 5.0$ & $78.4 \pm 4.4$ & $84.2 \pm 6.8$ & $78.3 \pm 5.8$ \\
\hline $\mathrm{TDN}^{3}, \%$ & $66.5 \pm 3.7$ & $66.9 \pm 3.8$ & $67.6 \pm 6.1$ & $63.5 \pm 5.6$ \\
\hline $\mathrm{ADF}^{4}, \%$ & $30.0 \pm 4.3$ & $29.9 \pm 3.9$ & $29.0 \pm 5.9$ & $33.4 \pm 4.5$ \\
\hline $\mathrm{EE}^{5}, \%$ & 2.10 .4 & $2.1 \pm 0.4$ & $2.5 \pm 0.7$ & $2.5 \pm 0.7$ \\
\hline Ash, $\%$ & $7.4 \pm 1.1$ & $7.5 \pm 1.3$ & $9.5 \pm 1.7$ & $8.0 \pm 1.3$ \\
\hline $\begin{array}{l}\mathrm{n}=33 \text { samples }(\mathrm{f} \\
{ }^{1} \mathrm{NDF}=\text { neutral } \\
{ }^{2} \mathrm{IVTDMD} \\
{ }^{3} \mathrm{TDN}=\text { total dig } \\
{ }^{4} \mathrm{ADF}=\text { acid dete } \\
{ }^{5} \mathrm{EE}=\text { ether extra }\end{array}$ & $\begin{array}{l}\text { es (spring), a } \\
\text { matter dige }\end{array}$ & (summer) & & \\
\hline
\end{tabular}


Table 6. Mean nutritional composition ( \pm SD) of haylage and soybean hulls.

\begin{tabular}{lcc} 
Item, \% of DM & Haylage & Soybean Hulls \\
\hline $\mathrm{CP}^{1}, \%$ & $12.0 \pm 2.4$ & $14.8 \pm 1.6$ \\
$\mathrm{NDF}^{2}, \%$ & $61.3 \pm 5.1$ & $61.9 \pm 2.4$ \\
$\mathrm{IVTDM}^{2}$ & $71.7 \pm 4.3$ & - \\
$\mathrm{TDN}^{4}, \%$ & $59.3 \pm 2.5$ & - \\
$\mathrm{ADF}^{5}, \%$ & $40.6 \pm 2.5$ & $45.3 \pm 2.2$ \\
$\mathrm{EE}^{6}, \%$ & $2.5 \pm 0.6$ & $2.4 \pm 0.3$ \\
Ash, \% & $7.9 \pm 2.0$ & $4.2 \pm 0.3$ \\
\hline
\end{tabular}

${ }^{\mathrm{I}}$ Crude protein

${ }^{2} \mathrm{NDF}=$ neutral detergent fiber

${ }^{3}$ IVTDMD48 = in vitro true dry matter digestibility

${ }^{4} \mathrm{TDN}=$ total digestible nutrients

${ }^{5} \mathrm{ADF}=$ acid detergent fiber

${ }^{6} \mathrm{EE}=$ ether extract 
Table 7. Effects of fall forage allocation (HI vs LO) and period on heifer BW gain and BW.

\begin{tabular}{|c|c|c|c|c|}
\hline Trait & $\mathrm{LO}^{1}$ & $\mathrm{HI}^{2}$ & SEM & $P$-value \\
\hline $\mathrm{n}$ & 3 & 3 & - & - \\
\hline Initial BW, kg & 246 & 245 & 2.90 & 0.93 \\
\hline Initial BCS & 4.3 & 4.3 & 0.08 & 0.50 \\
\hline Initial hip ht., cm & 109.2 & 109.0 & 1.88 & 0.68 \\
\hline Fall period $A D G, k g / d^{3}$ & 0.12 & 0.40 & 0.04 & $<0.0001$ \\
\hline Winter period $\mathrm{ADG}, \mathrm{kg} / \mathrm{d}^{4}$ & 0.30 & 0.39 & 0.04 & $<0.01$ \\
\hline Spring period $\mathrm{ADG}, \mathrm{kg} / \mathrm{d}^{5}$ & 1.39 & 1.31 & 0.05 & 0.64 \\
\hline Summer ADG, $\mathrm{kg} / \mathrm{d}^{7}$ & 0.74 & 0.67 & 0.04 & $<0.05$ \\
\hline $\mathrm{BW}$ at breeding, $\mathrm{kg}$ & 335 & 356 & 10.0 & $<0.0001$ \\
\hline $\mathrm{BCS}$ at breeding & 5.6 & 5.8 & 0.10 & $<0.01$ \\
\hline Hip ht at breeding, cm & 121.4 & 122.7 & 0.13 & $<0.01$ \\
\hline Treatment initiation to breeding $\mathrm{ADG}, \mathrm{kg} / \mathrm{d}^{6}$ & 0.46 & 0.56 & 0.04 & $<0.001$ \\
\hline Pregnancy diagnosis BW, kg & 402 & 415 & 10.2 & $<0.01$ \\
\hline Treatment initiation to pregnancy diagnosis $\mathrm{ADG}, \mathrm{kg} / \mathrm{d}^{8}$ & 0.55 & 0.61 & 0.04 & $<0.001$ \\
\hline Treatment $\mathrm{x}$ Period interaction & & & & $<0.0001$ \\
\hline
\end{tabular}

${ }^{1} \mathrm{LO}=$ daily pasture DM allowance of $3.5 \%$ of $\mathrm{BW}$

${ }^{2} \mathrm{HI}=$ daily pasture $\mathrm{DM}$ allowance of $7.0 \%$ of BW

${ }^{3} \mathrm{ADG}$ while grazing fall stockpiled forage

${ }^{4} \mathrm{ADG}$ during the winter feeding period

${ }^{5} \mathrm{ADG}$ during the spring grazing period

${ }^{6} \mathrm{ADG}$ in the period between treatment initiation and breeding

${ }^{7} \mathrm{ADG}$ during the summer grazing period

${ }^{8} \mathrm{ADG}$ in the period between treatment initiation and pregnancy diagnosis 
Table 8. Effects of fall forage allocation (HI vs LO) on heifer reproduction.

\begin{tabular}{|c|c|c|c|c|}
\hline Trait & LOW $^{1}$ & $\mathrm{HIGH}^{2}$ & SEM & $P$-value \\
\hline $\mathrm{n}$ & 3 & 3 & - & - \\
\hline Pubertal by AI, \% & 34 & 34 & 0.13 & 0.93 \\
\hline Pregnant to AI, \% & 32 & 44 & 0.08 & 0.13 \\
\hline Pregnant to Bull ${ }^{3}, \%$ & 61 & 59 & 0.06 & 0.80 \\
\hline Final pregnancy rate, $\%$ & 74 & 77 & 0.05 & 0.61 \\
\hline
\end{tabular}

${ }^{1} \mathrm{LO}=$ daily pasture $\mathrm{DM}$ allowance of $3.5 \%$ of $\mathrm{BW}$

${ }^{2} \mathrm{HI}=$ daily pasture DM allowance of $7.0 \%$ of $\mathrm{BW}$

${ }^{3}$ Expressed as percentage of heifers eligible to become pregnant 
Figure 1. Growth patterns (ADG) of $\mathrm{LO}$ and $\mathrm{HI}$ heifers during the fall, winter, spring and summer periods $(\mathrm{LO}=$ daily pasture $\mathrm{DM}$ allowance of $3.5 \%$ of $\mathrm{BW}$; $\mathrm{HI}=$ daily pasture $\mathrm{DM}$ allowance of $7.0 \%$ of BW).

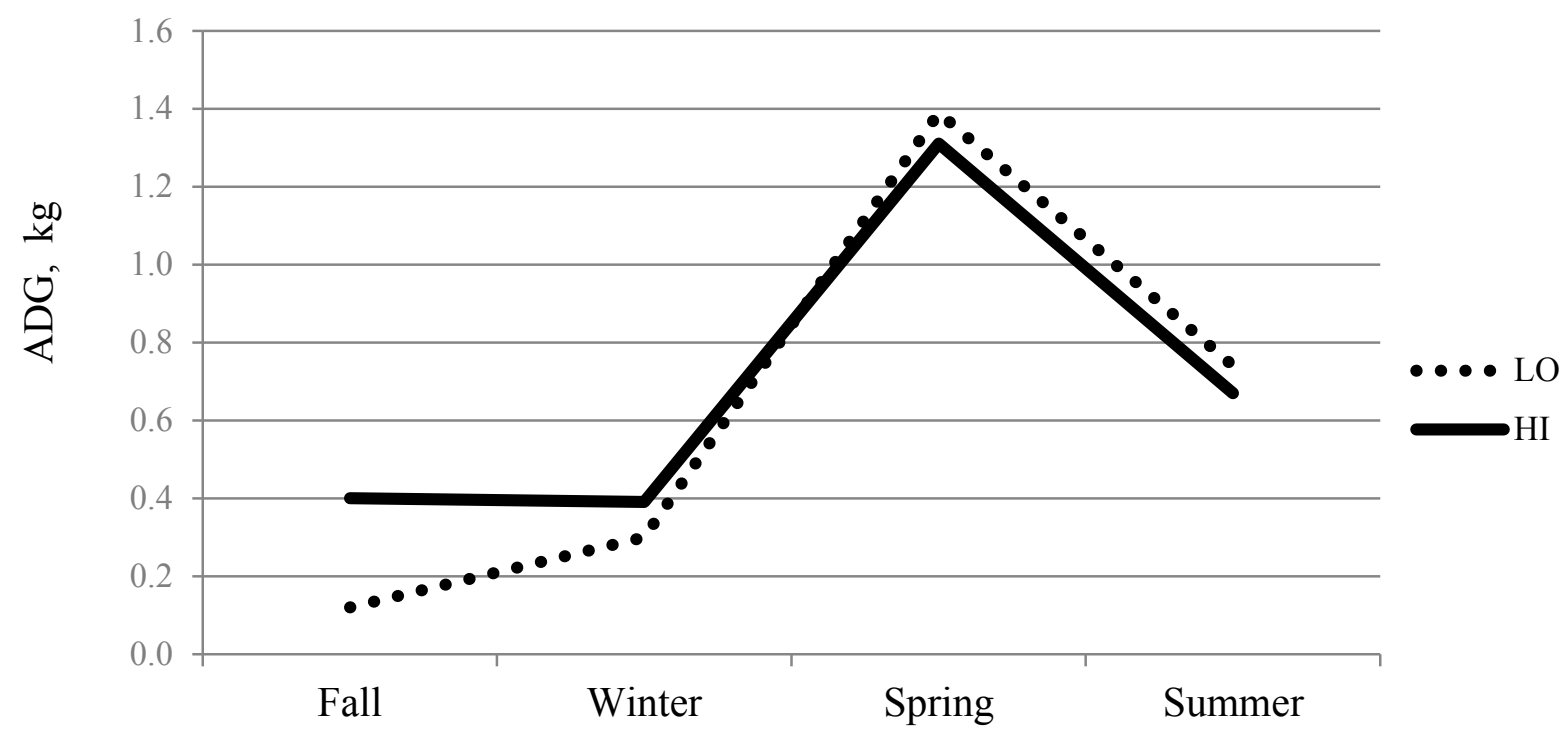


Figure 2. The predicted probability of heifers becoming pregnant to AI based on fall ADG. The triangle $(\boldsymbol{\Delta})$ indicates the predicted probability of pregnancy by $\mathrm{AI}$ and the upper and lower lines refer to the $95 \% \mathrm{CI}$.

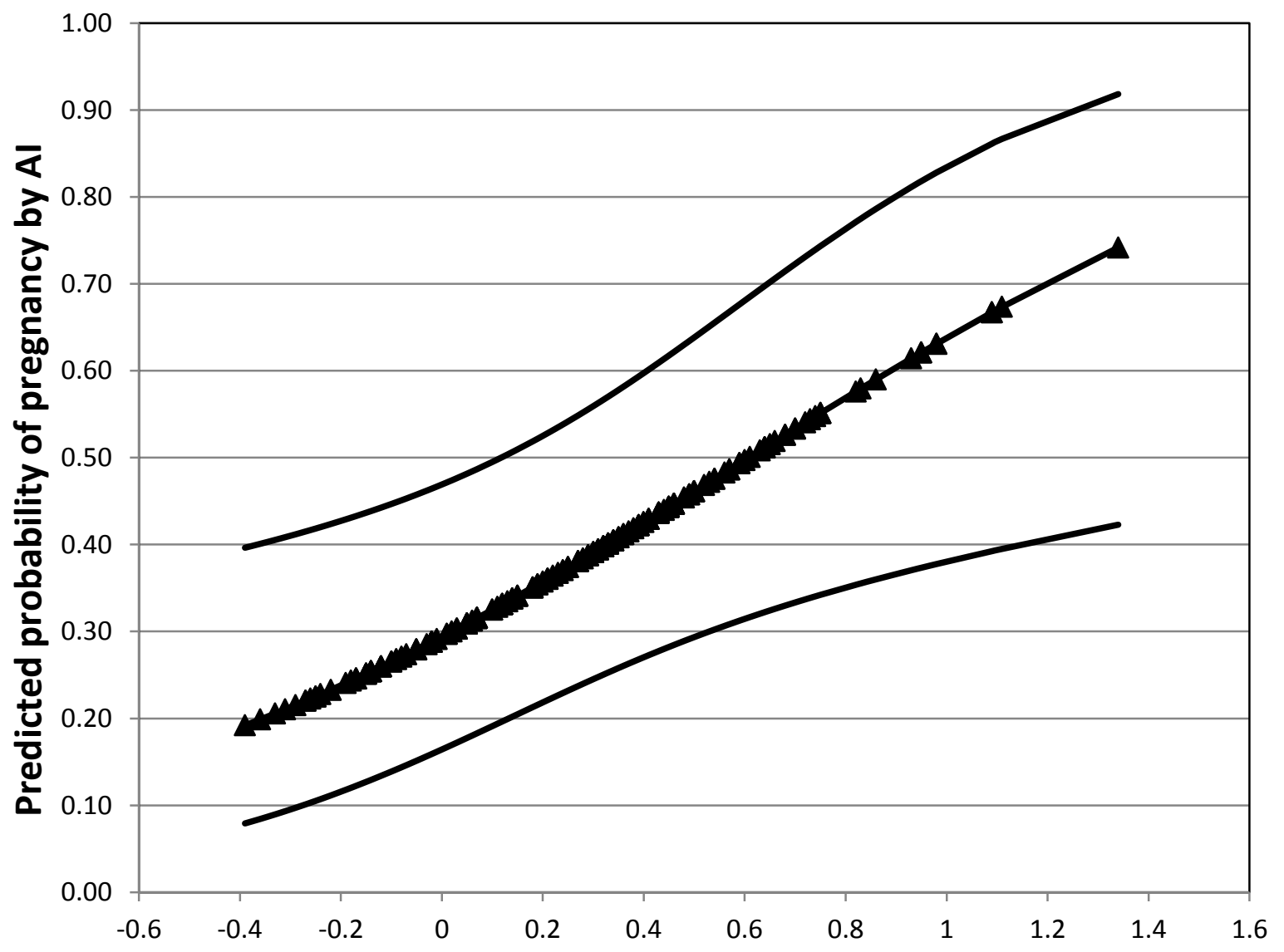

Fall ADG, $\mathbf{k g}$ 


\section{GENERAL SUMMARY}

Small profit margins in animal production systems have emphasized the need for more extensive use of pastures by livestock producers. With beef cattle producers looking for ways to reduce the feed costs, stockpiling forages has become of interest. Development of beef heifers to become replacement breeding animals is extremely important for the beef cattle industry. Recent research on heifer development systems has been conducted primarily in dry-lot settings and there is limited information comparing systems which utilize stockpiled forages to extend the grazing system.

Forage systems in Appalachia are based on cool-season grasses such as tall fescue, orchardgrass, white clover, and red clover. The potential of tall fescue and orchardgrass as stockpiled forages have been extensively documented. Research has demonstrated that tall fescue has the ability to maintain quality throughout the fall and early winter better than other grasses. Less is known about the stockpiling characteristics of other grasses and legumes, especially naturalized pastures containing complex mixtures.

For the first objective of the study, we found that there was no significant effect of HI vs. LO stocking rates on botanical composition, herbage mass, or forage quality. Average stockpiled herbage mass in the pastures compared favorably with yields of tall fescue and orchardgrass. Distribution of DM yield and botanical composition from year 1 to 3 and throughout the fall grazing periods was influenced primarily by climatic conditions and grazing management (stocking rate). Nutritive content of the pastures was adequate to meet the requirements of beef heifers. This study demonstrated that mixed cool-season naturalized pastures can be utilized for stockpiling and grazed intensively without detrimental effects to subsequent stockpiling periods. 
For the second objective of the study, heifers in the HI treatment group had higher ADG than those in the LO group during the fall and winter periods. A relationship between fall ADG and NDF content of pasture was detected. For each 1 percentage unit increase in NDF, fall ADG decreased $0.14 \mathrm{~kg}$. During the spring and summer grazing periods, heifers in the LO group compensated with greater ADG than heifers in the HI group. This compensatory gain was also evidenced by the decrease in $\mathrm{BW}$ difference between $\mathrm{LO}$ and $\mathrm{HI}$ at the end of the spring grazing period vs. the end of the summer period: at the end of spring heifers in the HI group weighed an average of $21 \mathrm{~kg}$ more than heifers in the LO group, but by the end of the summer grazing period this difference had been decreased to $13 \mathrm{~kg}$. Fall pasture allowance did not affect percentage of heifers reaching puberty by the time of AI; $34 \%$ of heifers in both groups reached puberty by the time of AI. Pregnancy rates for AI tended to be higher for HI heifers (44\%) than for LO heifers (32\%). It was noted that fall ADG across treatment groups affected the probability of a heifer becoming pregnant by AI. As ADG increased $1 \mathrm{~kg}$, the odds of a heifer becoming pregnant to AI increased. The probability of a heifer becoming pregnant by AI with ADG in the fall of $0 \mathrm{~kg}$, $0.5 \mathrm{~kg}$, and $1.0 \mathrm{~kg}$ is $29 \%, 46 \%$, and $64 \%$, respectively. The percentage of heifers becoming pregnant to the bull was similar for both treatment groups (61\% for LO vs. $59 \%$ for $\mathrm{HI}$ ) as was final pregnancy rate ( $74 \%$ for $\mathrm{LO}$ vs. $77 \%$ for $\mathrm{HI})$. This study indicates that delaying the majority of weight gain until late in heifer development may decrease costs of winter feeding without detrimental effects on overall reproductive performance; however, fall ADG may affect first service conception rates.

Overall, these studies demonstrate that mixed cool-season naturalized pastures can be effectively stockpiled for fall and winter grazing and delaying the majority of heifer BW gain until 35-44 days prior to breeding have the potential to result in adequate overall pregnancy rates. 
Also, heifers raised on pasture based systems that are not pregnant and therefore not kept as replacements could be sold as "Pasture Raised Beef". Although it may be impractical to totally remove stored feeds from winter feeding system, utilizing stockpiled forages to increase the number of days that grazing can replace stored feed has the potential to reduce costs of production while still achieving acceptable heifer performance. 
APPENDIX 
Figure 1. Snowfall amounts (2009-2012)

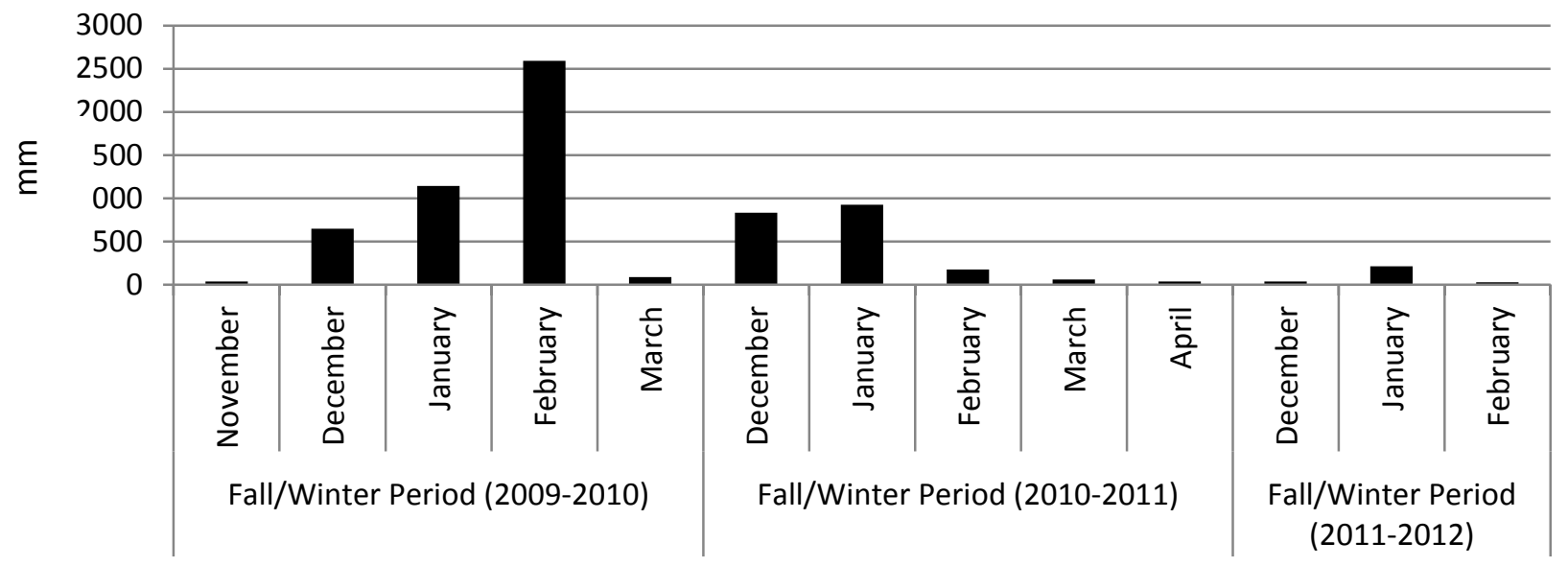


Figure 2. Rainfall amounts (2009-2012)

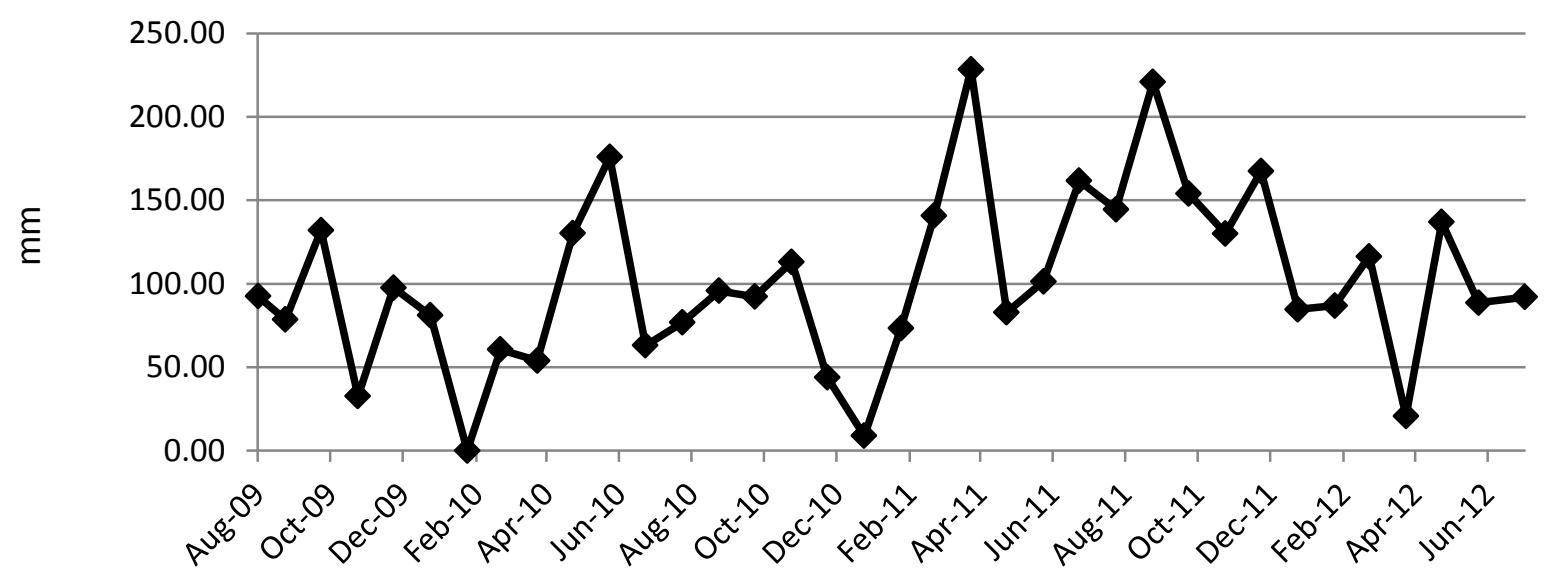

105 
Figure 3. Average Temperature (2009-2012)

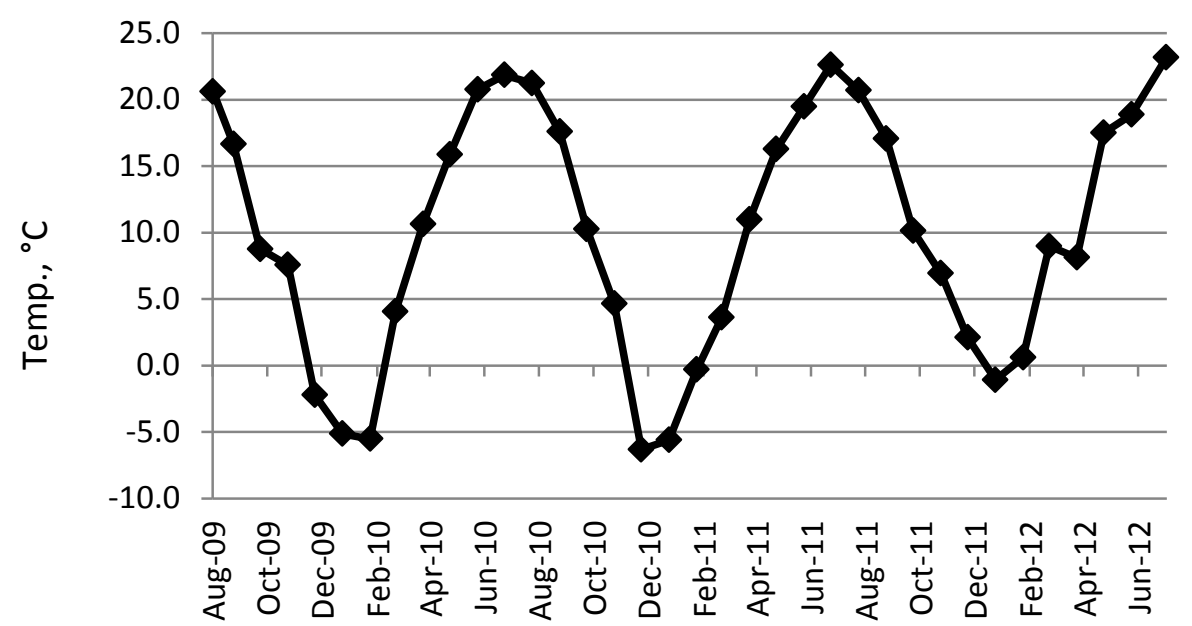


Table 1. Long-term monthly mean rainfall, snowfall and temperature, and departures from the long-term mean in yr 1 - yr $3^{1}$

\begin{tabular}{|c|c|c|c|c|c|c|c|c|c|c|c|c|c|c|c|c|c|c|c|c|}
\hline & \multicolumn{5}{|c|}{ 30-yr mean } & \multicolumn{5}{|c|}{ Yr 1 departure } & \multicolumn{5}{|c|}{ Yr 2 departure } & \multicolumn{5}{|c|}{ Yr 3 departure } \\
\hline Month & $\begin{array}{c}\text { Rain } \\
\text { mm }\end{array}$ & $\begin{array}{c}\text { Snow } \\
\text { mm }\end{array}$ & ${ }^{{ }^{\circ} \mathrm{C}}{ }^{2}$ & $\begin{array}{c}\operatorname{Max}^{2} \\
{ }^{\circ} \mathrm{C}\end{array}$ & $\begin{array}{c}\text { Avg } \\
\text { Temp } \\
{ }^{\circ} \mathrm{C}\end{array}$ & $\begin{array}{l}\text { Rain } \\
\text { mm }\end{array}$ & $\begin{array}{c}\text { Snow } \\
\text { mm }\end{array}$ & $\begin{array}{c}\mathrm{Min}^{2} \\
{ }^{\circ} \mathrm{C}\end{array}$ & $\begin{array}{c}\operatorname{Max}^{2} \\
{ }^{\circ} \mathrm{C}\end{array}$ & $\begin{array}{c}\text { Avg } \\
\text { Temp } \\
{ }^{\circ} \mathrm{C}\end{array}$ & $\begin{array}{c}\text { Rain } \\
\text { mm }\end{array}$ & $\begin{array}{c}\text { Snow } \\
\text { mm }\end{array}$ & $\begin{array}{c}\operatorname{Min}^{2} \\
{ }^{\circ} \mathrm{C}\end{array}$ & $\begin{array}{c}\operatorname{Max}^{2} \\
{ }^{\circ} \mathrm{C}\end{array}$ & $\begin{array}{c}\text { Avg } \\
\text { Temp } \\
{ }^{\circ} \mathrm{C}\end{array}$ & $\begin{array}{l}\text { Rain } \\
\text { mm }\end{array}$ & $\begin{array}{c}\text { Snow } \\
\mathrm{mm}\end{array}$ & ${ }^{{ }^{\circ} \mathrm{C}}{ }^{2}$ & $\begin{array}{c}\operatorname{Max}^{2} \\
{ }^{\circ} \mathrm{C}\end{array}$ & $\begin{array}{c}\text { Avg } \\
\text { Temp } \\
{ }^{\circ} \mathrm{C}\end{array}$ \\
\hline Aug & 107 & - & 14.0 & 26.1 & 20.1 & -14 & - & -6.2 & 5.0 & 0.5 & -30 & - & -4.6 & 5.0 & 1.1 & 37 & - & -2.9 & 5.0 & 0.6 \\
\hline Sept & 97 & - & 9.8 & 22.8 & 16.3 & -19 & - & -6.5 & 6.1 & 0.3 & -2 & - & -7.0 & 9.4 & 1.3 & 123 & - & -8.7 & 8.9 & 0.8 \\
\hline Oct & 90 & 8 & 10.2 & 17.0 & 10.2 & 43 & -8 & -3.6 & 6.3 & -1.4 & 3 & -8 & -15.2 & 8.6 & 0.1 & 64 & -8 & -13.0 & 9.1 & -0.1 \\
\hline Nov & 104 & 96 & -0.9 & 16.4 & 4.9 & -71 & -58 & -4.7 & 4.2 & 2.7 & 9 & -96 & -9.1 & 4.7 & 0.3 & 26 & -96 & -6.9 & 4.7 & 2.0 \\
\hline Dec & 86 & 324 & -5.7 & 4.4 & -0.6 & 12 & 324 & -13.7 & 10.0 & -1.6 & -42 & 508 & -15.4 & 9.5 & -5.7 & 82 & -286 & -7.1 & 13.4 & 2.7 \\
\hline Jan & 153 & 1021 & -7.9 & 2.4 & -2.7 & -72 & 122 & -16.5 & 9.8 & -2.4 & -144 & -94 & -16.5 & 9.3 & -2.9 & -68 & -805 & -14.3 & 13.2 & 1.6 \\
\hline Feb & 69 & 436 & -6.8 & 4.4 & -1.2 & -69 & 2155 & -15.4 & 1.2 & -4.3 & 4 & -258 & -15.4 & 13.9 & 0.9 & 18 & -406 & -8.8 & 11.2 & 1.8 \\
\hline March & 98 & 285 & -2.8 & 9.4 & 3.3 & -37 & -196 & -12.8 & 11.7 & 0.8 & 43 & -221 & -6.6 & 10.6 & 0.3 & 19 & -285 & -9.4 & 18.4 & 5.7 \\
\hline April & 103 & 66 & 2.2 & 16.0 & 9.1 & -49 & -66 & -5.5 & 12.9 & 1.5 & 125 & -28 & -5.5 & 10.7 & 1.9 & -82 & -66 & -7.8 & 21.8 & -1.0 \\
\hline May & 134 & - & 7.4 & 20.6 & 14.0 & -4 & - & -11.8 & 8.3 & 1.9 & -51 & - & -8.5 & 9.4 & 2.3 & 3 & - & -8.5 & 10.5 & 3.5 \\
\hline June & 122 & - & 12.5 & 24.8 & 18.7 & 54 & - & -9.2 & 4.6 & 2.1 & -21 & - & -7.5 & 6.3 & 0.8 & -34 & - & -7.5 & 8.5 & 0.2 \\
\hline July & 129 & - & 14.9 & 26.6 & 20.7 & -66 & - & -9.3 & 5.6 & 1.1 & 32 & - & -1.9 & 7.8 & 1.9 & -37 & - & -3.2 & 10.6 & 2.5 \\
\hline
\end{tabular}

${ }^{1}$ Rainfall, snowfall and temperature during yr 1 - yr 3and 30-yr (1980-2010) mean measured on-site

${ }^{2} \mathrm{Max}{ }^{\circ} \mathrm{C}=$ monthly mean high temperature; and Min ${ }^{\circ} \mathrm{C}=$ monthly mean low temperature 
Table 2. Soil test results for fields 1-3 for yr 1-3 (sampling depth $=5-8 \mathrm{~cm}$ ).

\begin{tabular}{|c|c|c|c|c|c|c|c|c|c|c|c|c|}
\hline \multirow[b]{2}{*}{ Field } & \multicolumn{4}{|c|}{ Yr 1} & \multicolumn{4}{|c|}{ Yr 2} & \multicolumn{4}{|c|}{ Yr 3} \\
\hline & $\mathrm{P}^{\mathrm{a}}$ & $\mathrm{K}^{\mathrm{b}}$ & $\mathrm{pH}$ & $\mathrm{OM} \%{ }^{\mathrm{c}}$ & $\mathrm{P}^{\mathrm{a}}$ & $\mathrm{K}^{\mathrm{b}}$ & $\mathrm{pH}$ & $\mathrm{OM} \%{ }^{\mathrm{c}}$ & $\mathrm{P}^{\mathrm{a}}$ & $\mathrm{K}^{\mathrm{b}}$ & $\mathrm{pH}$ & $\mathrm{OM} \%{ }^{\mathrm{c}}$ \\
\hline 1 & 27 & 144 & 6.2 & 7.4 & 29 & 260 & 6.4 & 7.2 & 27 & 232 & 5.8 & 9.9 \\
\hline 2 & 27 & 166 & 6.7 & 8.4 & 19 & 169 & 6.6 & 8.5 & 20 & 132 & 5.8 & 10.3 \\
\hline 3 & 25 & 202 & 6.4 & 9.0 & 20 & 205 & 6.2 & 9.1 & 35 & 194 & 5.5 & 10.0 \\
\hline
\end{tabular}

${ }^{\mathrm{a}} \mathrm{P}=$ phosphorus levels in ppm in soil

${ }^{\mathrm{b}} \mathrm{K}=$ potassium levels in ppm in soil

${ }^{\mathrm{c}} \mathrm{OM}=\%$ organic matter in soil 
Figure 4. Changes in \% red and white clover concentrations in HI and LO treatments for yr 1-3 $(\mathrm{LO}=$ daily pasture $\mathrm{DM}$ allowance of $3.5 \%$ of $\mathrm{BW}, \mathrm{HI}=$ daily pasture allowance of $7.0 \%$ of $\mathrm{BW})$.

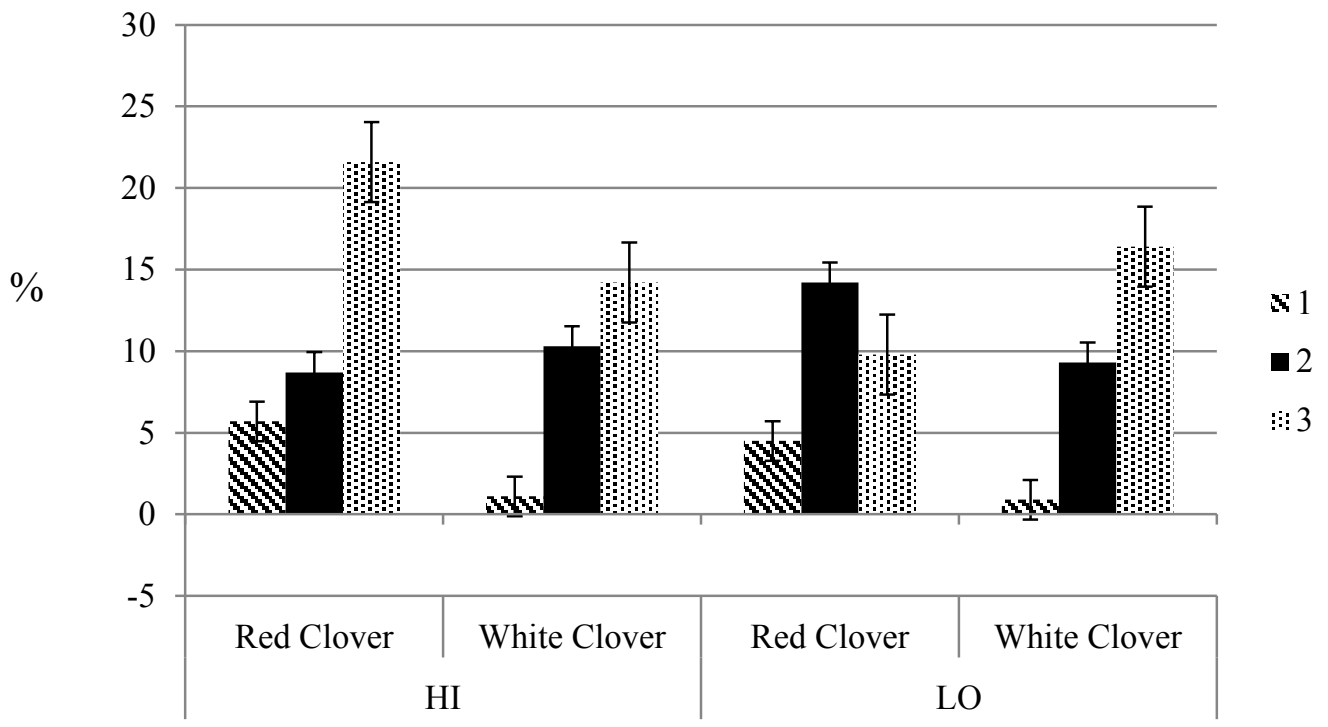


Figure 5. \% Non-legume forbs in $\mathrm{HI}$ and LO pasture treatments for yr 1-3 (LO = daily pasture DM allowance of $3.5 \%$ of BW, HI - daily pasture allowance of $7.0 \%$ of BW).

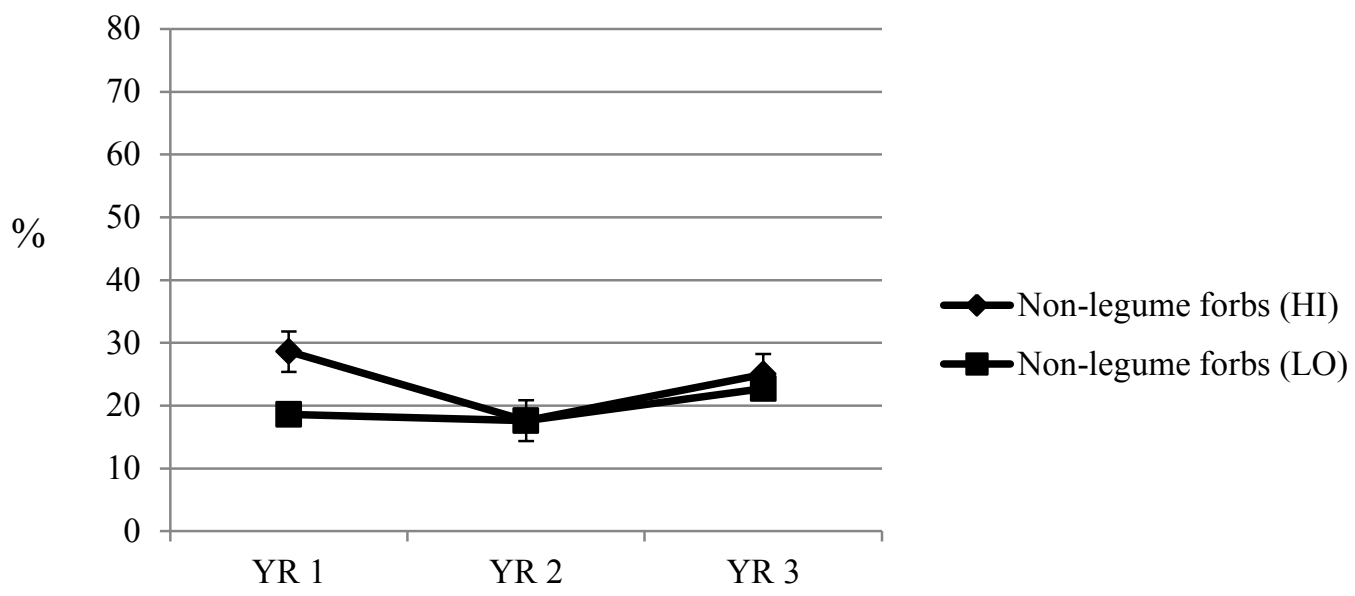


Figure 6. \% Legumes in $\mathrm{HI}$ and LO pasture treatments for yr 1-3 (LO = daily pasture DM allowance of $3.5 \%$ of BW, $\mathrm{HI}=$ daily pasture allowance of $7.0 \%$ of BW).

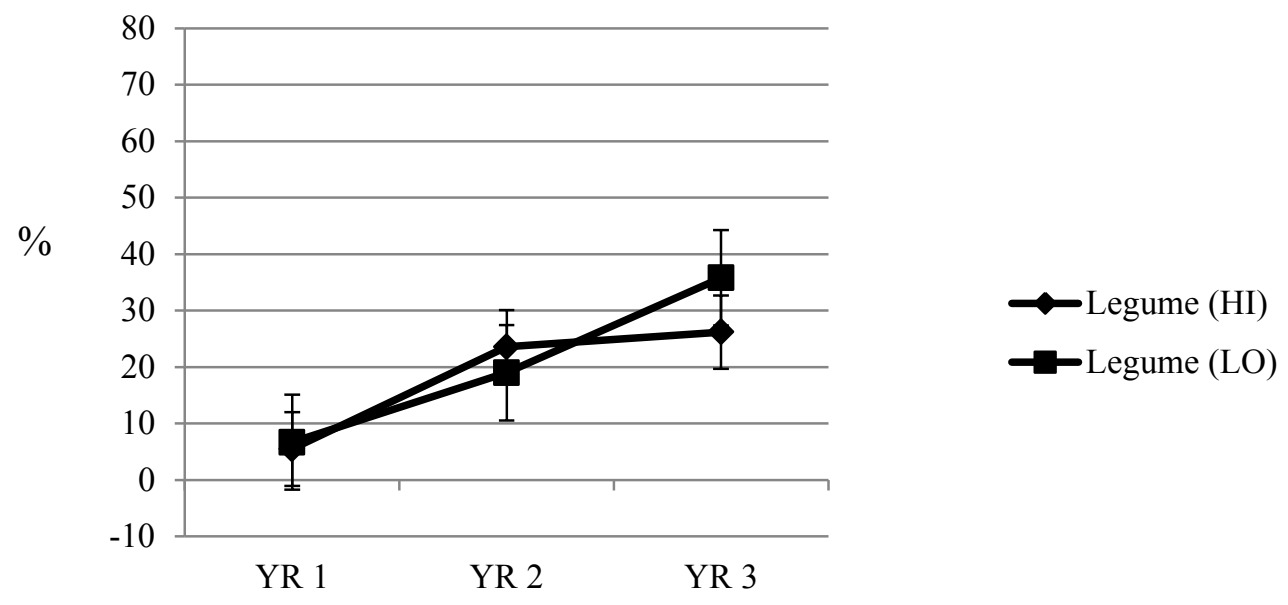


Figure 7. \% Grass in $\mathrm{HI}$ and LO pasture treatments for yr 1-3 (LO = daily pasture DM allowance of $3.5 \%$ of $\mathrm{BW}, \mathrm{HI}=$ daily pasture allowance of $7.0 \%$ of $\mathrm{BW}$ ).

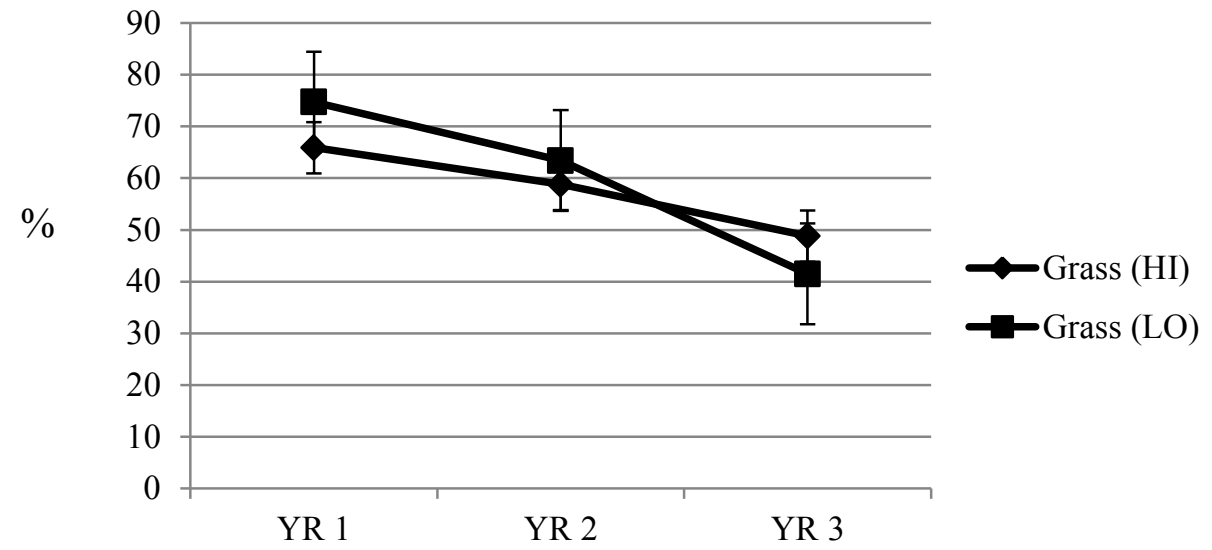


Table 3. Mean nutritional composition $( \pm \mathrm{SD})$ of pastures, haylage and soy hulls.

\begin{tabular}{|c|c|c|c|c|c|c|c|}
\hline Item $^{2}$ & & $\begin{array}{l}\text { Fall pasture } \\
{\text { (LO) })^{1}}^{\text {a }}\end{array}$ & $\begin{array}{l}\text { Fall Pasture } \\
(\mathrm{HI})^{1}\end{array}$ & Spring Pasture & $\begin{array}{l}\text { Summer } \\
\text { Pasture }\end{array}$ & Haylage & Soy Hulls \\
\hline \multicolumn{8}{|l|}{$\mathrm{CP}, \%$} \\
\hline & Yr 1 & $15.9 \pm 1.8$ & $15.6 \pm 1.8$ & $23.4 \pm 4.6$ & $20.1 \pm 1.6$ & $13.5 \pm 3.0$ & $15.5 \pm 0.8$ \\
\hline & Yr 2 & $19.8 \pm 2.6$ & $19.1 \pm 3.0$ & $26.0 \pm 4.4$ & $20.2 \pm 2.1$ & $10.9 \pm 0.4$ & $15.6 \pm 0.9$ \\
\hline & Yr 3 & $16.9 \pm 2.4$ & $17.1 \pm 2.4$ & $25.1 \pm 2.2$ & $19.3 \pm 4.7$ & $10.8 \pm 1.2$ & $11.6 \pm 0.1$ \\
\hline \multicolumn{8}{|l|}{$\mathrm{ADF}^{3} \%$} \\
\hline & Yr 1 & $31.3 \pm 2.1$ & $31.5 \pm 1.9$ & $30.3 \pm 5.8$ & $29.8 \pm 0.7$ & $40.7 \pm 2.5$ & $44.3 \pm 1.0$ \\
\hline & Yr 2 & $26.4 \pm 3.5$ & $26.6 \pm 3.4$ & $31.5 \pm 5.0$ & $37.3 \pm 2.2$ & $41.4 \pm 1.4$ & $48.6 \pm 1.7$ \\
\hline & Yr 3 & $31.8 \pm 4.6$ & $30.9 \pm 4.2$ & $24.8 \pm 4.0$ & $32.4 \pm 4.4$ & $39.9 \pm 3.3$ & $44.0 \pm 0.1$ \\
\hline \multicolumn{8}{|c|}{$\mathrm{NDF}^{4}, \%$} \\
\hline & Yr 1 & $53.1 \pm 2.8$ & $53.0 \pm 3.7$ & $50.9 \pm 7.9$ & $54.1 \pm 2.2$ & $60.4 \pm 6.9$ & $60.2 \pm 1.5$ \\
\hline & Yr 2 & $50.9 \pm 3.3$ & $49.1 \pm 4.1$ & $44.6 \pm 5.1$ & $50.5 \pm 3.4$ & $62.3 \pm 3.3$ & $63.5 \pm 0.7$ \\
\hline & Yr 3 & $52.4 \pm 4.9$ & $51.4 \pm 4.5$ & $47.7 \pm 4.6$ & $54.5 \pm 5.1$ & $63.0 \pm 3.6$ & $65.4 \pm 0.4$ \\
\hline \multicolumn{8}{|c|}{ NDFD $48^{5}, \%$} \\
\hline & Yr 1 & $61.8 \pm 2.6$ & $61.4 \pm 2.8$ & $65.9 \pm 7.5$ & $65.0 \pm 2.1$ & $53.9 \pm 4.4$ & - \\
\hline & Yr 2 & $69.3 \pm 4.7$ & $67.7 \pm 5.0$ & $70.5 \pm 4.1$ & $57.1 \pm 5.0$ & $52.4 \pm 3.6$ & - \\
\hline & Yr 3 & $61.3 \pm 4.4$ & $63.2 \pm 3.9$ & $68.7 \pm 3.0$ & $58.6 \pm 10.1$ & $51.6 \pm 0.0$ & - \\
\hline \multicolumn{8}{|c|}{ IVTDMD $48^{6} \%$} \\
\hline & Yr 1 & $77.1 \pm 3.4$ & $77.8 \pm 3.4$ & $81.4 \pm 8.6$ & $80.7 \pm 1.6$ & $73.2 \pm 5.4$ & - \\
\hline & Yr 2 & $80.5 \pm 4.2$ & $79.4 \pm 3.8$ & $86.2 \pm 2.8$ & $77.9 \pm 3.2$ & $69.9 \pm 2.2$ & - \\
\hline & Yr 3 & $77.5 \pm 6.2$ & $78.3 \pm 5.5$ & $87.3 \pm 2.2$ & $78.2 \pm 6.5$ & $71.3 \pm 0.0$ & - \\
\hline \multicolumn{8}{|c|}{$\mathrm{dNDF} 48^{7}, \%$} \\
\hline & Yr 1 & $31.6 \pm 2.3$ & $30.9 \pm 2.6$ & $30.8 \pm 4.2$ & $35.0 \pm 0.3$ & $30.9 \pm 1.1$ & - \\
\hline & Yr 2 & $33.8 \pm 1.7$ & $32.8 \pm 2.1$ & $32.7 \pm 4.0$ & $28.4 \pm 3.2$ & $33.2 \pm 2.4$ & - \\
\hline & Yr 3 & $31.4 \pm 2.1$ & $32.0 \pm 2.6$ & $31.8 \pm 2.0$ & $31.6 \pm 4.8$ & $30.7 \pm 0.0$ & - \\
\hline \multicolumn{8}{|c|}{$\mathrm{TDN}^{8}, \%$} \\
\hline & Yr 1 & $65.3 \pm 1.9$ & $64.7 \pm 3.2$ & $65.6 \pm 7.4$ & $66.4 \pm 1.2$ & $56.2 \pm 0.9$ & - \\
\hline & Yr 2 & $69.9 \pm 3.2$ & $70.1 \pm 2.7$ & $71.8 \pm 2.2$ & $64.7 \pm 3.7$ & $57.8 \pm 0.5$ & - \\
\hline \multirow{2}{*}{\multicolumn{8}{|c|}{$\mathrm{EE}^{9}, \%$}} \\
\hline & & & & & & & \\
\hline & Yr 1 & $1.9 \pm 0.3$ & $1.8 \pm 0.2$ & $2.4 \pm 0.4$ & $2.5 \pm 0.2$ & $2.6 \pm 0.7$ & $2.5 \pm 0.2$ \\
\hline & Yr 2 & $2.4 \pm 0.3$ & $2.4 \pm 0.3$ & $3.2 \pm 0.9$ & $3.0 \pm 0.6$ & $2.5 \pm 0.3$ & $2.3 \pm 0.2$ \\
\hline & Yr 3 & $2.1 \pm 0.4$ & $2.1 \pm 0.4$ & $2.1 \pm 0.7$ & $2.2 \pm 0.8$ & $2.5 \pm 1.1$ & $2.0 \pm 0.0$ \\
\hline \multicolumn{8}{|l|}{ Ash, \% } \\
\hline & Yr 2 & $7.5 \pm 1.4$ & $7.0 \pm 0.7$ & $8.6 \pm 0.8$ & $7.8 \pm 1.2$ & $5.9 \pm 0.9$ & $4.6 \pm 0.2$ \\
\hline & Yr 3 & $7.6 \pm 0.8$ & $7.5 \pm 0.9$ & $9.8 \pm 1.3$ & $8.0 \pm 1.3$ & $8.5 \pm 0.9$ & $3.8 \pm 0.0$ \\
\hline
\end{tabular}

Treatments: $\mathrm{LO}=$ daily pasture DM allowance of $3.5 \%$ of $\mathrm{BW}, \mathrm{HI}=$ daily pasture allowance of $7.0 \%$ of $\mathrm{BW}$.

${ }^{2}$ Values reported on a percent DM basis

${ }^{3} \mathrm{ADF}=$ acid detergent fiber ${ }^{4} \mathrm{NDF}=$ neutral detergent fiber; ${ }^{5} \mathrm{NDFD} 48=$ neutral detergent fiber digestibility,

${ }^{6}$ IVTDMD48 = in vitro true dry matter digestibility, ${ }^{7} \mathrm{dNDF} 48=$ proportion of dry matter that is digestible NDF,

${ }^{\mathrm{i}} \mathrm{TDN}=$ total digestible nutrients, ${ }^{9} \mathrm{EE}=$ Ether extract 
Table 4. Heifer descriptive statistics pooled across years.

\begin{tabular}{|c|c|c|c|c|c|c|c|c|c|c|c|c|}
\hline & \multicolumn{4}{|c|}{$\mathrm{HIGH}^{1}$} & \multicolumn{4}{|c|}{$\mathrm{LOW}^{1}$} & \multicolumn{4}{|c|}{ Overall } \\
\hline Trait & Mean & SD & Min & Max & Mean & SD & Min & Max & Mean & SD & Min & Max \\
\hline $\begin{array}{l}\text { Beg. } \\
\text { Age, d }\end{array}$ & 233 & 17.7 & 187 & 271 & 230 & 17.2 & 180 & 272 & 232 & 17.5 & 180 & 272 \\
\hline $\begin{array}{l}\text { Initial } \\
\mathrm{BW}, \mathrm{kg}\end{array}$ & 246 & 28.1 & 161 & 326 & 246 & 29.6 & 160 & 317 & 246 & 28.9 & 160 & 326 \\
\hline $\begin{array}{l}\text { Age at } \\
\text { AI, d }\end{array}$ & 428 & 17.3 & 380 & 464 & 425 & 17.03 & 373 & 465 & 426 & 17.2 & 373 & 465 \\
\hline $\begin{array}{l}\text { BW at } \\
\text { AI, kg }\end{array}$ & 356 & 35.5 & 252 & 463 & 335 & 36.3 & 243 & 421 & 345 & 37.4 & 243 & 463 \\
\hline $\begin{array}{l}\text { Final } \\
\text { BW, kg }\end{array}$ & 415 & 36.0 & 291 & 506 & 403 & 34.2 & 313 & 520 & 409 & 35.7 & 291 & 520 \\
\hline $\begin{array}{l}\text { Beg. Hip } \\
\text { Ht., cm }\end{array}$ & 109 & 4.57 & 100 & 119 & 109 & 4.98 & 102 & 119 & 109 & 4.78 & 100 & 119 \\
\hline $\begin{array}{l}\text { Hip ht. at } \\
\text { AI, cm }\end{array}$ & 123 & 3.30 & 113 & 132 & 121 & 3.45 & 110 & 130 & 122 & 3.48 & 110 & 132 \\
\hline
\end{tabular}

${ }^{1} \mathrm{LO}=$ daily pasture $\mathrm{DM}$ allowance of $3.5 \%$ of $\mathrm{BW}, \mathrm{HI}=$ daily pasture allowance of $7.0 \%$ of $\mathrm{BW}$ 
Figure 8. Heifer ADG for $\mathrm{HI}$ and $\mathrm{LO}$ treatment groups during the fall, winter, spring and summer periods ( $\mathrm{LO}=$ daily pasture $\mathrm{DM}$ allowance of $3.5 \%$ of $\mathrm{BW}, \mathrm{HI}=$ daily pasture allowance of $7.0 \%$ of $\mathrm{BW}$ ).

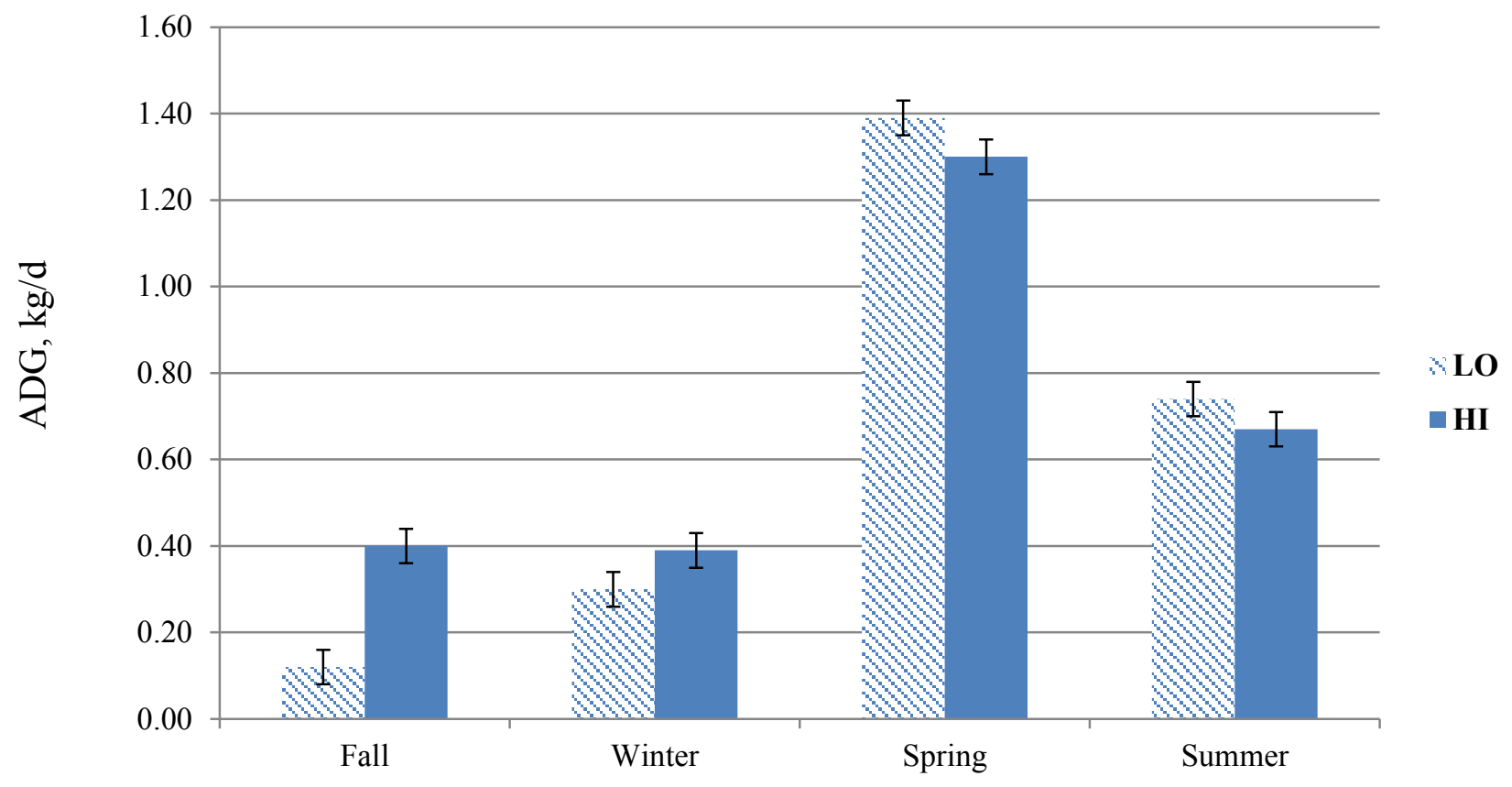


Table 5. The effect of pasture allowance on fertility response to timed AI and subsequent breeding in beef heifers presented by years.

\begin{tabular}{|c|c|c|c|c|c|c|}
\hline \multirow[b]{2}{*}{ Item } & \multicolumn{2}{|c|}{ Year 1} & \multicolumn{2}{|c|}{ Year 2} & \multicolumn{2}{|c|}{ Year 3} \\
\hline & High $^{1}$ & Low $^{1}$ & High $^{1}$ & Low $^{1}$ & High $^{1}$ & Low $^{1}$ \\
\hline Pubertal, \% & 60 & 60 & 28 & 25 & 18 & 20 \\
\hline Pregnant by A.I., \% & 39 & 40 & 34 & 19 & 61 & 41 \\
\hline Pregnant by Bull ${ }^{2}, \%$ & 68 & 57 & 52 & 62 & 54 & 68 \\
\hline Overall Pregnancy Rate, \% & 81 & 74 & 68 & 69 & 82 & 79 \\
\hline
\end{tabular}

${ }^{1} \mathrm{LO}=$ daily pasture $\mathrm{DM}$ allowance of $3.5 \%$ of $\mathrm{BW}, \mathrm{HI}=$ daily pasture allowance of $7.0 \%$ of BW

${ }^{2}$ Expressed as percentage of heifers eligible to become pregnant 